Historic, Archive Document

Do not assume content reflects current scientific knowledge, policies, or practices. 



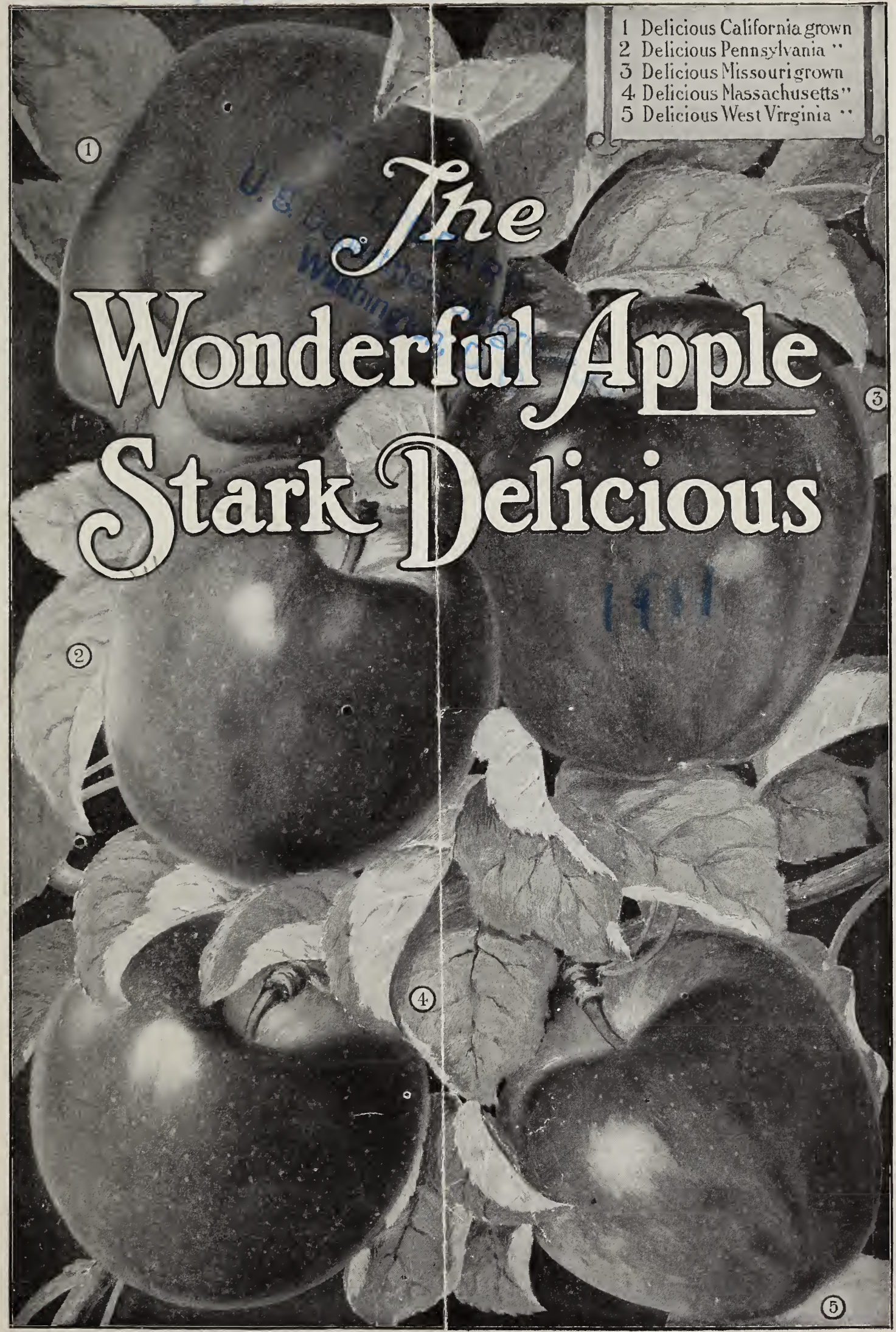

Copyright 1911, by Stark Bro's Nurseries \& Orchards Co. 


\section{This Page is Important to You}

THIS is a booklet full of Good 'Things for everyone to plant this Spring. Every variety has been selected because of special merit either for the home or commercial orchard. Only the best of the very best have been given places in these pages. We can and do recommend every varicty herein listed.

This booklet is not our complete catalog, but is simply a boiled-down selection of the very best things from our complete book-The Stark Year Book for 1911-a copy of which will be sent on receipt of 10 cents to pay postage.

Throughout this booklet varieties under all classes of stock are arranged as nearly as possible according to their season of ripening. Earliest ripening sorts head the lists, while the latest keeping varieties end them. Varieties recommended by us as most valuable for family use or for profit are starred, thus $(*)$.

Following the description of each variety are capital letters which indicate the region in which it is recommended that that variety be planted. N stands for north; NN, far north; NNN, extreme far north; C, central; and S, south. 'Thus a variety followed by NCS may be planted either north, central, or south. CS would indicate a variety adapted only to central or southern planting; NNC, central to far north; NNCS, south to far north; and S, south only.

\section{$25 \%$ Discount to Mail Order Buyers}

will be allowed from the prices quoted herein, for prompt and direct orders-all cash with order.

This price list together with the discount is our personal mail order salesman in your ternitory, and opens the way for every tree planter to secure Stark sterling quality trees at the lowest possible price.

Bear in mind that in addition to this $25 \%$ discount we box free and prepay freight. Also keep before you the fact that we guarantee safe arrival and give liberal premiums.

The pay freight on evrything as priced herein, to any railroad station in the United States and to the U.S. line on shipments to foreign countries on orders of $\$ 10.00$ net or over-cash with order.

We also pay freight on orders amounting to $\$ 10.00$ net or more where one-fourth or more cash is remitted with order, balance to be paid on arrival.

Te Box and Pack Free-bear cost of boxes, bales, moss, fibre, etc. Expensive, but good packing pays-pays customer, pays us.

TVe paper-line all boxes at all seasons-another costly item, but it is a safeguard against both drying out and freezing.

IVe guarantee Safe Arrival-orders lost or spoiled in transit we refill free.

We give 30 trees of one variety at the 100 rate; 300 of a kind (as 300 Apple or 300 Plum, etc., not less than 10 of a variety) at the 1000 rate; over 10 and less than 30 at 10 rate. Less than 10 always at Each rate. Please note where no 1000 rate is quoted that 100 rate governs.

EXAMPLE: In an order for 320 Apples-100 Black Ben XXX, 2-yr., 80 Delicious 3 to $5 \mathrm{ft}$., 1-yr., 120 Delicious XXX, 2-yr. and 20 assorted $(1,2,4,7$, etc., of a sort), latter 20 will go at Each rate, the 300 at 1000 rate.

Different kinds, as 150 Apple and 150 Plum, cannot be taken together to make up 300 so as to obtain 1000 rate.

We guarantee trees true to name, and use every care to avoid mistakes, but should any prove untrue to label we will, upon proper proof, replace the trees free; but are liable no further. Our just and liberal dealing during 86 years is our chief guarantee to customers.

We attach Entomologist's certificates to all shipments. Stark Nurseries have been annually inspected and found free from San Jose scale and other injurious insects and diseases.

We uniformly tie Trees in bundles of 10; Grape Vines and Small Fruits in bundles of 25, and as unbroken bundles are handled at less expense we can thereby offer these unusual concessions.

Three sizes of 2-yr. fruit trees are graded in our packing houses. XXX is the size sure to please. XX size excels "1st-class" of some nurseries. Each size is first class of that size, no second class, defective or cull trees go in any sizc, but to the brush pile.

Our 1-yr. trees are graded into two sizes-3 to $5 \mathrm{ft}$. and 2 to $3 \mathrm{ft}$. Each size full and strong; our 2 to $3 \mathrm{ft}$. size equals the largest 1-yr. of many nurseries.

\section{Stark Bro’s Nurseries \& Orchards Company} Louisiana, Missouri, U. S. A.

Rockport, Illinois

Rolla, Missouri

Fayetteville, Arkansas

Dansville, New York

\section{Branch Nurseries}

Girard, Erie Co., Pennsylvania

Starkdale, Missouri

Marionville, Missouri
Wenatchee, Washington Huntsville, Alabama Portland, New York Twin Falls, Idaho 


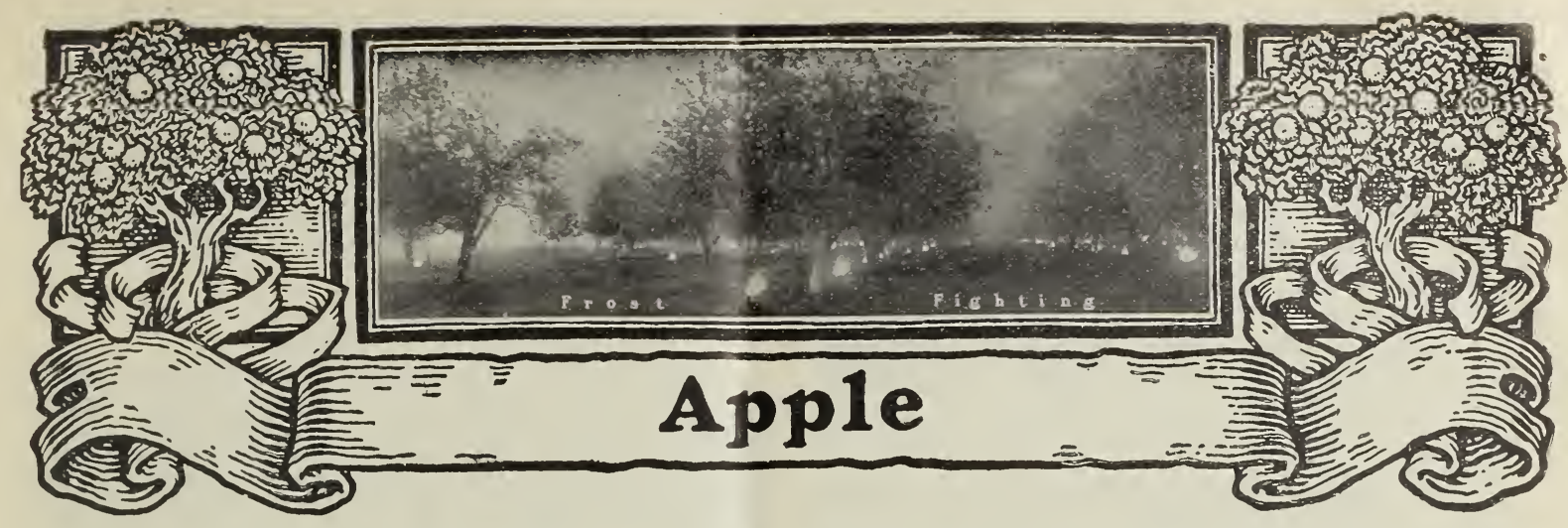

\section{Liveland Raspberry*}

Absolutely the very best red early apple known; of widespread adaptability, remarkable in tree and fruit, and deserving of the most extended planting. Has been tested everywhere; succeeds south as well as far north, in the east and in the west. It is by far the most valuable of the Russians and is surpassingly beautiful; clear waxen white, striped, shaded and marbled with crimson; medium to large; flesh white, often tinged pink next to the skin-very tender and rich. Its exceeding great beauty and splendid quality, combined with its earliness and good size, make it one of the most popular of all early summer apples and very profitable for the orchardist. Fruit ripens just a few days ahead of Yellow Transparent and covers a long season-several weeks. Tree is extremely hardy, healthy, vigorous, and long lived; a late bloomer, resistant to blight and a young bearer. One of the most profitable varieties for planting as a filler. Fruit retains its freshness in storage remarkably well and is a better shipper and keeper than most early apples. The demand for Yellow Transparent will slacken materially when Liveland is planted as extensively as it soon will be planted. Ten trees of Liveland should be planted to every one of Yellow Transparent. Yellow Transparent is a good and popular apple and is deserving of its place but it has a chief fault in its tendency to blight. Growers the country over are beginning to appreciate Liveland and see its possibilities, and the demand for trees is increasing phenomenally. We know of no red early apple anywhere nearly so good as Liveland and we cannot recommend it too highly, nor urge its planting commercially and in every home orchard too insistently. NNNCS

\begin{tabular}{l|c|c|c|c|c|c|c}
\hline \multicolumn{1}{c}{ One Year } \\
\hline \multicolumn{3}{|c|}{3 to 5 feet } \\
\hline Each & 10 & 100 & 1000 & Each & 10 & 100 & 1000 \\
\hline .40 & 3.70 & 32. & 265. & .35 & 3.20 & 27. & 200. \\
\hline
\end{tabular}

Two Year

\begin{tabular}{|c|c|c|c|c|c|c|c|c|c|c|c|}
\hline \multicolumn{4}{|c|}{$\mathrm{XXX}, 5$ to 7 feet } & \multicolumn{4}{|c|}{$\mathrm{XX}, 4$ to 5 feet } & \multicolumn{4}{|c|}{$\mathrm{X}, 3$ to 4 feet } \\
\hline Each & 10 & 100 & 1000 & Each & 10 & 100 & 1000 & Each & 10 & 100 & 1000 \\
\hline .50 & 4.50 & 40. & 330. & 40 & 3.70 & 32. & 265. & .35 & 3.20 & 27. & 200 \\
\hline
\end{tabular}

Liveland Raspberry should be pushed more than it has been. It certainly seems to me that it should take the place of Yellow Transparent as it is one of the most beautifully colored fruits ever placed on the market; quality superior to Yellow Transparent, and as people judge fruits by their color, I think it a valuable variety to grow.-Hon. G. B. BRAcKeTt, U. S. Pomologist. LATER: July 11, 1910. I consider Liveland Raspberry far superior to Yellow Transparent as a commercial variety.

ALABama. I sent you fruit of Liveland Raspberry and Yellow Transparent from adjoining rows. Liveland Raspberry is larger, clear-white fleshed; skin white, streaked with bright carmine. Best early apple.Johv Fraser, Madison County.

ArKansas. Liveland Raspberry ripens with Yellow Transparent and later; tree dwarfish and heavy bearer here, very early bloomer and hardy in bud and bloom, they never twig blight. A splendid cooker.-W. A ELDER, Phillips County.

Delaware. Fruit is rather flat shaped, slightly striped, later than Yellow Transparent. Fine quality to eat out of hand.-W. T. MASsEY, Kent County.

IDAHO. Liveland Raspberry does well here, is a fine fall apple.-N. C. Thompson, Kootenai County.

Iowa. Tree doesn't blight, always perfectly ripened to withstand severe winters. A fine symmetrical grower, heavy, thick leaf; the best early apple I know.-F. O. Harringron, Iowa County.

Montana. Mr. F. G. Pickering, of Carbon County, Montana, sent us some magnificent samples of this variety. We forwarded them to the United States Pomologist, Col. G. B. Brackett, who wrote Mr. Pickering as follows: "A Russian variety of excellent quality, being of much better quality than Red Astrachan and a better commercial variety."
Onio, Yellow Transparent fails to deliver the goods while Liveland Raspberry is loaded with fruit of fine quality.-JоHN COTrLE, Washington County.

OREGon. Liveland Raspberry is extra fine in every way and it seems to me that it is the best in flavor of all the early varieties and is indeed great acquisition.-(Mrs.) Lorenze STILwell, Union County.

RHODE IsLand. Have just fruited Liveland Raspberry. My opinion is that it will be a valuable apple.-ROBERT B. ALMr, Newport County. No early apple East or West is of better quality.-South DAKOta EXPERIMENT STATION.

Tennessee. Liveland Raspberry is a very handsome apple. Am well pleased with the fruit as well as the tree. They are the last tree to bloom in my ninety-acre orchard and of course are less liable to be killed by late frosts.-CHARLES TuCKER, Haywood County.

Wisconsin. Undoubtedly the very best, very early apple knownnot a blighter and hardy as Duchess.-A. CLARK TutTLE, Sauk County.

\section{Wilson Red June*}

Better in quality than Maiden Blush or any Red June, also more valuable for market-a deep red apple of remarkable beauty. Comes in just as Red June goes out and has sold on Kansas City markets at $\$ 16.00$ per standard barrel. As a market apple it is equaled only by Duchess. Tree an exceedingly young and prolific bearer; very vigorous and hardy. Fruit hangs to the tree well and is a splendid keeper for an early apple. Grown in Arkansas they attain the size and wondrous beauty of Black Ben. A very profitable variety for commercial planting in all apple regions; valued highly in Texas. It is much better than Charlamof, surpasses Jefferis, Maiden Blush, Benoni, etc., and is better than Fanny. NCS

Prices, same as Liveland Raspberry on this page.

\section{Jonathan *}

A beautiful, brilliant, dark red apple of very high flavor and excellent quality; tender, spicy, rich and juicy; an A-1 family sort and unusually profitable when planted commercially for the market. It is a seedling of Spitzenburg but of much wider adaptability; originated in New York and succeeds wherever apples can be grown. Tree is an early bearer, long lived and productive, but should be planted with other varieties for cross-pollenation. In the West, Jonathan is the most popular of the older standard varieties and is heavily planted as a filler in orchards of Newtown Pippin and Spitzenburg, and produces several money-making crops before the latter come into bearing. In Missouri, Arkansas, Illinois, Kansas, Iowa, and in many other Middle-Western apple states, where the old worthless Ben Davis was once king, Ben Davis is fast being discarded, old trees are being cleaned out and replanted with Delicious, Jonathan, Grimes Golden, and other varieties of high quality and high commercial value. The business side of orcharding is to-day being given more attention than in the past and as a result, the high quality varieties are in tremendous demand. In southern latitudes, Jonathan is a late fall or early winter apple and is not a long keeper unless put in cold storage; if put in cold storage immediately after picking, it keeps as well as the best keepers known; in fact, it is often kept until apples come again. By many persons unacquainted with Stark Delicious, Jonathan is regarded as the best all-round apple grown. It is a splendid apple, one that will please the grower and make him handsome profits. So strong is our faith in Jonathan, we have grown for the trade of 1911 a full million trees, and it is our firm belief that not one tree will be left unsold. NCS 
Colorado. Jonathan is here in Colorado to stay. Its size, color, good flavor, productiveness and unsurpassed adaptability for cold storage will hold it right up to the front as a winter apple.-WM. Cutrer, SR. Mesa County.

IDAнO. Jonathan is the grandest old apple on earth when scientifically grown. The trouble with most northwest growers is that they leave it hang too long before picking. It is my candid opinion that Jonathan here, though self-fertile should be pollenized by some one of the Bens. That is why ordered Black Ben of you to mix with my new plantings of Jonathan. We have tried many varieties of apples in southwestern Idaho, but Jonathan leads them all.-W. N. Yost, Ada County.

Iowa. Jonathan is the best apple so far as flavor is concerned; for commercial purposes, it is one of the three best and will, when highly colored outsell anything we raise. Its magnificent color, fine peculiar flavor, and good bearing qualities, more than offset its faults. Tree thrifty and long lived; is inclined to overbear in full years when the fruit is off color. The fruit must be handled carefully on account of its tender skin, must be picked as soon as colored and must be kept from premature ripening by promp and effective cold storage. When properly handled, it is a very profitable apple.-H. A. Simons, Fremont County.

Louisiana. One of the very best for early winter, home or market. Brilliant red, only medium size-juicy to the last.-Prof. H. E. VAN DEMaN, Concordia County.

Michigan. Jonathan comes into bearing early, is productive, attractive and of fine quality. Commands highest market prices. One of the best.-Michigan Experiment Station.

Missouri. It will be a long while before the Jonathan will be supplanted in sections where it does well. A great many persons leave it too long before picking. This is particularly the case in our Missouri Rive Valley, also in the lower altitude of the Northwest. Their seasons are longer and the apples get overripe. This is what causes the core rot. I have been eating some New Mexico Jonathan-they certainly are extra fineJames M. Irvine, Editor Fruit Grower.

Montana. Jonathan is a money-maker with me and if properly pruned and thinned will run largely four tier and will keep in an ordinary cellar until March and April, in prime condition.-R. A. Rollins, Flathead County.

Pennsylvania. Jonathan is one of the best apples and should be planted largely. Doing fine here.-JAco B E. Gnager, Somerset County.

Washington. Jonathan is one of the greatest and most profitable varieties grown-is more widely planted in the Wenatchee Valley than any other sort except Winesap. The tree bears very young, bears every year and loads heavily. Some thinning is required when the trees attain age. Their high color and excellent quality make them a favorite on the market.-O. M. Brooks, Chelan County.

Prices, same as Liveland Raspberry. See page 1.

\section{Spitzenburg, Esopus}

Size medium, wholly covered with bright red or faintly striped with darker red and yellow; firm, very crisp, subacid, a strong aroma and a peculiarly pleasing flavor. Special knowledge of this variety is essential to its successful and profitable growing, but under such conditions and in favored localities it is both satisfactory and profitable and should be planted commercially. It is one of the highest car-lot sellers for established trade. Tree tends toward late and shy bearing but can be forced, yet is neither long lived nor generally adaptable; also susceptible to fungus and insects. Profitable chiefly in a few very favored sections of the Pacific Northwest, where experienced growers are finding profit by planting it as a filler in their permanent orchards of Delicious. Also planted in New York and neighboring states. NC

One Year
\begin{tabular}{c|c|c|c||c|c|c|c}
\hline \multicolumn{3}{|c}{3 to 5 feet } \\
\hline Each & 10 & 100 & 1000 & Each & 10 & 100 & 1000 \\
\hline .35 & 3.20 & 27. & 200. & 30. & 2.70 & 23. & 180. \\
\hline
\end{tabular}

Two Year

\begin{tabular}{|c|c|c|c|c|c|c|c|c|c|c|c|}
\hline \multicolumn{4}{|c|}{$\mathrm{XXX}, 5$ to 7 feet } & \multicolumn{4}{|c|}{$\mathrm{XX}, 4$ to 5 feet } & \multicolumn{4}{|c|}{$\mathrm{X}, 3$ to 4 feet } \\
\hline Each & 10 & 100 & & Each & 10 & 100 & & Each & 10 & 100 & 1000 \\
\hline .45 & 4.00 & 35. & 280 . & .35 & 3.20 & 27. & 200. & .30 & 2.70 & 23. & 180. \\
\hline
\end{tabular}

Iрино. Spitzenburg is one of the richest apples grown, and one of the most beautiful, but I find the tree short lived here. It bears early and

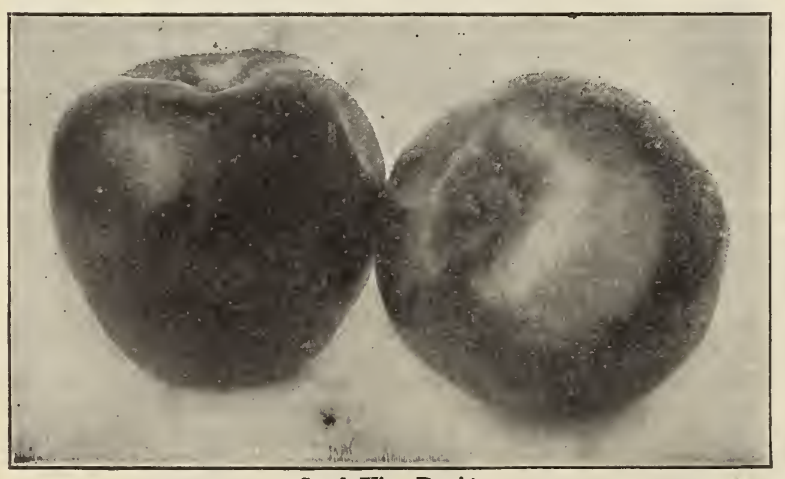

Stark King David heavily, but after the tree gets about twenty years old the apple rots at the core before ripening and in a year or two the tree dies. However, they can be profitably raised, providing a man is satisfied with a fair return on his labor, and is not so stuck on the tree that he is afraid to cut it down and replace it with another.-George A.MAnNing, Nez Perce County.

Wasuingron. Spitzenburg with us will, if properly handled, begin to bear as soon as Jonathan, though not so heavily. I have a block of Stark Delicious planted 36 feet each way and am going to put Spitzenburg in the centcr, pruning for wood the first time, but thereaftcr pruning for fruit. So handled, Spitzenburg is with us a big success. However, Delicious is going to be the most widely planted apple we have ever known and will be successful almost everywhere.-W. B. Armstrong, Yakima County.

\section{Grimes Golden *}

Undoubtedly one of the most popular of the yellow apples, a favorite on all markets and commanding highest prices year after year. A rich, golden, transparent yellow fruit, exceedingly aromatic; size, medium to large, shape somewhat cylindrical, flesh tender, juicy, spicy, and very rich. One of the best eating apples as well as being a splendid cooking apple but, as Dr. Warder says in his authoritative book on the apple, "it is too good for aught else but dessert." The tree is hardy, a vigorous grower, a late bloomer, and a young bearer. For use as a filler it is first class. We recommend this variety without reservation. NCS

One Year
\begin{tabular}{c|c|c|c||c|c|c|c}
\hline \multicolumn{3}{c|}{3 to 5 feet } & \multicolumn{4}{|c|}{2 to 3 feet } \\
\hline Each & 10 & 100 & 1000 & Each & 10 & 100 & 1000 \\
\hline .35 & 3.20 & 27 & 210 & .30 & 2.70 & 2.3 & 180 \\
\hline
\end{tabular}

Two Year

\begin{tabular}{|c|c|c|c|c|c|c|c|c|c|c|c|}
\hline \multicolumn{4}{|c|}{$\mathrm{XXX}, 5$ to 7 feet } & \multicolumn{4}{|c|}{$\mathrm{XX}, 4$ to 5 feet } & \multicolumn{4}{|c|}{$\mathrm{X}, 3$ to 4 feet } \\
\hline Each & 10 & 100 & 1000 & Each & 10 & 100 & 1000 & Each & 10 & 100 & 1000 \\
\hline 50 & 4.50 & 40. & 330. & .40 & 3.70 & 32. & 265. & .35 & 3.20 & 27 & 200. \\
\hline
\end{tabular}

CANADA. Grimes Golden has delighted me, bearing every year and utterly defeating Spy, Greening, Baldwin, King, and Fameuse in amount of crop, while the quality is supreme.-T. C. ORR, Owensound, Canada, in Rural New Yorker.

Colorado. Grimes Golden holds its fruit well without bending the imbs. There is no better apple grown.-JAcoB Heberling, Delta County.

Missouri. Grimes Golden is a wonderful apple for our climate.-T. H. Topd, Howard County.

Montana. Grimes Golden is a success with orchardists who have them here. The fruit has sold with the finest McIntosh-the two varieties selling at 50 per cent above other sorts fruiting here.-J. L. Trurmong, Kalispell County.

\section{Stark $\underset{(\text { Trade-MIark })}{\mathrm{King}}$ David *}

One of the most beautiful apples grown; medium to large, resembling Jonathan in shape, though larger; color, a deep rich red with distinct stripe-like markings of very dark reda blending of the colors of Jonathan and Arkansas Black.

The original tree, in northeastern Arkansas, came up in an orchard of Gano, and at one year was transplanted to a place where a Gano had died. The tree bore the third year. In October, 1902, when Mr. C. M. Stark first saw it, it was then eight years old and was bearing its fifth successive crop-nearly 3 bushels of the most brilliantly beautiful and luscious apples he had ever seen. Grano in the adjoining rows failed entirely two of the five years when King David bore full crop.

The tree and foliage much resembles Jonathan but is far more vigorous and hardy-hardier than Ben Davis. The fruit is also very much like Jonathan but has higher color and even richer flavor and does not drop like Jonathan. In 1902, when Mr. Stark first saw it, the fruit hung perfectly until October 22d, while Jonathan, five weeks earlier (September 15th), where not already gathered, had largely fallen. King David should, however, be picked early (as early as Grimes Golden); if allowed to hang too long the keeping quality is impaired - a fact that is true of most varieties.

Blackman Bro's, successful orchardists of the famous Lake Chelan country of Washington, who have probably had more experience with King David in a commercial way than any other growers in the country, conducted experiments with this variety as to the proper time to pick the fruit. A letter from them, giving us the result of their experiments is reproduced among the letters which follow.

The beauty of King David is unsurpassed by any other apple; its striking appearance commands instant attention and top prices. The tree is healthy, hardy, a vigorous grower, and a remarkably young and heavy bearer, often producing several apples the second year from planting. NNCS 
One Year

\begin{tabular}{c|c|c|c|c|c|c|c}
\hline \multicolumn{3}{c}{3 to 5 feet } & \multicolumn{5}{c}{2 to 3 feet } \\
\hline Each & 10 & 100 & 1000 & Each & 10 & 100 & 1000 \\
\hline 50 & 4.50 & 40 & 330 & .40 & 3.50 & 32 & 265 \\
\hline
\end{tabular}

Two Year

\begin{tabular}{|c|c|c|c|c|c|c|c|c|c|c|c|}
\hline \multicolumn{4}{|c|}{$\mathrm{XXX}, 5$ to 7 feet } & \multicolumn{4}{|c|}{$\mathrm{XX},+$ to 5 feet } & \multicolumn{4}{|c|}{$\mathrm{X}, 3$ to 4 fect } \\
\hline Each & 10 & 100 & 1000 & Each & 10 & 100 & 1000 & Each & 10 & 100 & 1000 \\
\hline .65 & 6.00 & 55. & 450 & .55 & 5.00 & 45. & 380 . & 45 & 400 & 36. & 280 . \\
\hline
\end{tabular}

Arkassas. King David seems to me to be perfection in all that makes a first-class market apple; I could desire nothing better. Delicious deserve its nanie, but I consider King David far in the lead.-Henry T. Williams, ranklin County.

King David is certainly coming up far above my expcctations; remarkably high-colored apple and should sell rcadily on the market, cially on fruit stands where its appearance is so much to recommend itHon. G. B. Brackett, U. S. Ponk !egist.

BRITisi CoLturis. King David and Delicious are in a class by themselves. King David is a little the best in flavor. Previous to this I did not think anything could approach Delicious as to quality, but King David is a marvel in beauty and quality, just right in size for a dessert apple.Rev. George A. Paull, Kootenai County.

CALIForxi.. I have some King David trees, three years old from planting, that are bearing some of the largest, finest apples I ever saw and this is their second crop.-JoHn BeNNetr, San Diego County.

California. King David fruited on a graft put in last March. They are perfect and show what the variety can do in California. Am delighted with it; has a fine vigorous, frost-resisting bloom.-Frank Femmons, Madera County.

CALIFORNIA There have been a good many tons of King David raised here this season, and the people are going wild over them. They don't want anything else but King David. LATER: King David is considered the best fall apple we have here and is in great demand. Here, it keeps until Thanksgiving.-J. F. ANDERson, Tuolumne Cou

ConNECTICUT. I am happy feasting on the apples you sent. Both lots arrived in fine order. Delicious is a little too sweet to be real good eating for me, but say, why did you not get me eating King David before? It sure is good. King David is surely a worthy apple, and if the tree is as good in proportion as the fruit, you are fully justified in pushing it strong. I am tempted to include a few hundred trees of it in my next spring planting.-J. H. HALE, the Peach King.

Florida. King David and Stayman Winesap seem peculiarly adapted to Florida conditions - E. P. Powell, Author Orchard and Fruit Garden. Illuinors. Probably King David as grown in the best sections of Washington, Idaho, and Oregon is the finest in appearance of any apple ever grown. Its skin is a velvety, rich, shiny red, not too dark in color and takes a polish beyond that of any other variety known to-day. In good size; in flavor, more acid than Stark Delicious or Grimes, but les acid than Jonathan or Spitzenburg. The best judges consider it a strictly good flavored apple, but not up to either Jonathan, Grimes, Spitzenburg, or Delicious. It might rank with Stayman Winesap, although entirely dif ferent. It is a valuable late fall or early winter variety.-BEN. NEwHALL, Chicago.

Indiana. King David bore this season for the first time. Fruit is fine-finer and later than Jonathan.-J. F. Grass \& Son, Perry County.

Iowa. I am of the opinion that you have not told half the good points concerning King David. I am sure it is to be the one great money-make for growers in certain sections, on the whole the second best apple in al America, Delicious first, of course-Thos. F. Rigg, Iowa Experimen Station.

IowA. Some years ago you sent me several varieties for testing; last season some of them fruited. King David was simply fine and the tree was full. Other varieties were damaged by the early freeze.-C. A. CAMPBELL Van Buren County.

Kavsas. King David is large, oblong, dark red, smooth in outline full or nearly so at the blossom end, a fine shape and size. Quality too good to tell.-A. H. Griesa, Douglas County.

KentuCKY. My King David trees are growing fine. They outgrew all the others; sorry I did not get one hundred instead of ten.-T. P. STOREY Meade County.

Massaciusetrs. On the market at Brockton, I found some of the handsomest apples I ever saw-King David. They bring 10 cents "each.H. W. ManN, Norfolk County.

Missouri. Nothing can beat King David-it easily is king of the Winesap family, but all Winesaps arc at home in Missouri. King David is Winesap family, but all Winesaps arc at home in Missouri. King David is

Missouri. I Have a number of varieties of apples, but Black Ben and King David outgrow the others two to one. For high rocky land give me Black Ben and King David.-Ernest Hawrins, Newton County

New Jerser. King David trees bore some magnificent apples last year (1908). Both King David and Delicious in our sandy soil of northern New Jersey have made a fine growth.-Bernard O. Bogert, Bergen County. New Mexico. King David is far above the usual kinds and qualities - better than Jonathan as a table apple. Can be eaten by people with delicate stomachs and are better and better the longer one eats.-HoN. PARKER EARLE, Ex-President American Horticultural Society.

OzEGov. King David makes apples like Champion, Winterstein and Wismer Dessert look pretty cheap. I predict a great future for it.-F. L. Phelps, Umatilla County.

UTAн. Two terrible wind storms whipped off half the apple crop here, but from my three hundred King David I only found one apple blown off. The wind can't budge them. Tree a vigorous grower, hardy, and woo does not split, is tcugh and strong, comes into bearing early. King David is a dandy for this place. It is all you claim and more too. This orchard is at an altitude of 6,100 feet.-J. C. Lemon, Emery County.

UтAн. I have King David and consider them first class in size, color and flavor.-EDward Parks, Weber County.

Virginia. King David made a very fine appearance at the Winchester, Virginia, Show, and I am looking forward with considerable interest to the maturing of this variety, so that I may have a chance to sample its flesh flavor.-E. R. LAKE, Expert in Pomological Nomenclature, U. S. Department of Agriculture, Washington, D. C.

VIRGINIA. I have sent you two apples which grew on some four-yearold trees. Our apple men here can't tell me what variety they are.-J. W.
Mrers, Frederick County. (Note: Specimens sent by Mr. Myers were King David. The quality was as fine or finer than in western-grown specimens, and the flesh was firm, juicy, spicy, and good.-STARK Bro's.) WAsmington. I have King David that would knock the spots of of circumferencc. They hang as well as old IVinem measurew of them have fallen and we have had many, very heavy wind storms this summer-a and fruit, have done fine.-G. T. Goundrex, Douglas County.

Wasmington. King David is the first apple to color up-a good Wasmington. King David is the first apple to color up-a good
point. It colors evenly throughout the tree, away from as well as to the point. It colors evenly throughout the tree, away from as well as to the
sun. It distributes itself evenly over the branches, does not cluster, and so far as my present observation goes, is the finest thing yet. As a Christmas apple for

WAshington. I consider King David far ahead of Jonathan, the fruit is larger, has better color and flavor and is a better keeper. I met one man here top-working his King David. IJe told me his reason was on account of them being badly water-cored, which made me a little afraid to recommend the variety. I told a Mr. Olds (an experienced orchardist here) about the matter and he took me into his cellar and we picked out apples that could make any apple in the valley water core by using too much water when the fruit was grown.-D. J. II A w DEN, Chelan County.

WASHINGTON. There was so much talk about the keeping quality of King David that we experimented with it last year. We picked the first lot on September 22d, the next lot two weeks later, and another lot still two weeks later. All three lots were put in a common cellar. In March we returned and upon examination found those picked on September 22d all perfect; those picked two weeks later were about one-half good while those picked last were all gone with rot. This experience shows us that certainly are beautiful.-BLACKMAN Bro's, Chelan County.

WAshington. For flavor and beauty, King David cannot be excelled. My trees are well loaded, in fact, some of them are entirely too full. I did My trees are well loaded, in fact, some of them are entirely too full. I did County.

\section{York Imperial *}

Greenish-yellow, nearly covered with bright red. Flesh crisp, firm, sub-acid, and good, but not of highest quality-a good keeper and retains its flavor to the last. Has been tested everywhere-in the East, West, and South it is one of the best, but is not quite hardy far north, though it succeeds well in southern Iowa. An annual bearer; tree vigorous, long lived, and popular in all orchard regions. A splendid keeper for home use, but for cold storage requires special care to prevent scalding and should be gathered only after becoming highly colored and well matured. Will not fill barrels quite as fast as Stayman Winesap and Black Ben, yet should go in every orchard. Sells readily at fancy prices on the English markets as a Red Newtown. NCS

Prices, same as Liveland Raspberry. See page 1.

VIRginia. In the valleys and in northern Virginia generally, York Imperial, perhaps, heads the list for commercial planting of anything that is well known.-Prof. H. P. Gould, U. S. Department of Agriculture, is well known.- Prof. H. P. Gould, U. S. Department of Agriculture, perial orchard averaged 10 bushels to the tree, selling at $\$ 3.00$ per barrel on the tree.-STARK Bro's.)

Virginia. Three-fourths of my orchards are York Imperial, the best money-maker we have for this section of the valley.-W. L. BRYAN, Rockbridge County.

Washington. One orchard near Monitor, Washington, will always remain in my vision. York Imperial trees looked more like great grape vines-limbs borne to the ground, so the trunk could hardly be seen. If I had been told a tree could exist under such a load, it would have been hard to believe. The owner showed me one tree which he said would return him $\$ 90.00$, and that they would average $\$ 75.00$ each. -T. H. ATkinson, Chelan County.

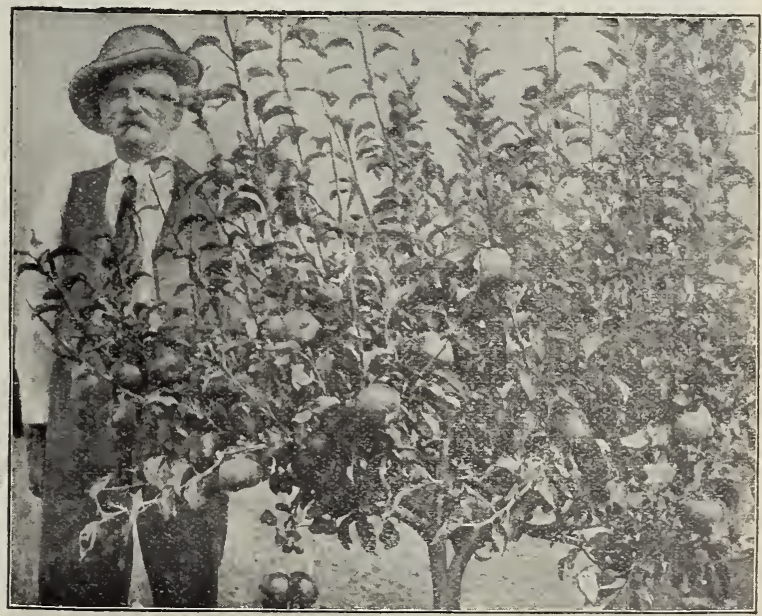

A Stark King David tree, three years from planting, bearing its second crop 


\section{Stayman Winesap *}

Where an apple of the Wincsap family is to be planted we urge orchardists to select Stayman Winesap to the exclusion of all others. We have worked with and tested this variety very carefully, have watched it come into more popular favor cach year and we know it to be the best of the valuablc Wincsaps. Stayman originated in Kansas with the late Dr. J. Stayman and is a seedling of Wincsap. Color, a dark, rich red, indistinctly striped but in specimens less highly colored the striping is more pronounced. Flesh is firm, very finc grained, crisp, excecdingly juicy, rich and tender, and the quality is best. Tree is a stronger grower than Winesap, a resister of drouth and will thrive on thin soils on which the old Wincsap would soon starve. It is a more regular bearer than Winesap, hangs longer, keeps as well and in quality is far supcrior. Writing us some 14 ycars ago, and while mentioning the excellence of this apple, the originator said, "There will come a time when all will want it." Dr. Stayman was quite right; of all the apples we know, with the exception of Delicious and King David, no other is being more largely planted or coming into more widespread favor than is Stayman Winesap. We urge planters to grow it-it will not fail to pleasc or to pay handsomely. NCS

One Year

\begin{tabular}{c|c|c|c||c|c|c|c}
\hline \multicolumn{3}{c||}{3 to 5 feet } & \multicolumn{4}{|c}{2 to 3 feet } \\
\hline Each & 10 & 100 & 1000 & Each & 10 & 100 & 1000 \\
\hline 4.0 & 3.70 & 32 & 265. & .35 & 3.20 & 27. & 200. \\
\hline
\end{tabular}

Two Year

\begin{tabular}{|c|c|c|c|c|c|c|c|c|c|c|c|}
\hline \multicolumn{4}{|c|}{$\mathrm{XXX}, 5$ to $7 \mathrm{fcct}$} & \multicolumn{4}{|c|}{$\mathrm{XX}, 4$ to 5 feet } & \multicolumn{4}{|c|}{$\mathrm{X}, 3$ to 4 feet } \\
\hline Each & 10 & 100 & 1000 & Each & 10 & 100 & 1000 & Each & 10 & 100 & 1000 \\
\hline 55 & 5.00 & 45. & 400 . & .45 & 4.00 & 35. & 280. & .35 & 3.00 & 27. & 200. \\
\hline
\end{tabular}

The Stayman Winesap specimens you sent me were the finest ever received at this office, and the finest I ever saw. I have had a painting made of one of the specimens and at my earliest convenience will have a copy of it made to send you. Wenatchee Valley can certainly grow Stayman to perfection.-HoN. G. B. Bracketr, U. S. Pomologist.

Stayman Winesap is a grand apple. It makes a handsome showy apple in the West but is an apple of much higher quality relatively when grown in the humid eastern sections. It is particularly fine right in the old Winesap districts and in the tide-water section of Virginia and Maryland, and adjacent states where it is not so easy to get high quality winter apples.-M. D. WAITE, Pathologist in Chicago, U. S. Department of Agriculture.

Arkansas. Stayman follows close to Delicious in quality, bears regular and heavy; tree makes strong and healthy growth. Sold some Stayman at $\$ 5.00$ per bushel, f. o. b. station.-H. D. Morton, Pope County.

IрAно. Stayman Winesap ranks among the best commercial apples; it is attractive in appearance, rich in flavor, a good keeper, and of nice even size for packing. The tree is very productive-George A. MANNing, Nez Perce County.

IowA. Stayman Winesap, though growing in several kinds of soil, are uniformly fine growers wherever they are. Wherever tested, East or West, the report is always good. Such experts in truit-growlng as J. W. Kerr, of Maryland and others, consider it the most promising apple for commercial planting in the East.-Iowa Horticultural Societr Report.

Iow A. Am highly pleased with the quality of Stayman Winesap; my people voted it equal to Jonathan. It is a longer keeper-some being on hand until late in May. The trees in my orchard, which are alternated with Ben Davis, show as much precocity in bearing as do the Ben Davis trees. I am more strongly confirmed in my opinion from this year's observation, of the value of Stayman Winesap for either home orchards or commercia planting.-F. O. Harringron, Iowa Experiment Station 1906.

Kansas. The five bundred Stayman Winesap purchased of you six years ago are doing fine. Apples from these trees took both first and secon prizes at the Wichita Fair this season-twenty-one apples weighed twentyfive and one-half pounds.-F. R SMrTh, Sedgwick County.

Maryland. Stayman Winesap is by far the most popular winter variety with us.-C. P. Close, State Horticulturist, Maryland.

Maryland. Medium to very large, oblate conic to oblong conic, often dull red, but sometimes red splashed and mottled toward blossom end only. Flesh crisp, juicy, excellent. Trees from the nursery come into bearing young and are productive of even sized fruit, but top-worked trees are likely to produce fruit uneven in size for the first few years. This will undoubtedly be the leading winter variety in Maryland except in the western part of the state-M - M

Missoori. Am much pleased with Stayman Winesap and want another block of them this spring. A fine, strong, healthy tree, with frostproof blos soms. A fine flavored big apple and an excellent keeper. I wish my whole orchard were Delicious, Stayman Winesap and a few Jonathan. I would hardly look for a crop failure then and I am sure the market would be hunting me. -C. M. Fetre, Vice-President Mississippi Valley Apple Growers' Congress.

Nebraska. Stayman Winesap is a good apple of large size; tree very hardy and prolific and quality of fruit very high. It is all that Dr. Stayman claimed for it.-B. F. CARROLL, Lancaster County.

OHIо. Stayman Winesap is a fine grower, of fine quality and is one of our favorites. It makes a fine running mate for Delicious.-JoHN CorTLE, Washington County.

Oregon. From what I know about the Winesaps I would plant nothing but Stayman Winesap. To my idea that is a grand sort in every way.(Mrs.) Lorenzo Stilwell, Union County.

Pennsylvania. Stayman is a grand apple, far ahead of old Winesap.Wr. Wetr, Clearfield County.

Rhode Island. Stayman Winesap is great; does well in this section. Six-year-old trees bore a barrel each. Crisp, tender, juicy-a splendid apple.-Robert B. Almy, Newport County.

Tennessee. Stayman succeeds well here, is large, symmetrical, has good color and is one of the finest in quality. Has proven to be more resistant to frost than Arkansas Black and some others when in bloom. Does not hold its fruit quite as late as Winesap, but unlike the latter does not scab. In size and keeping quality, it is similar to Ben Davis.-Landon Arres, Green Co.

Virginis. This season in the Waynesville orchard Stayman Winesap was well colored and made up nicely - had an elegant finish. These growers are very favorably impressed with it. Bears at a comparatively early age.H. P. GouLD, before Virginia Horticultural Society.

Washington. Stayman Winesap has made rapid advances in the favor of the growers of this section in the last few years. It is of higher quality than the old Winesap, the trees are thriftier, bear younger, and are more prolific. The apples are sometimes too large on young trees, but with age they come down to commercial size. On the other hand they require age they come down to commercial size. On the other hand, they require
little or no thinning, as is the case with old Winesap. The fruit is well distributed all over the tree, and the tough fiber of the wood enables it to carry a tremendous load. Stayman is a winner.-O. M. Brooks, Chelan County.

Washington. Stayman is becoming about the most popular apple here. Old Winesap men are becoming converted every day.-T. H. AxkINson, Chelan County.
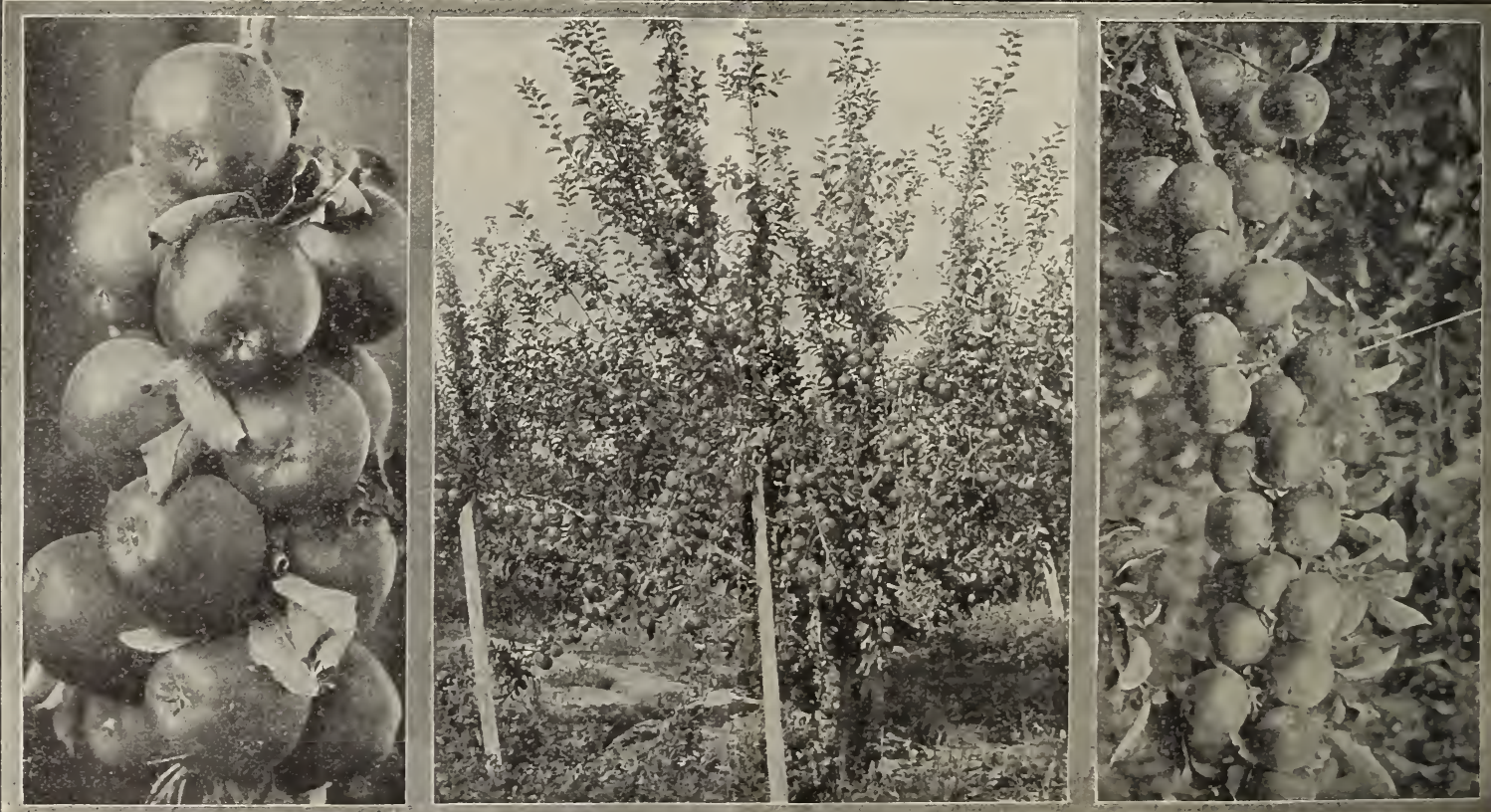


\title{
The Wonderful Apple Stark Delicious
}

\author{
"It is a gem-the finest apple in all the world." \\ - Luther Burbank.
}

Distinctive in shape, beautiful in color, remarkable in quality and perfect in tree and blossom, Stark Delicious stands so apart from all other apples as to make the writing of a description, doing it full justice, an almost impossible task. The Hon. Luther Burbank, known to all for his pomological genius, describes it simply-"It is a gem-the finest apple in all the world."

Stark Delicious is large, with the surface almost covered with a most beautiful, brilliant dark red, blending to a golden yellow at the blossom end. The calyx, or blossom end of Delicious, is one of its ever-characteristic features-having five protuberances more or less pointed or flat-rounded, depending on the section where grown.

In quality it is unsurpassed, incomparable-words cannot describe it. In flavor it is sweet, slightly touched with acid but only enough so to make it all the more pleasing, with an aroma delightfully fragrant. The flesh is fine grained, very crisp, exceedingly juicy and melting, and withal, delicious. People with delicate stomachs, to whom an acid apple is wholly indigestible, find Delicious the one apple they can enjoy without disagreeable after-results. Physicians of note have prescribed it for cases of this character.

In keeping qualities it ranks with the best, coming out of storage in March and April in perfect condition.

In tree Delicious is tree-perfection and one of the strongest, hardiest, and most vigorous growers among apples; aphisresistant, and a late bloomer; blossoms strongly frost-resistant - a most important and valuable feature.

Delicious was originated at Peru, Madison County, Iowa (near Des Moines), by the late Mr. Jesse Hiatt, and on his farm the original tree still flourishes, bearing annual crops of as beautiful fruit of this variety as we have ever seen.

In 1895 we undertook the propagation and introduction of Delicious, purchasing outright from Mr. Hiatt the sole right to it. In writing us at that time, the originator included in his letter a description and history of the original tree, which we reprint since it is representative of the tree as it is grown in all parts of the country:

"The original tree of Delicious is now about fifteen years old and is 13 inches in diameter at ground. Makes strong, vigorous grower, similar to Winesap, except branches are stronger and need little or no pruning. Both tree and fruit are perfect models. The tree is strong, has finely molded limbs which are adapted to bearing great weights of fruit. Does not sprout or sucker-does not succumb to blight, and has never shown signs of tenderness. During the last eight years drouth and cold have killed three-fifths of my orchard, but Delicious withstood it. Bears annually, yielding large quantities of luscious fruit, both beautiful and delicious. Praised by all who have tasted it. Has a peculiar quality that cannot be surpassed nor described and a delicious fragrance. Brilliant dark red, often mingled with gold near blossom end. Splendid winter keeper, equal to Ben Davis. All declare it to be the best apple in the world."

In the same letter Mr. Hiatt describes the fruit, saying: "I am nearly seventy years old, and have raised apples all my life, and would not willingly overestimate Delicious for forty such varieties, but if it is not a better apple than any of your large list, it will cost you nothing. I have never seen a man taste it but who says it is the best apple he ever sampled. It hangs on the tree as well as Ben Davis, keeps as well, is a good shipper (bruises, instead of decaying, dry up, like Ben Davis), is as large, of finer color, as strong a grower, hardier, bears as young and every year. Once introduced, there will be but little call for Jonathan."

It goes without saying that before undertaking the propagation of this variety we carefully investigated its merits. That we are pushing and urging its planting as ardently and as persistently as we are doing, is proof that the results of our investigations were wholly satisfactory. We unhesitatingly recommend Delicious for any purpose and for any locality where an apple tree will grow.
No other apple has ever commanded or deserved a onehundredth part of the enthusiasm, attention, and praise that has been showered on Delicious by everyone who has seen or tasted it-orchardists, horticulturists, commission men, and the great apple-consuming public, have, one and all, lauded it to the echo.

On the markets - "the court of last resort"-Delicious has, season after season, recorded triumphs never before equaled in the history of fruit selling. Prices undreamed of it commands, with the demand always far ahead of the supply, while old favorites believed to be firmly seated on the top step of popularity, have fallen into a second place.

Perhaps no other variety ever won esteem and popularity among commercial orchardists as quickly as did Deliciousattributable to the exceptional qualities of the tree and the unusually large profits the fruit earns. Especially is this true in those wonderful orchard regions lying west of the Colorado Rockies and extending to the Pacific Coast. In those regions Delicious has earned almost unbelievably large profitswhich if printed into book form would be well named - "Delicious, the Modern Aladdin's Lamp." Many records of what Delicious has done and is doing in a profit-earning way are related in the letters from orchardists which we are reproducing.

No apple in propagation shows such wonderful adaptability; from all regions comes the same story. On the cold, bleak prairies of Iowa where it originated it is at its best; in Michigan it is pronounced perfection, crowding out Spy and Baldwin; in Nebraska and South Dakota, in the far westWashington, Oregon, Idaho, Wyoming, Colorado-it stands at the very top of the list, and even in the Bellflower country of California it has made good; in New Mexico its wondrous beauty is a revelation. In Montana it is outstripping McIntosh and bringing double the price. In the fruit belts of Missouri, Arkansas, Pennsylvania, New York, and all New England, it is fruiting to perfection; in Virginia and West Virginia, where orchardists are just beginning to awaken to their country's wonderful possibilities, and in Tennessee, Delicious is repeating its unfailing fruiting record. Even far south, where so many varieties are failures, it thrives. In Australia and New Zealand it is one of the few varieties that can be grown without double-working, because of its aphisresistant qualities. You will search all pomological history in vain for an apple anywhere nearly approaching the record of the great Stark Delicious-and the half has not been told.

We have handled thousands of boxes of Delicious since its introduction; we have handled at the same time many other varieties-the best keepers and the best sellers of the older sorts, but Delicious is by far the most satisfactory. During the last few years we have shipped them to every corner of the United States, and to many foreign countries, and we firmly believe its splendid keeping and shipping qualities, together with its wondrous beauty and its incomparable quality, will make it the export apple of the future. As a shipper it is perfection. We offer other good varieties-apples of splendid quality, good keepers, good shippers, sorts that are popular; but when a planter asks for the best we name Delicious - then more Delicious.

Plant Delicious largely, make it the largest block in your orchard, and you will never regret it. NNCS

One Year

\begin{tabular}{c|c|c|c||c|c|c|c}
\hline \multicolumn{5}{|c||}{3 to 5 feet } & \multicolumn{4}{|c}{2 to 3 feet } \\
\hline Each & 10 & 100 & 1000 & Each & 10 & 100 & 1000 \\
\hline .45 & 4.00 & 35 & 280. & .35 & 3.00 & 27. & 200. \\
\hline
\end{tabular}

Two Year

\begin{tabular}{|c|c|c|c|c|c|c|c|c|c|c|c|}
\hline \multicolumn{4}{|c|}{$\mathrm{XXX}, 5$ to 7 feet } & \multicolumn{4}{|c|}{$\mathrm{XX}, 4$ to 5 feet } & \multicolumn{4}{|c|}{$\mathrm{X}, 3$ to 4 feet } \\
\hline Each & 10 & 100 & 1000 & Each & 10 & 100 & 1000 & Each & 10 & 100 & 1000 \\
\hline 60 & 5.50 & 50. & 400 & .50 & 4.50 & 40 & 330 & .40 & 3.70 & 32. & 265. \\
\hline
\end{tabular}

ARKansas. I have one hundred bearing trees of Delicious. I conside it the finest quality apple grown, followed closely by Stayman in its season. It is a heavy and regular bearer. My trees are nine years old and have borne four crops. Have plenty of Delicinms weighing 12 ounces, some 14 


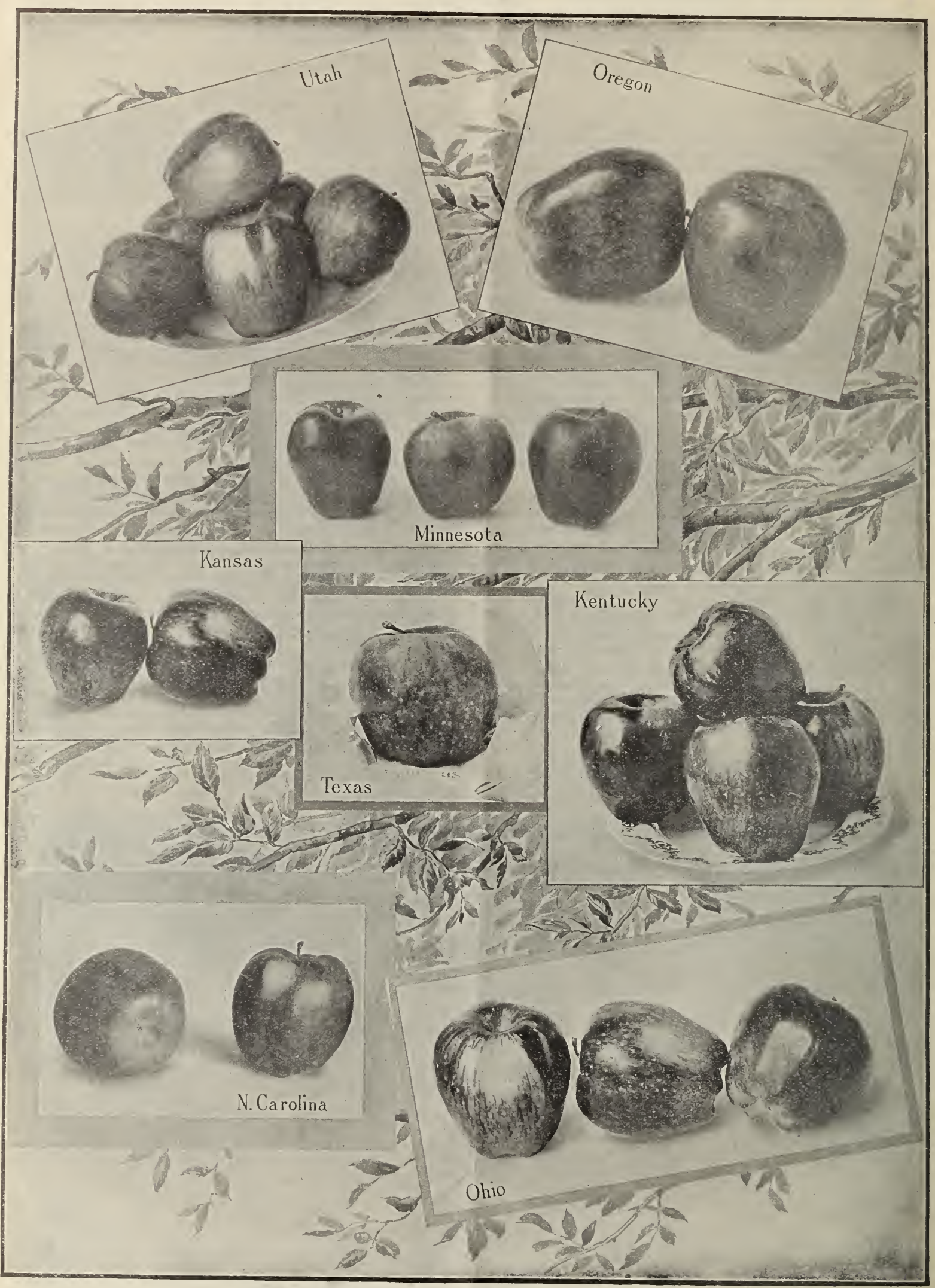


and 16. I consider it the best money-maker and Stayman next. I get $\$ 2.60$ for Delicious from the trees. Nothing stood last year's drouth better than Delicious. Ingram and Champion have been good also.-H. D. Morton, Pope County.

ArKansas. I consider the Delicious the finest apple in the world. I have raised them that beat your pictures of them.-J. R, GraY, Yell County Arizova. I have one Delicious tree in bearing. Was top grafted fou years ago and has borne two crops of very fine apples.-W. A. Jordax Yavapai County.

CAliforia. The Delicious is the best apple $\mathbf{I}$ ever ate. The tree a strong, vigorous grower; ten third-size one-year trees that I planted spring 1906 now (1910) stand 15 or more feet high, and are 5 and 6 inches
in diameter at collar. Ilad about a box and a half of apples on last fall.Robert Clifford, San Diego County.

California. The Delicious kceps about as long as any we have and longer than any other good apple.-LUther BUrbank, Sonoma County.

California. Delicious, King David, Paragon and Stayman Winesap, have a fine, vigorous, frost-resisting bloom. They have escaped when many others were entircly killed. Have thought them about equally hardy, but this year, one of the severest I have ever known, Delicious proved its superiority; a fair crop on all trees with temperature at 26 degrees at blooming time. King David and Stayman Winesap also have a fair crop but not so good as Delicious. The fact that an apple has hardiness of bloom to
resist 3 to 6 degrces more of frost is of far greater importance than the time of blooming.-Frank Femmons, Madera County.

Calfornia. I mailed you to-day a sample of the Delicious apple grown on your yearling trees two years from planting. I had two on onc little tree. How does it compare with samples from other states? I had no doubt but what those highly colored plates in the Year Book exaggerated the apple, but all doubt is now removed. I don't think the plates nor the the apple, but all doubt is now removed. I don't think the plates nor the premium picture does this one justice. I had them on exhibition at the store
and they were the admiration of everybody. Their rich color and beauty and they were the admiration of everybody. Their rich color and bea

CAlifornia. From my two years of experience with Delicious, I find them superior to anything I have so far planted. They seem to be almost wholly resistant to powdery mildew, which has been more or less of a menace or absolute injury to many other varieties of my growing stock. They are fairly drouth resistant, thriving where some of the other stock will take on the appearance of a decided set-back. For general all-round thrift and rapid growth, I do not find that they have an equal among the different
varieties I have so far tested on my place, which is, as far as I know, the varieties I have so far tested on my place, which is, as far as 1 know, the an altitude of more than 6,250 feet.-S. B. WRIGHT, San Bernardino County. Colorado. I cannot say enough in favor of Delicious. It is an apple of exceedingly fine flavor, handsome appearance, and I know from experience that its keeping qualities are good.-M. A. SHUTE, Secretary Colorado Horticultural Society.

Colorado. My Delicious trees are eleven years old from setting. I find that the tree is a strong, upright grower, very clean and healthy. They are easily the leader of all known apples, and to my notion attain their greatest perfection in this mountain region. I arrived at this conclusion on comparing them with Delicious of other states as shown at the Denver National Apple Show. Their keeping qualities are as good as the best when kept in a common cellar not too cold-36 degrees is about right.-C. H. CoE, Garfield County.

Color.do. I have twenty-five Delicious apple trees in bearing, have borne every season for five years. Have sold all I had at $\$ 3.00$ per box when Jonathan were selling at $\$ 1.50$. No apple in existence equals it in quality. Gos Wetzes, Garfield County.

Colorado. Our experience with the Stark Delicious has been that it is a very desirable apple for its season. I consider it one of the best flavored and highest quality apples we have in Colorado.-E. R. BENnET, Larimer County.

Colorado. Have found a tree here bearing on top grafts put in 6 or 7 years ago, from which the owner, Mr. C. G. Smith, picked fourteen boxes this year. They are far superior to the samples you sent me, solid red with very year. They are far superior to the samples you sent me, solid red with very pronounced yellow dots, with the five little protuberances at the calyx claim for it.-George La Grange, Mesa County.

Colorado. No man can make a mistake in planting Delicious, it is far superior to any apple I have ever tested, is hardy and a good keeper. A man with a Delicious orchard can control his own price. A bearing orchard of Delicious would not be for sale at any price.-Hon. WM. Cutrer, Mesa County.

Colorado. I have about one hundred boxes of Delicious. Took the prize at the State Fair at Pueblo also at Cortez-very fine and good.-WM. C. Mrller, Montezuma County.
Colorado. The Delicious trees in Mr. B. F. Bowers' orchard have made a fine growth and were loaded with apples of the finest quality. Mr. Stoward, President of the Nurserymen's Association, says their color is finer here than he has ever seen elsewhere and the size and flavor compares with the best. The trees, although but seven years old, were a picture this year, loaded to the ground with the choicest fruit.-JoHs HARBErT, Otero County loaded to the grou

ConNecticut. While $I$ appreciate your kindness in sending me a box of Delicious apples, I did not need them to convince me of its good qualities as $I$ have seen it in the West and here in the East. The samples I have heretofore seen in the East were not of very good size, but specimens in our own orchard at Seymour this year came up smiling in good shape. Come right
down to daily feed, I find the Delicious fills the bill better than King David. 一J. H. II ALE, the Peach King.

Connecricut. We exhibited Delicious at our recent fruit show of the State Society. With us the variety is very promising both in growth and crop. They also kept fine last year.-A. G. GuLLEx, Tolland County. Fair, and Delicious charge of the Iowa Fruit Exhibit at the St. Louis World's ton, of Iowa, took first prize for quality over all competitors. In Iowa it is ton, of Iowa, took first prize for quality over all competitors. In Iowa it is
easily king of all apples in quality, grows well, bears well, and excites more admiration than any apple ever produced. Delicious has come to stay. Have seen the variety in many states and know it as a strong grower, very productive, a good keeper, and sells higher on the market than any variety $\$ 3.00$ wn. I have engaged all the apples on two trees here for next fall at Silas Wrison, Canyon County.

IDAно. We are usually very ready to "kick" if the trees, etc., don't grow, so it is only fair to tell the other side when they do grow. Out of three hundred Delicious apple trees I bought of you last winter and planted about May 1st, near Jerome, Idaho, we have lost only one tree, the balance will average 24 -inch growth in ninety days-strong and vigorous. We consider the result great for green hands right out of Chicago, who never grew

IDAHO. The Delicious has been grown as an experiment on this tract and its value for this part of the Snake River Valley seems to have been fully demonstrated. The specimen I received, grown 25 miles north of us was perfect. There is a great deal of interest about this variety and a good many new orchards will be planted to Delicious in the next few years. Paul Ellis, Bingham County.

ILLINoIs. The only mistake I made in planting your good Delicious apple was in not planting at least one thousand trees; they are better than you ever claimed them to be-the finest eating apple man or woman ever tasted. Could have sold one thousand boxes of them this year at or above fancy prices. I do not believe the market will ever be overstocked with your leader of the world-Delicious. There is none better, simply perfect-you have found it. Tree a splendid grower, very fine wood and shapely headand at this time, December 10 , has most of its foliage still hanging, while all others are defoliated entirely.-HenRY C. CUPP, Adams County.

InLrNors. Stark Delicious has attracted more attention from fruit critics than any other in the past three years. It has without doubt sold at an average price higher than any other apple grown. Often compared with Spitzenburg, Jonathan, and Grimes Golden, but it is hard to compare Stark Delicious with any apple. True, tastes change; so who shall decide unless it be the people who pay for them. But Stark Delicious has been before the public long enough to have its weak points found before this-if it has any. One thing seems certain, the taste for sweet and semi-sweet apples is growing, and Stark Delicious seems to combine the sub-acid quality with richness of flavor in the highest degree. Some find fault with its ribbed nature at the blossom end; I consider this an advantage - it adds distinction to the apple.-Ben Newhall, Chicago.

IlliNoIs. Last evening the finest box of apples I ever saw arrived at our house. I have seen some pretty fine Delicious in the last $t$ wo years, but for style and color and perfection of shape, I believe this box is unmatched. You are spoiling us for any other apples-getting so we cannot eat an ordinou are spoling us for any other apples-getting so we cannot eat an ordinary fancy Spitz, or Grimes, or Jonathan or Wealthy. The friends that
come to our house fairly stare at them. They cannot understand such come to our house fairly stare at them. They cannot understand such
quality. Delicious is worth all the time and thought and work you have put on it-yes more.-Ben Newhall, Chicago.

ILlinois. We had good luck with Delicious last year and believe it will prove more of a winner than ever.-L. G. KUnZE, Fancy Fruit-Dealer, Chicago. Illinors. I happened to be in the store of Stanton \& Co. here, who make a specialty of supplying the highest-grade fruits, and I asked them if they handled Delicious. They said they did and that they paid $\$ 9.00$ per box for them, and would be glad to pay $\$ 12.00$ if they could get them now. They said Delicious is the finest apple grown and that they could
sell a great many more of them if they had them. Of course, that kind of

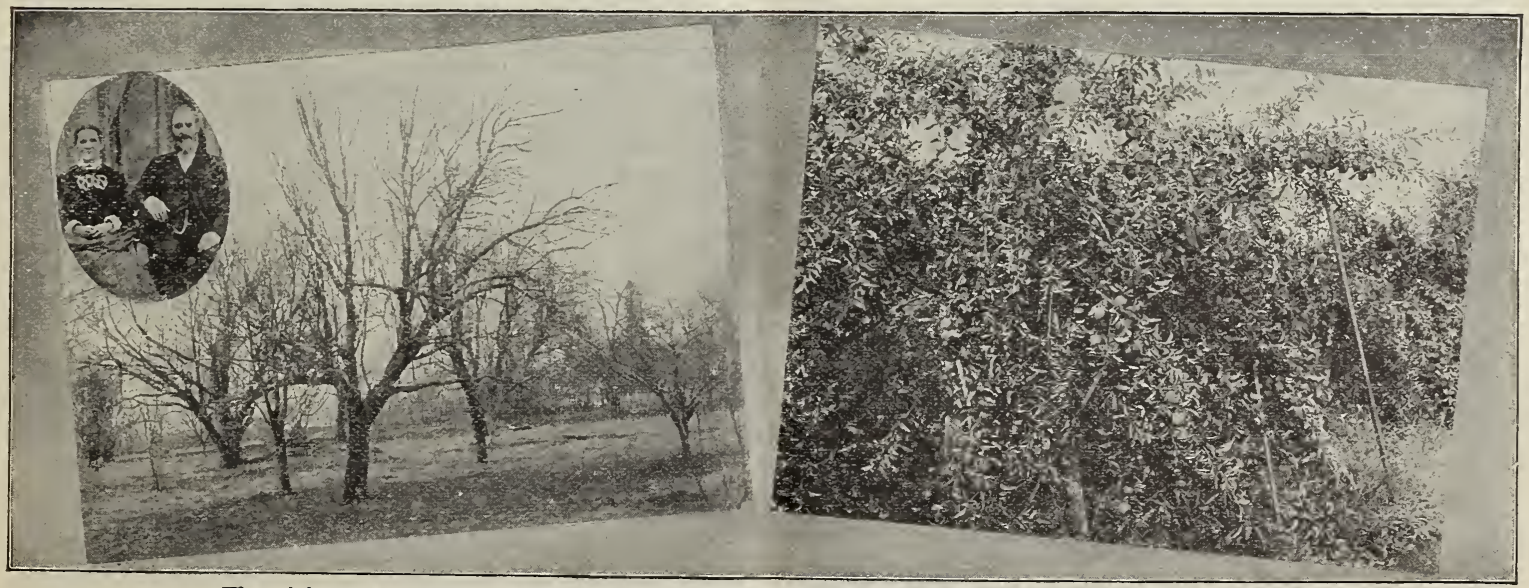

The originator and original tree of Stark Delicious

One of 100 Stark Delicious trees in the Bailey orchard, Chelan County Washington, that in 1908 earned $\$ 2,000$ 
tails pleased me very much, coming trom such a source-no one stand er in Chicago on high-class eatables.-J. S. HסEx, Chicago.

Illinors. Our Delicious have just commenced bearing; the finest apples we ever ate and everyone else says the same. Keeps well, no

Illinors. Delicious and King David were fine and seemed to come up to all you have said. King David is a fine cooker, and one among the best flavored dessert apples I have ever seen; has that agreeable acid flavor that is in the old Winesap when at its best, and the texture of the flesh is all anyone could ask. Delicious, as a dessert apple alone, is in a class by itself nothing equals it in my opinion. King David, on my young trees have never had a chance, and, by the way, the Delicious I grow don't have those five prominent protuberances, but you can't beat me on quality. I am more than pleased with both varieties.-G. W. ENDicotT, Pulaski County. Fair, and Delicious apples grown by that veteran fruit-grower, Mr. Harrington, of Iowa, took first prize for quality over all competitors. In Iowa, it is ton, of lowa, took first prize for quality over all competitors. In lowa, it is admiration than any apple ever produced. Delicious has come to stay. Have seen the variety in many states and know it as a strong grower, very productive, a good keeper, and sells higher on the market than any variety yet known. I have engaged all the apples on two trees here for next fall at $\$ 3.00$ per box, when other good v

Iowa. Delicious came through the awful freeze and storm of April 22 and 23, 1910, with scarcely any injury while all other apple trees, twenty eight varieties, were badly damaged in leaf and buds all destroyed. I tell you the Delicious trees look grand in their uninjured foliage while the others

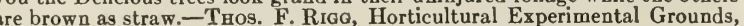
lowa Falls, Iowa.

Iow A. I think very highly of Delicious; the trees are entirely hardy here, thing in any tree.-A. S. BEARY, Hardin County.

IowA. I have ten Delicious trees fruiting in my orchard. When these were planted, I put out thirty-five trees of other varieties; these ten Delicious trees have borne more than all the other thirty-five.-GEORGE Hocketr, Ringgold County.

Kansas. The aroma of the Delicious apple is as delightful as the taste and fills the house with its per

Kansas. I am sending you a specimen apple and would like to know what variety it is. Have only one tree, bought from you nine years ago; everyone who sees the apple is very much taken with it. The specimen is about average size, although some of the apples are much larger.-A. B. EAsterdar, Atchison County.

NoTE. - The specimen sent by Mr. Easterday was Delicious; a very firm, dark, rich, gloriously colored Delicious, of just the right size and as

KENTUCKY. I have some fine apples of your new fruits, such as Delicious, Champion, Apple of Commerce. Delicious is very large, have

Med one that weighed 13 ounces.-W. H. Pierce, Ohio County.
Marne. Delicious is hardy here.-Charles G. AtKins, Hancock inty.

Marne. Delicious trees are thrifty, have stood the cold winters well, and are hardy here-C. Ivory Morse, Cumberland County.

Maryland. Delicious is äne-I can't say enough for it.-Alfred irlison, Allegany County

Massachusetrs. Delicious are bringing 15 cents each in Fall River. REv. J. Williams, Bristol County.

MASSACHUSETTS. I hasten to thank you for samples of the King but Delicious suits me better. It is certainly a fine apple, apples in their window about the size of a small pumpkin and they are all apple to the core. They ask 20 cents apiece for them. I am glad I took your advice and planted my orchard mostly to Delicious.-A. D. Birch ARD, rolk County.

The MAssachUsetrs. I sent by mail a Senator and a Delicious apple extra large.- WM. F. THAYER, Hampden County. (The Delicious was a Massachusetts growers learn the value of Delicious, they will drive Baldwin, , from the Boston market.-STARK Bro's.)

Michigan. Looking over our best varieties planted on North Manitou Island, we find the twelve Delicious you sent us excelling them all. The
apple has good size, rich color, and remarkable flavor. They ran about apple has good size, rich color, and remarkable flavor. They ran about cellar, a few apples and the quality and flavor was still there. You need HALL \& SoN, Chicago.

Michigan. I have a small orchard of Delicious which has borne three crops. Trees are now eight years old, they fruited the fifth year and they grow to perfection here. I consider them the finest apple ever grown in this country; trees are healthy and hardy. Northern Spy planted by the side
of Delicious froze, but Delicious gave a good crop.-JoHN VERSNYDE, Leelanau County.

Michigan. Have Delicious trees in bearing-quality of the fruit not be excelled.-JosePH A. ButLer, Emmett County.

Michigan. I was in Chicago several days last week and visited some of the high-class fruit stores where I found the Delicious in great abundance. Kunze on Randolph Street had their window full of Delicious, King David, and several other varieties. Delicious apples were selling at 20 cents per
apple. I think they were the largest and most beautiful apples I have ever apple. I think they were the largest and most beautiful apples I have ever
seen. The fruit-stands out on the street were selling Delicious of a smaller size at 10 and 15 cents each. From what I saw there I was convinced that the apple business is better than growing oranges.-F. E. BEATry, Pre

Mrchigan. Last season I picked 13 bushels from one ten-year-old Delicious tree. Having no cellar, we buried them in the ground; commenced using them the first of February. No man ever tasted a better apple.(Mrs.) Serena Lewis, Sanilac County

Mrnnesota. Delicious has made a good growth.-C. M. Jenson,

Minnesota. Delicious seems to be hardy here. I planted just a few trees that I got as premiums from your nursery, was afraid to purchase trees to plant, so bought scions and top-grafted. Up to date, I do not see
but what the whole tree is just as good as the top-grafted ones, and apparently as hardy as what is generally designated as hardy northern kinds, as
Wealthy and Patton's Greening. Last winter, 1908 and 1909, we had three weeks that the thermometer dild not go above zero, with it down from 15 to $\mathbf{3 5}$ degrees below every night. I expected to have a lot of brush to burn in the shape of Delicious trees, but they came out with just the terminal

LATER: July 19,1910-We had 16 degrees of frost and a fifty-mile wind. I feared at the time that every tree in my orchard would be killed outright; we have oaks and box elders stone dead from the effects of that day's cold, but the apple trees have recovered far heyond what I cxpected. elicious has recovered as good as any of our so-called hardy northern kinds.

Missouri. I regard the Stark Delicious as far and away the best apple I ever tasted, and I consider myself something of a connoisseur. It is a part or my daily life to eat one or more apples, and I nearly always eat them raw. I am a nervous dyspeptic, and find that a raw apple after meals quick my digestion very much indeed. Therefore, I am especially keen and apples. I would rather have Stark Delicious than any other apple I have ever eaten, and I believe this would be the verdict of almost cvery lover of apples, who is fortunate enough to have an opportunity of testing the question by enjoying one of your Stark Delicious-E. C Srurov, Pres. Simmons Hardware Co. (Keen Kutter Tools), St. Louis, Io.

Missouri. I want to tell you that the box of Stark Delicious apples you sent me are the finest I have ever eaten and, in my opinion, are unexdelightful.-B. F. EDwards, Pres. National Bank of Commerce, St. Louis, Mo.

Mrssouri. I find the Delicious tree a strong, healthy and vigorous growing tree, especially strong and healthy, as my trees were set out and practically left to care for themselves in sod and underbrush. We did not fully understand their value up to the last few years when they began to bear-this year an especially good crop when frost practically ruined al other varieties. Delicious are certainly frost-proof. I am especially glad I
have started another orchard of these trees.-C. M. FETTE, Vice-Pres. Mishave started another orchard of these trees.-C. M. FETT

Missouri. Your Delicious apples seem to be growing in favor around Koshkonong. An orchard here, which I have spoken to you about before has a good crop this year; they have not been sprayed, but are well loaded was a good crop this year; they have not been sprayed, but are weil that had with fruit of good size. I saw these trees last week and am convinced that had
they been sprayed they would have produced some Delicious apples as fine as any I have seen on exhibition.-R. M. Hrtw, Oregon County.

Montana. Our experience with a young orchard is that Deliciou excels all in hardiness. Where cottonwood trees will grow, Delicious will grow. The apple is without a peer. Black Ben, McIntosh, N. W. Greening, Carbon County.

Montana. I consider Delicious the best all-round commercial apple in my orchard of over forty varieties; the tree very hardy and a strong and vigorous grower; apple good size, color and flavor unsurpassed, and a better keeper than Ben Davis. Begins to bear at three years from planting. Two of June, I exhibited Delicious, kept in an ordinary cellar, as sound as when they were picked from the tree.-R. A. Rollins, Flathead County.

Montana. Delicious is a good grower, very symmetrical, and capable of carrying a heavy load without injury to the tree. Only wish I had more Delicious in my orchard.-F. B. Elmer, Jefferson County.

Montana. The Delicious is the best of all in quality and a good keeper.

Montana. Delicious and Black Ben stood the past winter; buds of everal other varieties killed back. Delicious better than McIntosh.W. J. SAwYER, Yellowstone County.

New Jersey. Have Delicious apples in my cellar now (February 11) as nice as when they were picked. It is a splendid keeper. They are just like the sample you sent me, exce
P. L. BELsorl, Atlantic County.

New Mexico. I learned that one man at Roswell (New Mexico) received $\$ 18,000$ for the fruit of twenty acres of Stark Delicious. - R. C Bristol, Hillsdale County, Michigan.

NEW MExico. I have twenty-five acres of bearing orchards, all Stark trees. About three hundred of these are Delicious. These trees up to the last year when I purchased the ranch were utterly neglected. Last year got twenty-six boxes of Delicious and this year sold three hundred boxes at $\$ 2.15$ per box f. o. b. Roswell, the highest wholesale price ever received for as large a quantity of apples in this country. They were shipped all over the United States to customers of the Gross, Miller Grocer Co. Prof. Powell told me that these apples were the most beautiful he had

New Mexico. We handled all of P. D. Southworth's Stark Delicious which as about three hundred boxes. We marketed them here in Roswell and sold at $\$ 3.00$ per box. Some of these apples we shipped to Illinois, Michigan, Pennsylvania, and New York, and the recipients would answer"a very appropriate name," "the most delicious apple we ever ate," etc. We have good success with them and only regret that we could not get more Grocer Co., Roswell, New Mexico.

New Mexico. I have seen a good many boxes of the Southworth crop of Delicious. They are very fine-equal to the best specinens sent me by Frank Femmons of the mountain apple region of California. They are uniformly large, of fine form, with less of the characteristic and identifying protuberances about the calyx than those that came from the far Northwest. are a finer lot of Delicious than have ever come here from elsewhere. They are a credit to the country that produced them, and to the man who handled the machinery. Nearly three hundred boxes of them have been retailed here by one dealer at prices from $\$ 2.50$ to $\$ 3.00$ per box in this town, which is so full of apples-and good ones too-which are selling at around $\$ 1.00$ per box. It is a

New York. What a "delicious" way you have of sending out your superb catalogue, imbedded among the fruits of rare perfection. I havc just one criticism-that you Jid not make all the fruits Delicious. That apple is certainly a wonder, and if my feelings toward it are any criterion. I think it is going to sweep all otlirr varieties before it.-L. B. JUDSON,

New York. Delicious t. uited for the first time on our grounds this past season. We are yery muc, pleased with it, especially as to quality.tion, in a letter to J. L. Ince, Portiand, N. Y.

New York. Up to the presini time the King David apples we have received have been sold. We canno.. ive you the refusal of the entire lot as there is a large demand for those two varieties on this market, especially the 
Delicious; what few we have this season we have already promised most of them to our high-class trade which we have held for the last ten or fifteen years.-E. L. Loom1s, Commission Merchants, New York.

New YORK. Delicious needs no commendation from any one-in uality it is unurpased D. D. Wutro Ontario County.

NEw YORK. I do not want any better apple than Delicious, it is the best eating apple I have ever tasted. Have not had any to sell this

but have given some away for trial.-Thuman TeMple, Washington Coun New ZEALAxD. Delicious is coming more into demand here than is absolutely free from whooly aphis-D. HAY \& SoN, Auckland. Norta C.Arolis. Samples of Delicious, Black Ben, Stayman, and King David arrived in good shape; they certainly were fine, but the joke is on you as I have finer Delicious, Stayman and Black Ben in my cellar, grown on my owu Stark trees here in North Carolina than the samples sent. I bought my trees of you nine years ago. My Stayman, Rome Beau ty, and Ingram bring trees of you nine years ago. My Stayman, Rome Beaucan't begin to supply the denand.-J. C. Bushnelu, Polk County.

Оног. I have the samples of Delicious apples-they are certainly fine pecimens of the variety. We have quite a collection of apple varieties on hand, and among the rest were some Delicious grown at the Experiment Station at Wooster. These were not so large as the ones you sent and are quite differently formed; however, the variety grown here makes a very good showing.- Prof.

Онго Delicious is in full bearing this year-all it will hold without breaking down. The fruit is finely distributed throughout the tree so as to bear full without thinning. They hang on well during drouth. The tree looks fresher than any other during this summer's dry spell.-JoHN CoTtue, Washington County.

Onio. The name "Delicious" that tells the story. Some of my trees bore one-half bushel this year.- W. F. Strayer, Luca County.

OкLaнoma. Delicious from Lincoln County took the first premium at the state fair at Oklahoma City this week.-S. L. Hosterter, Canadian County.

OKLAнома. Having purchased one hundred Delicious apple grafts in the spring of 1908 , I will make a short report of their growth. The first year planted them; although the season was very dry I lost none of them. Thi past year they made a fine growth and also branched out very nicely. past year they made a fine growth and also branched out very nicely. I County.

OkLahoma. Delicious trees bought of you four year
gear.-Mat Brown, Grower of fine fruits, Major County.

OrEGon. Delicious are O. K. Would plant heavily.-H. F. J. SiEVERKSOPP, Wasco County.

Pennsylyania. I have Delicious in bearing; they are the best apples I ever ate. Tree is a fine grower and a good bearer. My family won't eat anything but Delicious as long as they can get them. No one

Pennsylvania. I am sending you a sample of Delicious so you can see and taste the Delicious as grown in Pennsylvania. It is larger and fine color than the Delicious I bought last winter at the fruit stands and my family is satisfied that it surpasses them in flavor. It is the best de

Pennory I have ten Delicious trees, eight years planted,

bore nicely last season. The quality was fine, much better than the Pacifi Coast Delicious. I kept them in an ordinary cellar without any care until May 1st - H. H. LAUB, JR., Mifflin County.

Pennsylvania. Delicious is an apple than can't be beat. It does well here. They are fin
Somerset County.

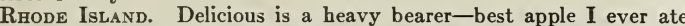
Those that have sampled it say the same. Delicious is the apple for Rhode Island. Delicious I fruited this season were better quality and finer colored than the samples you sent me. Splendid keepers-superior to all apples grown here in quality.-Roвert B. Almy, Newport County.

Soбтн DАкотA. I have six hundred Delicious trees set last year. They are the healthiest and best looking young trees I ever saw; went through the winter in fine shape. I measured the new growth made by one
of them this season and it was exactly 43 inches.-H. LEPPA, Lawrence of them

South Dakota. Have fruited Delicious four years on our South Dakota farm. STOOd 40 degrees Below zero AND FRUITED WHEN JoNA-

THAN FAILED.-D. M. Dickerson, Woodbury County, Iowa.

TENNEssee. Tree is healthy, vigorous, and productive, while the fruit is sprightly and most excellent-one of the best.-H. L. FAIRCHILd, Fairld County.

Tennessee. I have examined Delicious both in Virginia and at the Tennessee State Fair and find that it has succeed
these states.-G. B. Bracket, U. S. Pomologist.

Tennessee. Delicious stood the frost best of all the past season. Large red, conical, good bearer, thrifty grower and hardy.-LANDON AYREs, Greene County.

Texas. I have sold sixty Delicious trees four- and five-year. They are thrifty and do fine in Texas. My orchard of Stark trees is said to be the finest in Denton County, by all who have seen it. I have about six hundred

Utaн. There are no old trees in this section, but a tree planted two years ago last spring bore three fine specimens this year. As a tree there is none better in the valley.-EDGAR ADAMs, Emery County.

UтAн. Stark Delicious is entitled to special praise, as it meets all the requirements of a winter apple as to size, shape, color, beauty and keeping
qualities. Tree is very hardy and when planted here extensively will become qualities. Tree is very hardy and when planted here extensively will become as popular as Jonathan and that is saying a good deal

Virginia. M. B. Miller \& Bro's, Bridgewater, Va., placed some very fine Delicious apples on exhibition at the recent county apple-show held at Harrisonburg, Va. You happened to have on display, apples of this variety grown in Washington. The Virginia-grown Delicious outclassed them in color and quality, but did not quite equal them in waxy finish. All things considered I believe the Virginia Delicious was superior to your Washing ton samples.-H. L. Price, Montgomery County.

Virginia. I have examined Delicious both in Virginia and at the Tennesser State Fair and find that it has succeeded admirably thus far in these states.-G. B. Bracketr, U. S. Pomologist.

Virginia. I was at the Virginia State Fair this week and on going through the Horticultural building was surprised to see what a splendid howing Stark Delicious apple made.-FurmaN AGeE, Albemarle County.
Virania. This is the first year that Virginia orchardists will pack Stark Bro's Delicious, and we want you to know it is making friends amon all fruit-growers and is sure to growin favor as the young trees planted come into bearing.-MAGIE Bro's, Augusta County.

VIRGinia. Our Delicious trees have the finest, handsomest, best apples, I think, we ever saw or tasted. One tree has 110 apples for its first crop. Virginia. Have some Delicious trees describes the unsurpassed flavor of the fruit and I believe the trees will prove regular and heavy bearers in this section.-W. W. BIRD, Russell

(NOTE.-Stark Delicious is fruiting in every fruit section of Washington. and fruit, and as a money-maker outranks any apple ever grown in this and fruit, and fac is almost unlimited, so much so that we could devote a whole section of this book to them, but since the variety is so well known, we are simply reproducing a few of the representative letters from the different sections of the state-STARK BRo's.)

WAshington. I think highly of the Delicious and also of the King David apple. In fact, I am going to plant these varieties and am sure any orchardist who plants them will not make

Washington. I cannot say too much for the Delicious. They are here to stay, any one having ground enough to stand one tree should fill that pace with a good healthy Delicious.-F. DANDO, Chelan County.

Washington. Delicious appears to be the favorite apple in this vicinity. In the yearly sale of apples seventy-five cars were sold at a uction by th Wenatchee Valley Fruit Growers' Association and the following prices were
obtained: Winesap, $\$ 2.25$; Spitzenburg, $\$ 2.50$; and Dclicious, $\$ 3.00 .-\mathrm{R}$ G. McDodgal, Chelan County.

Washington. Delicious sold for $\$ 3.00$ per box f. o. b. shipping staWash.

Washington. I have thirty-six Delicious trees, nine years old. They began bearing the third year and have borne every year since, the largest
crop being that of this year, 1910, averaging fifteen boxes to the tree. The crop being that of this year, 1910 , averaging fifteen boxes to the tree. The gross returns will be not less than $\$ 1,500$. I have already sold 250 boxe
for $\$ 3.25$ per box and the balance will bring from $\$ 2.00$ to $\$ 2.50$ per box. The tree is hardy and is less bothered by codling moths than any other in my orchard. If ever I plant another orchar

Washington. In apple and tree Delicious is without a peer. Tree is a beautiful upright grower, in vigor even surpassing Black Ben. Fruit is well distributed over the tree, and they have the faculty, when overloaded, of thinning themselves. The tough fiber of the wood and the formation of the tree enable it to carry an immense load. Owing to the vigor of the tree, the texture and thickness of the leaves, it is comparatively free from the ravages of aphis and other plant life. The apple is attractive in appearance and takes on a beautiful color; in quality it belongs to the superlative three years sold on the general market at higher prices than any other for It is being extensively planted and deserves to be in every orchard. It is a great apple and has a great future as a standard commercial sort.- 0 . M Wors, Chelan County.

WASHIngton. Last spring I planted Stark King David and Delicious with Rome Beauty and Jonathan from other nurseries, and their performance is so much superior to the other varieties that I will plant nothing b elicious and King David this year.-A. H. HEw ITT, Spokane County.

Washington. Among our new apple trees we cannot praise your
Delicious too highly. It does fine in our section.-JoHN J. RANAHAN, Stevens County.

WAshington. I have the finest crop of Delicious that a Missourian ever saw. I have four hundred trees and they are loaded, limbs touch th ground, but never break. People come from far and near to see my orchard. DICK HART, Yakima County.

Washington. The writer has examined the Stark Delicious quite carefully in one large orchard and finds the trees to be vigorous, stron growers. The Delicious apple from the standpoint of quality and flavor hard to excel. Its flavor is peculiarly aromatic, pleasantly sub-acid, almost sweet and particularly enjoyed by many who do not enjoy the acid tart varieties, such as the Spitzenburg. With such the Delicious apple will stand at the head of the list.-H. M. Gilbert, Richey \& Gilbert Co., Yakim County.

Washington. I will have some sixty boxes extra-fine, large Stark Delicious apples. They are prize-winners from trees purchased from you some years ago.-U. G. MerriLl, Yakima County.

WASHINGTON. I am sending by express samples of an apple I have no name for. Kindly compare with your Champion or Magnet-or make an attempt to name same.-F. H. HoNTER, Yakima Valley.

(Note.-Mr. Hunter's apple proved to be Delicious; the highest color, Valley.-STARK Bro's.)

\section{Washington. F.}

Washington, From thirty-six Deicious trees he had 648 boxes, an average of eighteen boxes to a tree. Three hundred and fifty boxes were sold to the Stark Bro' Nursery at $\$ 3.25$ per box, and for three hundred other boxes he received seventy Spitzenburg trees he picked 2,700 boxes, of which 2,200 are extrafancy and fancy, selling them at $\$ 2.25$ per box. Other varieties are Stayman Winesap, old Winesap, and Black Ben Davis. The total yield was 8,000 boxes. The crop returns this season were $\$ 2,000$ per acre-FruI Trade Journal and Produce Record. November 19,1910

Washington. Louis W. Hill, President of the Great Northern Railway Co., sent the following telegram from St. Paul yesterday to $R$. H. Rice Secretary and Manager of the Third National Apple-Show: "While in Chicago last week I called at a fruit store near the La Salle Theater, which had a large display of Wenatchee Delicious apples. The large size sold at 25 cents each. The storekeeper showed me his sales-book that he was selling them at $\$ 8.50$ per box."-Spokesman-Review, Spokane, Wash., Octobe $19,1910$.

Washington. C. W. Babcock, Cashmere, Wash., from one Delicious packed thirty-one boxes of apples, twenty-five extra-fancy and six fancy. which sold for \$99.25.-Twice-A-WeEk SPokesman-REview, Novembe $11,1910$.

WEST VironniA. I am in receipt of specimens of Delicious grown by
C. S. Scott, Sinks Grove, W. Va., which I am glad to have as it shows very 
plainly that Delicious is doing well in that section of the conntry.-Hon. G. B. Brackett, U. S. Pomologist.

IVest Virginia. Delicious bears as heavy as Ben Davis in West Virginia, as I found a farmer with six trees of Delicious heavily loaded, also Stayman Winesap.-Raye Kepharte, Mineral County.

West Virginia. Everyone here who has Delicious has a good word for it. Have never heard a single word against it. It is all right in both tree and fruit. Mr. S. W. Moore of Elwell, says it is the best kind he has in his in his orchard. He is one of the best authorities in this state and one with the widest knowledge.

WEST Virginia. If you would only substitute Delicious and Stay man Winesap for the numerous progeny of Ben Davis in dealing with you New England customers you would confer a lasting favor on lovers of good apples.-W. M. Munson, Monongalia County.

Wisconsin. Delicious colors well here and the tree is as hardy as Black Ben or Senator.-Wr. CEzAR, Jefferson County.

Wyomisg. Your colored reproduction of Stark Delicious is very fine, but if you could have had the Delicious apple now on my desk at the time your cuts were made you would have a prettier picture, more richly colored. Ir. Mr. Jordon sent me a dozen Stark Delicious that have set this community on fire. It is not Decessary for us to experiment with other varieties, be cause these apples grew seventeen miles rom my office. They are superio to any apple I have ever seen, both in color and flavor, just the right size fo marketing. The sample I prize most highly weighs 6 ounces. "This valley six years from now; will be known all over the United States as "The Valley where the Big Horn Apples Grow."-J. L. Lew 1s, Big Horn County.

Wyomsg. I have traveled all over the fruit sections of the United States and consider that the Big Horn Basin will be a great fruit country. I visited that section last month and was much surprised to find genuine Delicious apples of high color as firm as an apple sould be, and of medium size, that were size, that were grown near Worland. The apples had been in a cellar a winter and there was no sign of decay. The man who grew these apples had six trees that were sent to him by mistake, but will be worth thousand of dollars to the people of the Big Horn Basin. The Delicious apple sells on the eastern market at $\$ 4.00$ to $\$ 5.00$ per box and is beyond doubt the
best flavored apple in existence to-day.-C. M. Holtzinger, Fruit-Buyer.

\section{Black Ben * \\ (Trade-Mark)}

In every case where an apple of the Ben Davis family is wanted this variety should be planted. In every way it is superior to Ben Davis, Gano, Etris, Red Ben Davis or any kindred apple. The tree growth is of the Ben Davis character, but is even stronger, hardier, thriftier, is a better resister of drouth, its foliage is more vigorous, and it succeeds over a larger territory. Its fruit is one of the very handsomest of all apples, is large, solid deep, dark red (no stripes), and while no claim is made for its being in the high quality class of Delicious, King David, Senator, and others, it is way ahead of Ben Davis in this respect. Its wonderful beauty, however, makes it a profit-earner and a big one. It constantly is quoted at higher prices than Arkansas Black, Baldwin, etc., and often brings the same price at which Jonathan sells-a variety it is often sold as. In the spring of 1909 it sold on Chicago and New York markets at $\$ 3.00$ per box, while Jonathan brought but $\$ 2.00$. In the fall of 1909 Black Ben sold at the Wenatchee (Washington) Fruit Growers' Union sale, at $\$ 2.00$ per box. Jonathan in the same sale brought $\$ 1.90$, Ben Davis $\$ 1.40$, Missouri Pippin $\$ 1.50$, Gano $\$ 1.50$, York Imperial $\$ 1.15$ Rome Beauty $\$ 1.75$, etc. For fancy fruit-stand trade it is a prime favorite and a ready seller. The American people buy color in apples and Black Ben will command first attention anywhere. It is a splendid A-1 keepcr, either in a common cellar or cold storage, does not scald, and bruises, instead of rotting, dry up. No apple will stand hard handling or long-distance shipping better than Black Ben. Why plant Ben Davis, Gano, Missouri Pippin, or other kindred apples when Black Ben succeeds equally as well or better from coast to coast and will outsell them almost two to one? A better apple, in its class, than Black Ben never grew; we urge orchardists everywhere to plant it largely. The following letters will tell you what planters in all parts of the country think of it. NCS

NoтE.- There are nurserymen and dealers cataloguing and selling Gano and Red Ben Davis and representing them, ignorantly or intentionally, as being identical to Black Ben. Such is not the case. Black Ben is a distinct variety and the very best of the Ben Davis family, a variety of general adaptability and which is being planted commercially in all parts of the country by our best and thinking orchardists.

Prices, same as Liveland Raspberry. See page 1.

Have just refused an offer of $\$ 2.25$ per box from a New York dealer for a car load of Black Ben. LATER: Sold Black Ben in New York markets the other day for $\$ 3.00$ per box; Jonathan brought only $\$ 2.00$. Just had a call from Mr. M. O. Tibbetts, President of the Wenatchee Apple Growers' Association. He said: "I have a block of Black Ben which commenced to bear at three years of age and has borne every year. This year, they are eight years old and averaged ten boxes to the tree-they bear heavier than Red Ben Davis."-C. W. Wilmeroth, former Treasurer, H. Woods Commission Co., Chicago.

(NoтE: On the Wenatchee, Washington, markets, season of 1909, Black Ben brought 25 cents per box more than Gano and 75 cents per box more than Ben Davis. Black Ben and Jonathan brought the same price, but later Black Ben brought more than Jonathan on the castern markets of Chicago and New York.-Stark Bro's)

Arizona. Black Ben purchased of you eight years ago are now in bearing and are everything you claim for them.-EMIL KIELBERG, Pinal County.

ARKaNSAs. Spring of 1909 I took up some one-year-old trees of Black Ben and set them in rough rich ground. This spring (1910) some of them have as many as ten to fifteen apples-trees two years old of course.-E. C. BAKER, Marion County.

British Colombia. Black Ben is a grand success; is a regular bearer of large highly colored apples and is profitable in every respect-far excelling Ben Davis.-Tanner Bro's, Nanaimo County.

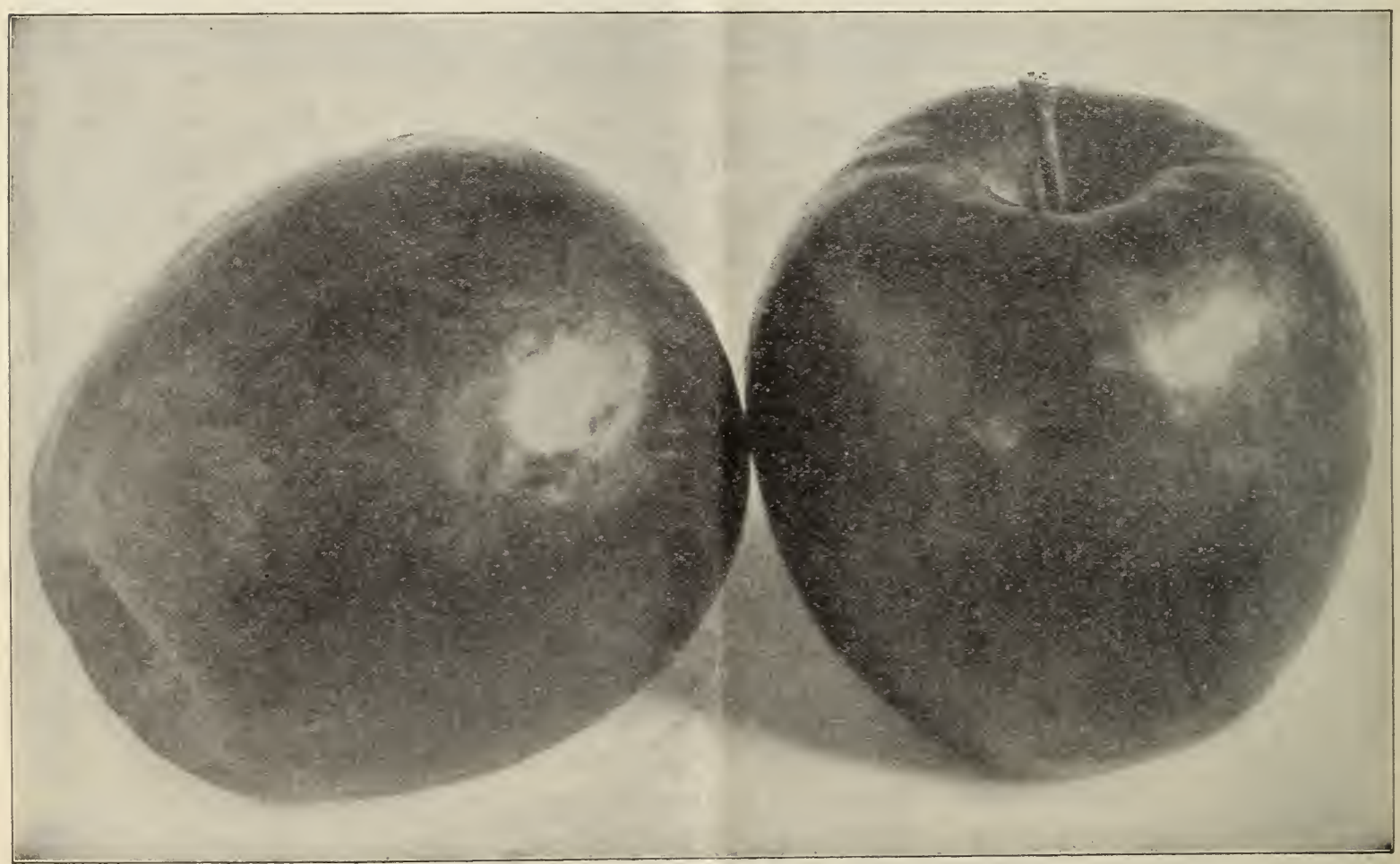

Black Ben - one of the greatest money-makers and the variety that has driven old Ben Davis off the horticultural map 
California. If on November 15, 1910, you could have seen Black Ben trees at Home Orchard still hanging full of the most beautiful apples that have ever been produced, you would be even more enthusiastic over it as a commercial variety.-Frank Femmons, Madera County.

California. Black Ben is by far the most valuable apple for this section, standing as it does the trying climatic conditions that prevail her and bearing every year.-G. E. HeAton, San Luis Obispo County.

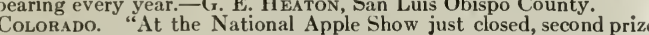
carloads, $\$ 500$, was awarded to car Black Ben apples grown on one hundre and sixty Stark trees at Fruita, Colorado."-Telegram from DR. S. T. and sixty Stark trees at Fruita, Colorado."-Telegram from DR. Green confirmed his telegram by the following letter: The car lot of Blark Ben apples which were awarded the $\$ 500$ prize at the Denver National Apple Exposition in January, were grown on a two-acre Black Ben orchard two miles east of Fruita, Colorado. The one hundred and sixty trees on this two acres are Stark trees eight years old, every one of which is nearly perfect as it is possible for trees to be. Every tree is just like the others, and from them 1,2.50 bushel boxes of the most beautiful apples picked this fall (1909). All of these apples (dark red), and shape. Mr. J. C. Wilson, the owner, received for the apples fom these

Colorado. Black Ben is and will be for a long time to come, the poor man's apple. I mean by this an apple that fills the boxes and barrels like old Ben and Gano but a much better fruit in every way and on account of its bountiful yield, can be cheaper grown than other fancy varieties and therefore is within reach of the masses. Black Ben is even a better keeper than old Ben Davis and stands further shipping and rougher handling better than any other apple we have.-Theodore Polling, Delta County.

GEORGIA. Black Ben for quality and size is ahead of anything $I$ have my orchard -J. C. Johnston, Milton County.

GEORGIA. I have eight hundred Black Ben trees in one body and most of them will bear this year. I had about two hundred trees that bore last ycar, some at two years old, which brought me a good price. I have been growing fruit for thirty years, and trying to find the best apple. I consider Black Ben best of all others. It took the first prize at the County fairs at abun and Habersham.-M. L. Arrendale, Rabun County.

IрАно. Black Ben pays the planter more money and bears every year, rost or no frost, than any other.-A. Y. SATTERField, Bingham County. ano, are larger, color better, and are much better in quality. $-\mathrm{N}$. $\mathrm{C}$ Thompson, Kootenai County.

ILlinors. Black Ben fills the bill for a commercial apple. It will always command a better price than Ben Davis.-J. M. Francis, Adams Co Illinors. Black Ben is way ahead of Ben Davis or Gano. We will never plant another tree of Ben Davis, Gano or Missouri Pippin and have
been replacing the dead trees of these varieties with Black Ben.-EAsTMAN \& Co., Jersey County.

ILLINors. Black Ben is king of the apple family for this climate. Trees grow better than any other varie

IndiaxA. Black Ben is a wonderfully fine colored apple. If it were not any better in quality than old Ben, the color would be worth planting n preference to old Ben.-F. Bieck, Warwick County.

Kansas. In my sixteen-acre apple orchard, one hundred Black Ben trees are the best bearers and bear the best apples.-C. C. MCDowel, Chase County.

MAINE. Black Ben set three years ago, fruited this year; fine color, good size, and appears solid enough to keep forever.-G. Ivory Morse, Cumberland County.

MaIne. Black Ben is as handsome an apple as I have ever seen.R. T. Patten, Somerset County.

Maryland. Black Ben is much like Ben Davis, except it is a little longer and smoother in outline, very dark solid red color, fragrant, and not so poor in quality as Ben Davis, to which variety it is to be preferred.porr in quality as Ben Davis, to

Michigan. Black Ben, in my opinion, is head and shoulders above all apples for commercial purposes that I have yet seen.-E. W. RoBIson, Ontonagon County.

Missouri. Black Ben grew faster, stronger, bore younger, and kept cleaner from insects than any other trees in my orchard. The fruit keeps well and stands more handling tha
WM. S. DAwson, Cole County.

Missouri. Black Ben is hardier, healthier, a better bearer, has better color, better quality and better keeping qualities than Gano or Ben Davis. Mr. F. Atchley of Brice, Missouri, an orchard man, and a Ben Davis one
too, now says if he ever plants any more trees he would prefer Black Ben too, now says if he ever plants any more trees he wo
to any other apple.-W. H. Scotr, Laclede County.

Missouri. Black Ben is a fine commercial sort. In size and beauty of coloring it cannot be surpassed.-M. T. RoBer Tson, Wright County.

Montana. Black Ben is a favorite in Montana; a fine keeper and a good seller. It takes the lead with us.-James R. Stevens, Carbon County.

Montana. Black Ben began bearing two years after planting and has borne annual crops ever since of large handsome apples, far better in flavor than Ben Davis or Gano. No other variety in the orchard will bring as much money or quicker sale. For uniformity in size and general appearkeep here at Rollins into May and June. If I were putting out another orchard I would plant two-thirds of it to Black Ben and Delicious.-R. A. Roluins, Flathead County.

Montana. Black Ben is a vigorous grower and a young bearer here. The very best commercial apple on the market to-day, on account of its beauty, glorious color, and tough skin and may be shipped around the world twice and still be in first-class condition. It is certainly the only apple for the masses.-F. B. Elmer, Jefferson County.

Montana. Here in the Bitter Root Valley, I have been watching Senator and Black Ben for the past five years and have decided that Black Ben will be one of the best late winter apples grown in this section. It should be planted with McIntosh to satisfy the desire of many planters New Mexico. Black Ben for this section is fine; bears heavily of large apples of the most beautiful solid red color.-ARCH MCGREGor, Grant County.

NEw York. Do you know that in New York, there is far more money in raising Black Ben than Baldwin? It would be hard to make York state growers believe it now, but the day is coming when they will know it. For

NEW York. I regard Black Ben as a variety of such beauty and quality as to be deserving of attention and should be universally grown. - S. D. Willard, Ontario County.
New Yosx. Black Ben bore a large crop at seven years from planting-the handsomest sight I ever saw, large red apples all over the trees. It is my opinion that Black Ben will mak

NEIV YORK. Superb in color, size and keeping qualities; flavor totally unlike Ben Davis. A great commercial variety.-ORCHARD AND Fruit Garden.

OrEGON. While it has the characteristic odor and tough oily skin of the Ben Davis family Black Ben is juicier and has far better texture and flavor than old Ben Davis, making it a good general purpose apple.ordon P. Miller, Unatilla County.

OrEGon. Black Ben is a grand apple in every way and surpasses al others in beautiful color-not excepting any variety and is something cxtr for culinary purposes. I was surprised to find it had such fine flavor, whil no apple can beat it as a shipper. You have done the apple growers of the country a great benefit in discarding Gano, Ben Davis and Mlissouri Pippin and in urging them to plant Black Ben, etc.-(Mrs.) Lorenzo Stilwell, Union County.

Pennsylvanis. I have had two crops from Black Ben trees planted six years ago. They are fine apples of large size, and I think every person in this county should plant more Black Ben.-WM. H. M ELLotT, Fulton County.

Pennsylvania. I consider Black Ben one of the money-makers owing to its color, good keeping and shipping qualities, and would discard all other of the Ben Davis family. Gano I consider among the poorest that grows. If I were to plant another orchard to-day, I would set nothing but Black Ben, Jonathan, Delicious, Rome Beauty, Stayman Winesap, and Banana. Had I taken your advice when I planted my orchard, I would not have many worthless kinds.-D. H. WY ANT, Indiana County.

Pennsylvania. Black Ben is very large, better than Ben Davis, and I believe, as Mr. E. P. Powell says, that an orchard of them is as good as a gold mine- - HenRY A. Roenner, Northampton County.

RHODE IsLAND. For size, beauty, color and heavy bearing, Black Ben cannot be beat. Quality is good, far superior to any of the Ben Davi family. Sold them on our Newport market for $\$ 1.50$ per barrel more than Baldwin.-Robert B. Almy, Newport Count

UTAн. Black Ben is a fine apple for western growers to plant for shipping. Its color is far better than Gano. EDwIN PARKER, Weber County.

Davis.-A. A. HALLIDAY, Windham County.

WASHINGton. Stark Black Ben in our experimental orchards is on of the most promising apples we

Washington. Black Ben is taking the place of Gano and old Ben Davis; it is the apple for long shipment and is mighty good eating early in

WASHIngton. Planted Black Ben yearlings seven years ago this spring. Last year they averaged eight boxes to the tree.-R. P. Wright helan County.

Washington. Black Ben's splendid color, long keeping quality and extreme productiveness make it one of the most profitable sorts grown year's rest, but Black Ben is always there with the goods. It is also a success here with little or no irrigation. Outclasses Gano and Ben Davis in every respect.-O. M. Brooks, Chelan County.

W respect.-O. M. Brooks, Chelan County.
WAstron. Mr. O. G. Franer of Wenatchee says that Black Ben shipped from here as "Aristo Black" is the greatest money-maker we have
in the valley next to Winesap.-T. H. A Arkinson, Chelan County.

\section{Van Deman Quince *}

Originated by Luther Burbank-a strong grower, the hardiest, surest, and youngest bearer we know and succeeds farther north than any other variety. Will produce more large, fine-flavored, golden fruit than any other quince. Delicious for preserves, jellies, or quince syrup. Ripens through a long season and keeps well. It is the best of all and worth all other quinces put together. NCS

Two Year and One Year

\begin{tabular}{|c|c|c|c|c|c|c|c|c|c|c|c|}
\hline \multicolumn{4}{|c|}{ XXX } & \multicolumn{4}{|c|}{$\mathrm{XX}$} & \multicolumn{4}{|c|}{$\mathrm{X}$} \\
\hline Each & 10 & 100 & 1000 & Each & 10 & 100 & 1000 & Each & 10 & 100 & 1000 \\
\hline .75 & 7.00 & 65. & 550 . & .65 & 6.00 & 55. & 450 . & .55 & 5.00 & 45. & 350. \\
\hline
\end{tabular}

California. Van Deman often weigh 25 to 26 ounces. Most superior flavor, texture, quality tender; baked, canned or dried it retains the best quince flavor. Side by side have to Van Deman in size, quality flavor, and beauty. LUTHER Burbank. (Some of Mr. Burbank's creations are of greater value than others, some may lack adaptability; but in Van Deman he gave the world the best quince. We bought the variety some year ago, and it has never disappointed us. In Mr. Burbank's first description of it he said: "Will produce more big, fine flavored, golden fruit than any other; none can compare with it in size, quality, flavor and beauty."-STARK o's.)

Washington. Two trees set out two years ago last spring, bore $t$ wenty fine quinces, weighing from 12 to 14 ounces each. The first crop ripened about four weeks ago, second crop is ripe now and is fully as large as the first. Quinces sold on Spokane market at $t w o$ for 25 cent and I think it has a bright future. -(Mrs.) J. M. MorgaN, Spokane County.

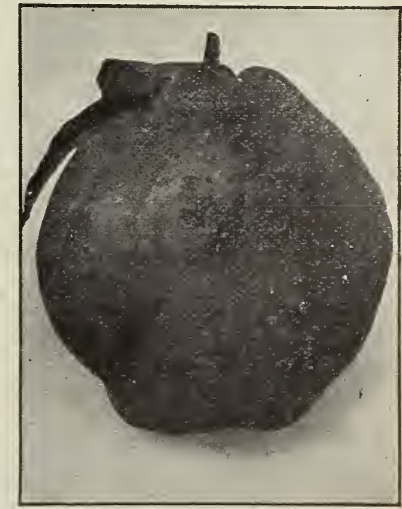

Van Deman quince 


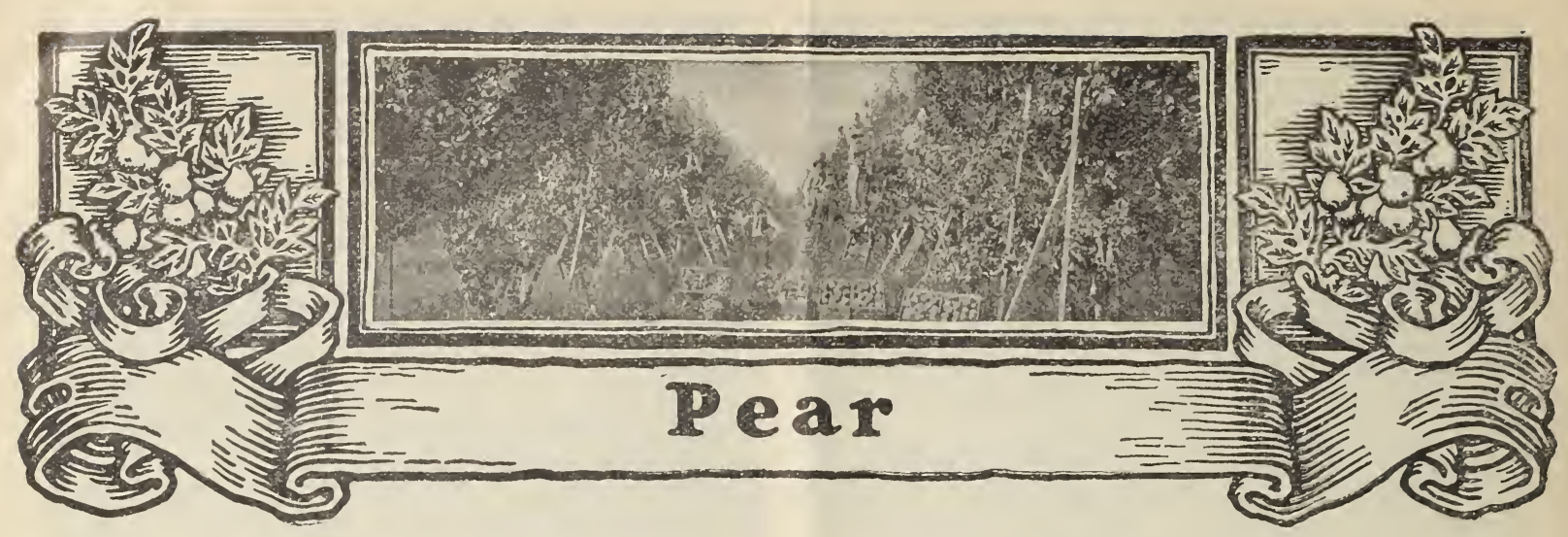

\section{Stark Seckel *}

Riehl's select strain; small, ycllowish-brown, but of finest flavor; tree hardy and blight-rcsistant. This is the finest strain of the Seckel, which has long been the standard of high quality among pears. Planters who know the splendid quality of old Seckel will be pleased with this strain. NNCS

One Year
\begin{tabular}{c|c|c|c||c|c|c|c}
\hline \multicolumn{3}{|c|}{3 to 5 feet } & \multicolumn{4}{|c|}{2 to 3 feet } \\
\hline Each & 10 & 100 & 1000 & Each & 10 & 100 & 1000 \\
\hline 50 & 4.50 & 40 & 330 & .40 & 3.50 & 32. & 250 \\
\hline
\end{tabular}

\begin{tabular}{|c|c|c|c|c|c|c|c|c|c|c|c|}
\hline \multicolumn{12}{|c|}{ Two Year } \\
\hline \multicolumn{4}{|c|}{$\mathrm{XXX}, 5$ to 7 feet } & \multicolumn{4}{|c|}{$\mathrm{XX}, 4$ to 5 feet } & \multicolumn{4}{|c|}{$\mathrm{X}, 3$ to 4 feet } \\
\hline Each & 10 & 100 & 1000 & Each & 10 & 100 & 1000 & Each & 10 & 100 & 1000 \\
\hline .75 & 7.00 & 65. & 500. & 65 & 6.00 & 55. & 450 . & 55 & 5.00 & 45. & 350. \\
\hline
\end{tabular}

\section{Fame *}

(Trade-Mark)

A fine, smooth-grained pear of great excellence, having almost no core and few seeds. Color greenish-yellow, slightly bronzed on sun-exposed side; flavor, very delicious - a more delicious pear we have never eaten. Tree a strong, healthy, thrifty grower, a young bearer and remarkably free from blight. For general planting we consider Fame and Lincoln two of the very best pears. Both are native western seedlings, are hardy and healthy and make long-lived orchard trees. Does exceptionally well as a dwarf. NCS

Prices, same as Stark Seckel on this page.

\section{Comice *}

One of the most valuable shipping and market pears in our entire list, a sure and dependable money-maker for its growers, and a variety that should be much more extensively planted. Commercial orchards of Comice are being planted in great numbers throughout the western orchard regions, where growers have found from experience that it produces far more profit than Bartlett and Kieffer. On Chicago and New York markets it invariably brings top prices -589 boxes of Wenatchee, Washington, Comice sold in New York in 1909 for $\$ 8.00$ per box. Succeeds perfectly in Massachusetts and other eastern states, as well as in the central and far western pear regions. It is one of the very best shippers and a long kecpcr; the quality of the ripened fruit is very fine-luscious and rich with a slight perfume; color ycllow, faintly blushed crimson. Comice is a great pear with a great commercial present and a still greater future-we recommend it with confidence. NCS

One Year
\begin{tabular}{c|c|c|c||c|c|c|c|}
\hline \multicolumn{3}{|c|}{3 to 5 feet } \\
\hline Each & 10 & 100 & 1000 & Each & 10 & 100 & 1000 \\
\hline .75 & 7.00 & 65 & 550 & .65 & 6.00 & 55. & 450. \\
\hline
\end{tabular}

Two Year

\begin{tabular}{|c|c|c|c|c|c|c|c|c|c|c|c|}
\hline \multicolumn{4}{|c|}{$\mathrm{XXX}, 5$ to $7 \mathrm{fect}$} & \multicolumn{4}{|c|}{$\mathrm{XX}, 4$ to 5 feet } & \multicolumn{4}{|c|}{$\mathrm{X}, 3$ to 4 feet } \\
\hline Each & 10 & 100 & 1000 & Each & 10 & 100 & 1000 & Each & 10 & 100 & 1000 \\
\hline 85 & 8.00 & 75 . & 600. & .75 & 7.00 & 65. & 500 & 65 & 6.00 & 55. & 450 . \\
\hline
\end{tabular}

\section{Riehl Best *}

Discovered by E. H. Riehl, of the Illinois Experiment Station, and is probably an old French variety of which the name has been lost. In quality, there is nothing better; fine grained, rich and juicy, free from grit, and entirely exempt from rotting at the corc. Fruit is large, uniform, and smooth; trce large, healthy, vigorous, and free from blight. An annual bearer of immense crops and should be planted everywhere. NCS

Prices, same as Comice on this page.

\section{Kieffer *}

The pear for the millions east of the Rocky Mountains. Large, rich golden-yellow, sometimes tinted red on the sunexposed side; quality fair, though excellent for canning, while baked Kieffer are delicious. To properly ripen for eating Kieffer should remain on the tree until it has reached full size but should then be picked before it colors, which is about the time the leaves begin to fall; then gather carefully and ripen in a cool dark cellar or other place of even tempcrature. The quality is then good. Has become the most profitable market variety on account of its good shipping and keeping qualities; its magnificent size and wonderful beauty make it an ever-ready seller. Tree a most vigorous growcr, an early bearer, one of the most resistant to blight, very prolific, and more widely distributcd throughout the country than any other variety. In planting it is advisable to mix about 10 per ccnt Garber as pollenizers rather than plant in solid blocks, but as we have often stated in our literature, it is best never to plant large blocks of any one variety. NCS

One Year
\begin{tabular}{c|c|c|c||c|c|c|c}
\hline \multicolumn{3}{|c|}{3 to 5 feet } & \multicolumn{4}{|c|}{2 to 3 feet } \\
\hline Each & 10 & 100 & 1000 & Each & 10 & 100 & 1000 \\
\hline .40 & 3.50 & 32. & 250 & .30 & 2.50 & 23 & 180. \\
\hline
\end{tabular}
Two Year

\begin{tabular}{|c|c|c|c|c|c|c|c|c|c|c|c|}
\hline \multicolumn{4}{|c|}{$\mathrm{XXX}, 5$ to $7 \mathrm{fe}$} & \multicolumn{4}{|c|}{$\mathrm{XX}, 4$ to 5 feet } & \multicolumn{4}{|c|}{$\mathrm{X}, 3$ to 4 feet } \\
\hline ach & 10 & 100 & 100 & & 10 & 100 & & & 10 & 100 & \\
\hline 60 & .50 & 50. & 400 & 50 & 4.50 & 40 & 300 & 40 & 3.50 & 32. & \\
\hline
\end{tabular}

\section{King Karl*}

A seedling of Clairgeau, which it resembles, but is more prolific and of bettcr quality; very large, rich yellow, with red cheek; flesh firm, juicy, mclting, and excellent in quality. Fruit hangs well and keeps well. Tree is a strong grower and precocious bearer and almost frec from blight. Grown as a dwarf, we have seen King Karl weighted down with immense pears, the second year from planting. We cannot too strongly advise the planting of this magnificent pear. NCS

Prices, same as Stark Seckel on this page.

$$
\text { Triumph * }
$$

Fruit resembles Duchess, but is supcrior to it in quality and will keep until January. Tree a very young bearer, vigorous and prolific. We consider it one of the best winter pears, and recommend it with confidence. NCS

Prices, same as Stark Seckel on this page. 


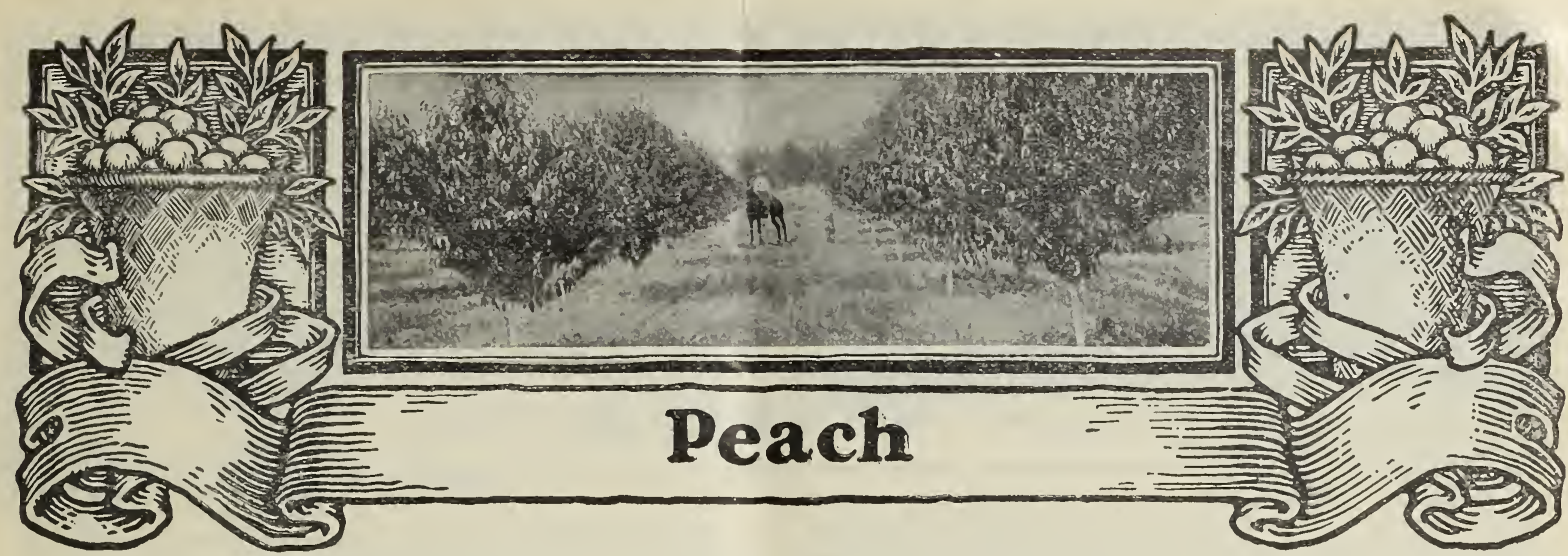

\section{Red Bird Cling *}

Earliness, exceptionally high coloring and good quality make it very valuable. Color creamy-white, overspread with a bright, glowing red; size extra large for an early peach, averaging almost as large as Mamie Ross, and a remarkably good shipper. Tree hardy, healthy, and holds its foliage until very late. Highly ornamental - the blossoms being 2 to $21 / 2$ inches in diameter, and very handsome. Red Bird Cling is the first extra-early good shipping peach, and should be planted largely, while inferior sorts such as Amsden, Alexander and Hale's Early should be discarded. The man who has these fine, handsome, showy, early peaches will have the market hunting him. The advent of the really good early peach opens a new field for peach-growers, and like early apples, not one-half enough are being planted. The man who plants Red Bird Cling will never regret his choice. We cannot too highly recommend it for its season. NNCS

\begin{tabular}{|c|c|c|c|c|c|c|c|c|c|c|c|}
\hline \multicolumn{12}{|c|}{ One Year } \\
\hline \multicolumn{4}{|c|}{$\mathrm{XXX}, 5$ to 7 feet } & \multicolumn{4}{|c|}{$\mathrm{XX} .4$ to 5 feet } & \multicolumn{4}{|c|}{$\mathrm{X}, 2$ to 4 feet } \\
\hline Each & 10 & 100 & 1000 & Each & 10 & 100 & 1000 & Each & 10 & 100 & 1000 \\
\hline .50 & 4.50 & 40. & 3.30 & .40 & 3.50 & 30. & 250. & .35 & 3.00 & 25. & 190. \\
\hline
\end{tabular}

Arizona. Red Rird is the first good peach to ripen with us; they are fine and I believe they will be the commercial peach of this valley for they ripen the first of June and will ship anywhere, while their looks and quality will sell them in any market.- HALL BRo's, Maricopa County.

Arkassas. Shipped Red Bird Clings June 8th, 10th, and 11th, selling them at an average of $\$ 1 \frac{1}{4} .20$ per bushel. LATER, 1909: Finest eariy peach grown; holds its foliage until very late-a great protection. Elberta crop short on account of cold, but Red Bird Cling has an abundant crop.-W. A Jefrers, Crawford County.

Texas. Red Bird Cling is superior to any early peach I have seen, very similar here to Cld Mixon in size, color, shape, flavor, hardiness, and heavy bearing. Has splendid shipping qualities.-E. W. Kırkpatrick, Collin County.

\section{Eureka* $(\mathrm{F})$}

A very delicious, large, beautiful peach of good flavor, surpassing in value all others of its season. Flesh almost as firm as Heath Cling. Superior to Greensboro. In 1909 in this locality, most peaches were a failure, but Eureka produced a good crop of splendid fruit. Incomparably more beautiful, of better quality, a better orchard tree and a better shipper than the old Hale's Early, to which many western growers still cling, not knowing there are better sorts, such as Eureka, Alton, etc. NNCS

Prices, same as Red Bird Cling on this page.

\section{Alton * ( F)}

The best all-purpose peach. A magnificent, large, white peach with handsome red cheek; ripens several days earlier than Carman and is much better quality, is handsomer and more valuable. Flesh white, firm, juicy and melting, with a rich satisfying flavor. In quality it is the very best-in tree and bud one of the hardiest; reports from all over the country show that it bears where all others fail. In the Yakima Valley in 1908, it commanded more than double the price of Elberta, as it comes on the markets at a season when good peaches are scarce. In the vicinity of Alton, Illinois, from which it takes its name, it has given more and larger crops than any other variety. It has made good everywhere and when its value is fully known, it will stand as Stark Delicious does among apples-at the very top. For years we have propagated more Alton than any other variety except Elberta. Plant Alton commercially for large profits. NNCS

One Year

\begin{tabular}{|c|c|c|c|c|c|c|c|c|c|c|c|}
\hline \multicolumn{4}{|c|}{$\mathrm{X}, 5$ to 7 feet } & \multicolumn{4}{|c|}{$\mathrm{XX}, 4$ to 5 feet } & \multicolumn{4}{|c|}{$\mathrm{X}, 2$ to 4 feet } \\
\hline & 10 & 100 & 10 & & 10 & 100 & & & 10 & 100 & 10 \\
\hline 50 & .50 & 40 & 350 & 40 & 3.50 & 32. & 250 & 30 & 2.70 & 22 & \\
\hline
\end{tabular}

Arkansas. Have fruited Alton for five years and not a failure. Quality very best; large size, hardy in bud.- H. D. Mortos. Pope County.

Arizona. Alton is the finest eating peach we grow and a very heavy bearer of strictly fancy, peaches. - HALL BRo's, Maricopa County.

IDAHO. Carman is a nice peach that ripens early; Alton and Woolsey are fine peaches, a little later than the Mamie Ross. The four varieties mentioned all grow large. My Elbertas have not come into bearing to any extent. I think they will produce well, but they do not have the flavor of the other varieties.-A. J. GreEN, Twin Falls County.

InLiNors. Sold Alton this summer by the wagon-load at $\$ 1.50$ per bushel and people simply fought for them. LATER: An glad to know Alton has so well justified my estimate of it. Think I can claim to have rescued it rom oblivion, and I think I did a good deed when I did so.

ILLINors. Last year Alton was loaded with fruit, while in the next row trees of other kinds did not have one peach.-JAs. GAinEs, Vermillion County.

MARYland. I had a crop of peaches, mostly Alton, last year. I do not believe there was another peach in the county; also a full crop this year.-JoHn A. Bttrer, Montgomery County

MIssocri. Last fall I sold Alton peaches to fruit-dealers at 40 cents per dozen.- Elmer Granpin, St. Louis County.

NEW YORK. Alton is of highest quality; tree among the hardiest,

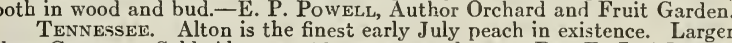
than Carman. Sold Alton at 50 cents per dozen,-Dr. F. L. Morris, Fayette County.

Texas. NIaking a record in the Panhandle; considered the best allound peach and most regular bearer.-F. T. RAMSEY, Travis County.

Utah is concerned will recommend it.-Sumner Gleason, Davis County.

\section{Stark Early Elberta * $(\mathrm{F})$}

For a number of years we have secured seeds from large orchards of Belle of Georgia, etc., and from them grown trees which we sent out as Select Seedlings, without budding, for trial purposes in the colder localities. Among a number sent to our friend and customer, Dr. Sumner Gleason, Davis Co., Utah, was one that for several years has produced very heavy crops of exceptionally large Elberta, but ripening a week to ten days earlier. This variety was watched closely, as for years growers have wanted a variety with the good qualities of Elberta but hardier, and of higher quality, and one ripening earlier, in order to make a longer Elberta season. We recognized its value and secured the entire right of propagation from the owner, to whom we had furnished complimentary, for trial, the original tree. The records made each succeeding season, in all parts of the country, have strengthened our faith in the variety; it has been tested from New York to California, from Michigan to Georgia, and with the exception of one grower it has been highly recommended. The fruit is fully as large as Elberta, of the same shape, as highly colored, and better in quality, and while Elberta ranks as one of the best shippers and keepers, Early Elberta is decidedly its superior in these respects. The tree is very hardy, is being planted extensively and is sure to be a money-maker. NNCS

Prices, same as Red Bird Cling on this page.

ARKansas. I have Elberta, Stark Early Elberta and Elberta Cling. Stark Early Elberta leads them all, it is the finest peach I ever ate. Beautiful on the outside and delicious on the inside. LATER: Early Elberta ripened about eight days before Elberta, and in shape a little oblong with a slight point to it. It is as fine a peach as I ever saw or ate.-P. B. DoBY, Clark County. 


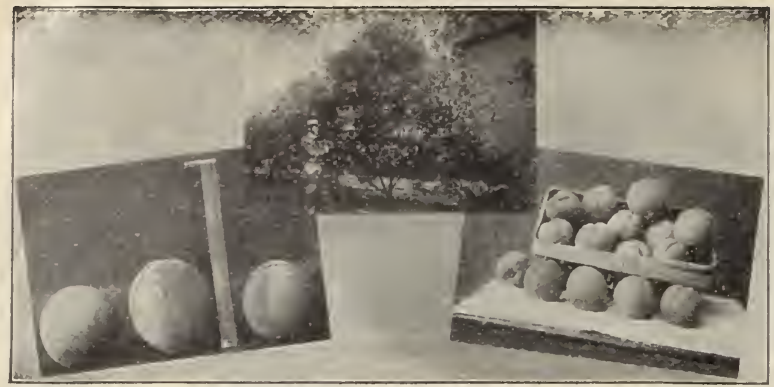

The original tree of Stark Early Elberta at Kaysville, Utah, and two groups of the fruit

California. You sent me in 1908, one Stark Early Elberta peach with your premium trees, and this last season it was loaded with the finest peaches I ever saw or tasted, and that is the reason why I want fifty more. LATER: Stark Early Elberta ripened about ten days ahead of the old Elberta. I had only onc two-year-old tree, but it was loaded and everyone that tasted the fruit pronounced it extra fine. I think it is the finest peach I ever tasted. the fruit pronounced it extra fue. Think it is the finest peach I ever tasted. I have six or seven varieties, such as you send out as premium trees; they are all growing fine and are loadcd with fruit every year, but that little
two-year Early Elberta has beat them all for fine fruit.-J. F. ANDERson, Tuolumne County.

GEORgIA. We fruited Stark Early Elberta again this season. All the specimens had been hit with hail, and, of course, were more or less defective, but the quality was superior to Elberta.-F. J. Berckmans Co., Fruitland Nurseries, Richmond County.

IlliNo1s. Two Early Elberta trees bore fine yellow, spicy fruit, and although not a full crop, there was more than was produced by fifty Elbertas in the same orchard. Ripened with Carman.-E. H. RIEHL, Illinois Experiin the same orch

Tennessee. I have the Alton, Elberta Queen, Elberta Cling, and Early Elberta. Early Elberta leads them all by odds. About two weeks earlier than Elberta Queen. We have a number of fine sorts, but was offered 50 cents more per bushel for the Early Elberta.-A. N. NesbitT, Humphreys County.

UтAн. I sent some Early Elberta to show keeping qualities. These were picked fully ripe September 17th; shipped to Salt Lake City and placed in cold storage. October $3 \mathrm{~d}$ they were shipped to Farmington, put on exhibition, and showed up better than Elbertas picked a week later. LATER, 1909: Am confident that Early Elberta will prove valuable very LATER, 1909: Am confident that Early Etrer wariety. J. H. Hale wrote far north, as with us it is hardier than any other variety. J. H. Hale wrote me that he took some Early Elberta home from Georgia and that they kept nearly twice as long as Elberta. He also says: "They are of great size and
brilliant color. Coming, as they do, a week ahead of Elberta and having brilliant color. Coming, as they do, a week ahead of Elberta and having such splendid color, they are just the thing we are looking for." LATER,
1910: I wish you could have seen the Stark Early Elberta orchard of Mr. A. G. Butcher, whose trees were loaded this year. No other peach approaches it in brilliant color and quality. Early Elberta has fruited with me now for eight years and is without exception the best yellow peach grown. Being an improved Elberta and coming in a week ahead of its parent, growers Being an improved Elberta and coming in a week ahead of its parent, growers of Elberta find it a welcome aldition to their orchard, and, when they want a peach for their own consumption, they go to the Early Elberta tree. Canneries say they prefer it because it keeps its shape and flavor in the can. UтAн. We sold about one hundred cases of Stark Early Elberta peaches the past season, and coming as they did, a little ahead of regular Elberta and having a brilliant color, they were repeaters, when once used they brought as high a price as any peach on the market.-DAvis Bro's Grocers), Salt Lake Count

UTAH. Stark Early Elberta is very fine; fully two weeks earlier than ordinary Elberta and much better in quality.-Robert S. Norturop,

Farmer's State Horticulturist, Salt Lake, Utah.
UTAH. I visited Dr. Gleason and saw Elberta and Early Elberta growing side by side. At the time of my visit, Early Elberta was ripe and in its prime, while Elberta was hard and green; fully two weeks before Elberta would have been as ripe. The habits of the Early Elberta tree
appear to me to be identical with the Elberta; fruit in external appearance appear to me to be identical with the Elberta; fruit in external appearance just the same, but in texture I believe Early Elberta has a little finer grain.
I believe Early Elberta is one of the best varicties introduced since the first Elberta came. It will no doubt play a very important part in sections such as we have here, where growers do not want many varieties, but must have early and late kinds. In Early Elberta one has all of the good qualities of Elberta, and the additional fcatures of early ripening.-E. IH. FAvor, Assistant Horticulturist, Utah Experiment Station.

UтAн. Have tested its shipping and keeping qualities thoroughly; without doubt it is the most valuablc addition to the commercial peach list made in recent years; an excellent shipper and as a

Washixgton. It is a pity there were not more Stark Early Elbertas in Chclan County the past season, as those fortunate enough to possess them found an open and cager market at advanced prices. The Stark Early some peach of finer texture and quality than Elberta, and because of its some peach of finer a veach.-T. H. Atrinsos, Chelan County.

\section{Elberta (Queen)*(F)}

Large to very large, yellow, with beautiful blush; firm, little coarse, but tender and good. While quality is not the highest, it has made more money for the orchardist than any other peach. Tree a rank, vigorous grower, healthy and fairly hardy-one of the most dependable. Elberta is the best known and most popular of all peaches and the standard market sort. Lengthen your Elberta season by planting June
Elberta, Stark Early Elberta, Late Elberta and October Elberta; by adding these to your Elberta plantings you will be able to put Elberta peaches on the market during the entire peach season. CS

One Year

\begin{tabular}{|c|c|c|c|c|c|c|c|c|c|c|c|}
\hline \multicolumn{4}{|c|}{$\mathrm{XXX}, 5$ to $7 \mathrm{fcet}$} & \multicolumn{4}{|c|}{$\mathrm{XX}, 4$ to 5 fect } & \multicolumn{4}{|c|}{$\mathrm{X}, 2$ to $\$$ feet } \\
\hline Fach & 10 & 100 & 1000 & Each & 10 & 100 & 1000 & Each & 10 & 100 & 1000 \\
\hline 40 & 3.50 & 30 & 230. & .35 & 3.00 & 25 & 190. & 30 & 2.50 & 22 . & 150. \\
\hline
\end{tabular}

WAsursicton. I purchased from you, two Elberta peach trees, and set them out the last of April 1907. Although this is not a peach country,
these trees are 10 fect high, and are regarded by the best fruit-growers of the country as an excellent specimen of what might be done in pcach culture in western Washington. I purchased trees a year ago from your nursery; the difference in the quality of trees, prices considered, will stand as an everlasting memorial to your honor in doing just exactly as you advertise.WALTER Fulcuer, Whatcom County.

\section{Illinois * (F)}

A peach of highest quality: large to very large, beautifully marked with bright red, remarkably free from rot and a splendid shipper. In quality and beauty it excels Champion. Tree extremely hardy. Originated near North Alton, Illinois, and is undoubtedly a Stark Heath-Washington cross, combining the many good points of its excellent parentage. NNCS

Prices, same as Red Bird Cling. See page 13.

NEW JERsey. Illinois peach is a wonder. I had seventeen quarts from two two-year trees and thinned half at that. Alton is good, but can't compare in productiveness or quality.-B. O. BoGERT, Bergen County.

\section{Stark Heath Cling *}

Clear white, slightly blushed; tender, melting, juicy and rich, with a most luscious flavor. A most profitable variety, readily selling at $\$ 3.00$ to $\$ 4.00$ per box on home markets. In our orchards it is one of the finest of the Heath strain and was also a favorite in the pioneer orchards of Judge James Stark. No market has ever been one-half supplied with Heath peaches. A favorite for canning and preserving. NCS

Prices, same as Red Bird Cling. See page 13.

\section{Krummel October *}

A magnificent peach-the best and most profitable late yellow freestone, which ripens about two weeks after Salway, but larger, of higher color and superior in quality to that sort, and a splendid keeper. On the St. Louis markets, where it attracted our attention, it has always commanded higher prices than Salway. Large, almost round, deep yellow with a dark carmine blush; very firm, fine texture, free from bitterness and extremely hardy. Tree is a very strong grower, vigorous, and healthy; fruit hangs very late-for weeks without decaying. One of the best peaches South, and in California no peach, not excepting Elberta, has proven more profitable. In Washington it is a gold-mine - all growers there are finding Krummel their best money-making late peach, and when the variety is grown largely, as it will be, it can be put on the eastern markets by the train-load. NNCS

Prices, same as Red Bird Cling. See page 13.

Arizona. Krummel is by far the best late peach we have and we consider it about the best yellow freestone, both for quality and as a moneymaker.- HaLL Bro's, Maricopa County.

California. Krummel has proven a better peach with me than Salway. It is very hardy, as far as frost is concerned. It is much larger than Salway, and on the same grounds is a little better color. Since they began bearing we have had two years of hcavy frost, in spring, and Krummel has stood the cold in good shape.-ROBERT PORTER, Santa Clara County.

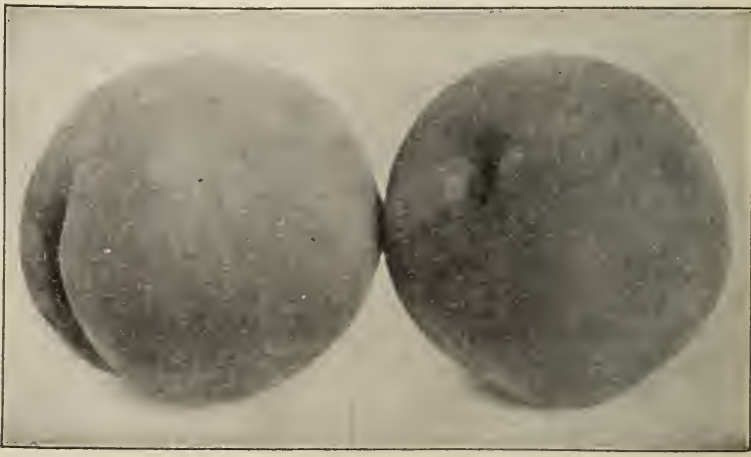

Krummel October-the best late peach 
Michigan. Both Bing and Lambert are large, late, and very desirable. The only fear I have is that such hard flesh varieties may crack in wet weather. Napoleon is also good. The best sour cherry is the Montmorency. -Prof. H. E. Van Deman, Ex-U. S. Pomologist.

\section{Lambert*}

Another fine sweet, originating in Oregon, and one of the largest of all cherries; dark, purplish red, turning almost jet black when ripe. Flesh firm, rieh, juicy; tree rugged, a strong grower and an enormous bcarer. The growing of the magnificent sweet cherries, Lambert, Bing, Royal Ann, etc., is a great industry only fairly well begun. There is an immense market for the fresh fruit, and when canned or preserved, the markets of the world arc open to the producer. NCS

Prices, same as Terry Early. See page 15.

\section{Napoleon *}

A beautiful and delicious large, yellow, sweet cherry, with a most attractive bright red blush; very firm and juicy. Napoleon is a magnificent eherry of largest size, an excellent shipper and famous as a variety for canning. Tree vigorous, strong growing and an enormous bearer. The hardiest and best of the yellow or light-colored sweet sorts, and very popular. NCS

Prices, same as Terry Early. See page 15.

Micmigan. Napoleon cherry the most productive of the yellow sweet chcrries; fruit large, heart-shaped, and mottlcd with red, texture firm, and quality fair. The trees are hardy and thrifty; one of the most profitable quality fair. The trees are hardy and thrifty; one of the
sweet cherries on trial.-Michigan Experiment Station.

\section{Royal Ann *}

A magnifieent, large sweet cherry, pale yellow, with a bright red cheek-one of the very best of the sweets; a splendid shipper and one of the finest for canning. To eat out of the hand it is unsurpassed. Flesh very firm and juicy; tree a rapid grower and an immense bearer. Cherry-growing for the canners, to say nothing of the great markets for the fresh fruit, is becoming a great industry in the West, where Royal Ann is planted by the hundreds of acres, along with Bing and Lambert. Cherry grows to perfection with less moisture than any other fruit; in Oregon some of the finest cherries are grown where the annual rainfall is only 12 inches, mostly in winter. The moisture is conserved by intensive cultivationthe system we practiced years ago in cherry-growing on the plains of Colorado. NC

Prices, same as Terry Early. See page 15.

Michigan. Very firm; valuable both for home use and market. Vigorous, productive-bore the heaviest crop of any sweet on triai.-MicHIgan Experiment Station.

\section{Suda Hardy *}

A very valuable late sort. The old tree in the garden of Capt. Suda, Louisiana, Mo., did not fail a full crop in 20 years. In yield it surpasses English Morello and IVragg; is hardier, has better foliage, is a better grower and is longer lived. NNCS

\begin{tabular}{|c|c|c|c|c|c|c|c|}
\hline \multicolumn{8}{|c|}{ One Year } \\
\hline \multicolumn{4}{|c|}{3 to 5 fcet } & \multicolumn{4}{|c|}{2 to 3 feet } \\
\hline Each & 10 & 100 & 1000 & Each & 10 & 100 & 1000 \\
\hline .50 & 4. 50 & 40. & $\ldots$ & .40 & 3.50 & 32. & \\
\hline
\end{tabular}

Two Ycar

\begin{tabular}{|c|c|c|c|c|c|c|c|c|c|c|c|}
\hline \multicolumn{4}{|c|}{ XXX, 5 to 7 feet } & \multicolumn{4}{|c|}{$X X,+$ to 5 feet } & \multicolumn{4}{|c|}{$\mathrm{X}, 3$ to + feet } \\
\hline Each & 10 & 100 & 1000 & Each & 10 & 100 & 1000 & Each & 10 & 100 & 1000 \\
\hline 60 & 5.50 & 50. & & 50 & 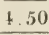 & 40 & & 40 & 3.50 & 32. & \\
\hline
\end{tabular}

Alarima. Have found Suda IIardy decidelly better than English Morcllo; these varietie.s grown sicle by side arc quite distinct and Suda is the best grower.-W. F. IlE⿺kes, Madison County.

Mlicmas. Suda liardy is more vigorous than others of the English Morello type; one of the most productive. Valuable for market.-MicuIjan Experiment Station.

\section{Apricot}

THE apricot ripens a month or more before the best early peaches come in, which explains the reason for the great demand and prevailing high prices. It should be planted in deep, rieh, dry soil; care slıould be taken to know that the sub-soil as well as the top soil is dry.

Aside from its value as a fresl fruit, the apricot has a fixed place on the list of fruits for drying and canning, for whieh purposes vast quantities arc used every year. With these two mcans of disposing of his erop, the orchardist who contemplates aprieot-growing need not hesitate because of the bugaboo of over-production-it is a myth.

\section{Superb *}

Another of the Russians-a hardy variety from Kansas. Quality, exeellent; flcsh, firm, sub-acid. Trce a vigorous grower, a heavy bcarer and hardy in wood and bud. Grown successfully in all peach regions and farther north. NNCS

One Year

\begin{tabular}{|c|c|c|c|c|c|c|c|c|c|c|c|}
\hline \multicolumn{4}{|c|}{$\mathrm{XXX}, 5$ to 6 feet } & \multicolumn{4}{|c|}{$\mathrm{XX}, 4$ to 5 feet } & \multicolumn{4}{|c|}{$\mathrm{X}, 3$ to $+\mathrm{fcct}$} \\
\hline Each & 10 & 100 & 1000 & Each & 10 & 100 & 1000 & Each & 10 & 100 & 1000 \\
\hline .50 & 4.50 & 40 . & & .40 & 3.50 & 32 & & .30 & 2.50 & 23 & \\
\hline
\end{tabular}

\section{Royal *}

Large, dull yellow, mottled with dark brown, juicy, rich and highly flavored. A great favorite for canning and drying. Highly esteemed and planted most extensively on the Pacific Coast. One of the best of the very best. CS

One Year

\begin{tabular}{|c|c|c|c|c|c|c|c|c|c|c|c|}
\hline \multicolumn{4}{|c|}{$\mathrm{XXX}, 5$ to 6 feet } & \multicolumn{4}{|c|}{$\mathrm{XX}, 4$ to 5 feet } & \multicolumn{4}{|c|}{$\mathrm{X}, 3$ to 4 feet } \\
\hline Each & 10 & 100 & 1000 & Each & 10 & 100 & 1000 & Each & 10 & 100 & 1000 \\
\hline .50 & 4.50 & 40. & 330. & .40 & 3.50 & 32 & 250. & .30 & 2.50 & 23. & 180 \\
\hline
\end{tabular}

\section{Tilton *}

One of the most dependable; a late bloomer, very hardy, exceedingly productive, and vigorous. Fruit very large, handsome, highly flavored, and melting. Splendid quality. Bears great erops when tender sorts are a failure. NCS

Prices, same as Royal on this page.

\section{Blenheim *}

This is one of the favoritc eommercial varieties of the Pacifie Coast, where it is planted very extensively. Color deep orange, sometimes slightly blushed; flesh tender, melting and of splendid flavor; tree vigorous and dependable. NCS

Prices, same as Royal on this page.

\section{Wenatchee Moorpark*}

Probably no other variety is in such constant and increasing demand throughout the western orchard regions. In the Wenatchee Valley of Washington, where it originated, it is being planted by the thousands-orchardists there will accept no other. While of the Moorpark family, Wenatchee Moorpark is both distinct and supcrior to all others. We propagate this famous apricot from a seleet strain. NCS

One Year

\begin{tabular}{|c|c|c|c|c|c|c|c|c|c|c|c|}
\hline \multicolumn{4}{|c|}{$\mathrm{XXX}, 5$ to 6 feet } & \multicolumn{4}{|c|}{$\mathrm{XX}, 4$ to 5 feet } & \multicolumn{4}{|c|}{$\mathrm{X}, 3$ to 4 feet } \\
\hline Each & 10 & 100 & 1000 & Each & 10 & 100 & 1000 & Each & 10 & 100 & 1000 \\
\hline .65 & 6.00 & 55. & 450 . & 55 & 5.00 & 45. & 350 . & 45 & 4.00 & 35. & 280. \\
\hline
\end{tabular}

Wasmington. Wenatchce Moorpark is the only one we can raise and sell here; thick flesh, small sced, fine quality, and good canner. It is far superior to all varieties I know.-M. Horas, the Applc King, Chclan County.

Wasmington. Wenatchee Moorpark is a distinct varjety, a laige apricot, and a fine shipper. It is a prolific bearcr, and ripens everiy all over: apricot, and a fine shipper. It is a prolific bearcr, and ripens everiy all over;
other apricots will be ripe on one side and green on the other. Trees are very hardy, and had fruit on them this year when all others failed. They very hardy, and had fruit on them this year when all others failed.
are far hardicr than any other apricot.-Oscar PIKE, Chelan County.

Wasmington. Far above any other variety $I$ have seen in size, and I don't belicve it can be excelled in flavor after canned. Trees bear hcavy and regularly and make enormous growth. You will not make any mistake if you promote the Wentachee Moorpark.-C. A. Leedy, Chelan County.

Wasurngtov. Wenatchee Moorpark is the only apricot-have grown them the sizc of Elbcrta peaches. When fully ripe they are as fine as any apricot grown, and bring from $\$ 10.00$ to $\$ 20.00$ a ton more than any other sort; hardy, beavy yielders, and regular bearers.-F. DANDo, Chelan Co. 


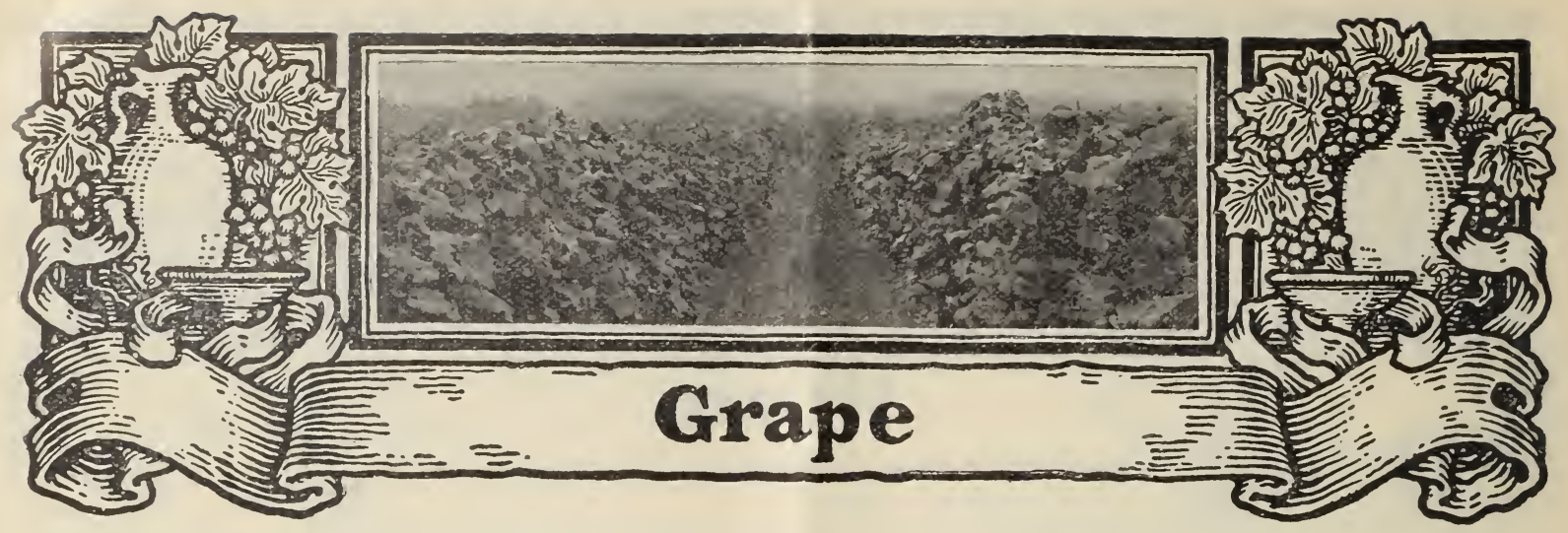

\section{$\underset{(\text { Trade-1Iark })}{\operatorname{Stark}}$ Eclipse}

The earliest, most valuable, and profitable black grape known. Of the Concord typc, but is far better, in evcry way, than that old standard varicty. Quality absolutely of the best-swect and very highly flavored as soon as colored. Bunch and berry a trifle smaller than Concord, but very handsome and compact, hanging well to the vine. Berry does not crack in wet weather, or scatter from the bunch; hangs wcll to the vinc long after ripe and in good condition, and is a good shipper. When allowed to hang on the vine until dead ripe, the flesh is rich, swcet, and melting, and parts readily from the seed. Vine hardy, healthy, and a vigorous grower, with exceptionally good foliage, which hangs later and remains grcen longer than almost any other variety. Should be planted with other varieties for cross-pollenization. Everything considered, Stark Eclipse stands at the very top in the list of early grapes and should be planted commercially for profit in all grape regions and made the most important part of the home arbor. It was originated by E. A. Riehl, of the Illinois Experiment Station, and is unquestionably the best of his many valuable creations. NCS

\begin{tabular}{|c|c|c|c|c|c|}
\hline \multicolumn{3}{|c|}{ One Year } & \multicolumn{3}{|c|}{ Two Year } \\
\hline Each & 100 & 1000 & Each & 100 & 1000 \\
\hline .40 & 30. & 210. & .50 & 40.00 & 300.00 \\
\hline
\end{tabular}

ILLiNors. Eclipse is a black grape, bunch and berry smaller than Concord, sweet and highly flavored as soon as colored, does not scatter from Concord, sweet and highly flavored as soon as colored, does not scatter from
bunch, or crack from wet weather. Vine a healthy grower, with exceptionally good foliage, which hangs on green later than almost any other variety known. Needs cross pollenization. It is earlier than any other variety
known to me and of the very best quality, hanging on the vines long after ripe in good condition.-E. A. RIEHL, Originator, Illinois Experiment Station.

I Livors. Eclipse is the best early grape that has been produced in this country so far as I have been able to learn from fifty years of experience fruits abundantly even on young vines, and the quality is A-1, and it hangs on the vine as well as any grape I have ever tested. Ships as well as Ives or Catawba. LATER: I have watched the Eclipse grape closely for ten years, and the more I see of it the better I like it. It is a good reliable grower, has
good foliage that hangs on well and ripens up its wood to the tips, is a good

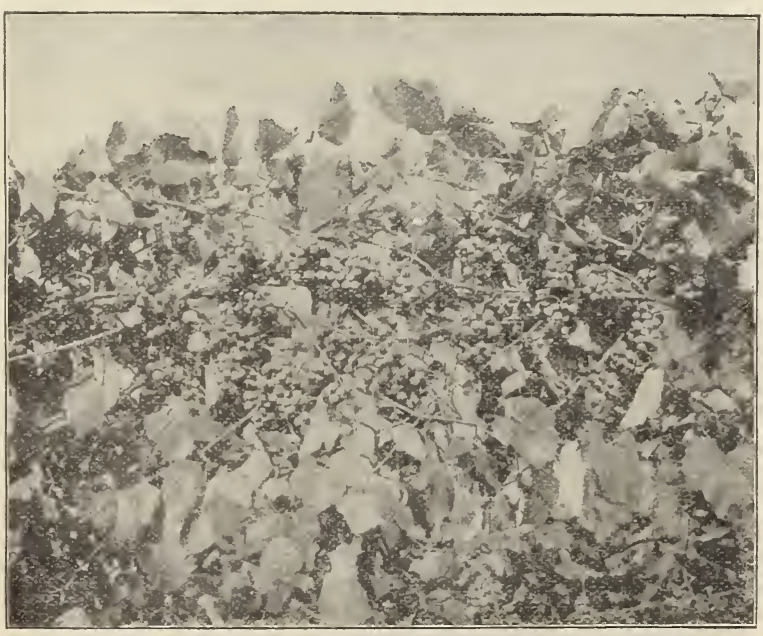

Stark Eclipse in the vineyard of E. II. Riehl, Alton, Illinois reliable fruiter, but it needs a few vines of some early kinds planted with it, as it is not entirely self fertile. A few vines of Moore Early or King Philip will insure a fine crop or it does here. As to its quality it is as good as the Green Mountain; this I have tested by handing a bunch of it to an expert in the dark and then a bunch of Green Mountain and he could not tell the difference. As grown here, it is almost as large in bunch and berry as the Concord. And the earliest grape I have ever seen.-Geo. W. Exicotr, Pulaski County.

Mrchigan. I have the Eclipse and have tested its fruit, which is fine and very early. The vine seems hardy with splendid foliage.-HeNrY Purfield, Washtenaw County.

Missouri. Top prices are paid for fruit which is put on the market just a ripening of the general crop. This is a great advantage Eclipse has-it is very early and brings top market prices. It is very often the case that early varieties of fruit are not quite so good in quality as the varieties which come later. In this, Eclipse is an exception. Early as it is, it gets its remarkably pleasant flavor just as soon as it is colored and is much sweeter and of better quality than other black grapes, such as Concord.-STARK Bro's.

NEW York. Vines of Eclipse have fruited at this station for several years. Eclipse is very similar to Concord, differing chiefly in earliness and in a higher degree of quality. The vines make a most satisfactory growth, appear to be hardy, healthy and productive.-O. M. TAYLOR, Foreman in Horticulture, New York Experiment Station.

New YorK. The foliage of Eclipse is equal to the Concord or any other grape grown, a week earlier than Moore's Early, quality first-class; in fact, the best early grape up to date. Every one of the growers around here who have tested Eclipse agree that it is a first-class early grape.Fred B. Lewis, Chautauqua County.

OKLAномA. Eclipse is very promising. I presume that this is the same Eclipse that was originated by Mr. E. A. Riehl, of Alton, Illinois. It is a very good grape; not so high quality as the King Philip.-N. O. Bоотн, Horticulturist, Agricultural and Mechanical College, Stillwater, Oklahoma.

\section{Stark King Philip * (Trade-Mark)}

Originated by N. B. White, Norfolk Co., Massachusetts, "the Burbank of the Bay State." It is a hybrid of the Labrusca, Riparia, and Vinifera-the three best species to combine for a table grape. Flesh tender, fine-grained, vinous, sprightly, sweet, and refreshing; seeds readily separate from the pulp, keeps well and is a fine shipper. Mr. White describes the grape as follows: "Hardy, early, and vigorous; has so far withstood New England winters without protection and is as free from mildew as are Concord and Worden. The vine mostly resembles the native species, while the fruit resembles the foreign species, having the appearance and quality of Black Hamburg. It is the most dclicious grape, a long keeper and a good shipper. It seldom has more than one seed and is perfectly tender to the center. Unequaled by any other grape." Hon. G. B. Brackett, U. S. Pomologist, say's that Stark King Philip is the highest quality for dessert and will be a great market variety; also that it is perfectly hardy in Massachusetts and that he has great faith in it. No varicty we have ever introduced has impressed us more favorably. A marvelous and wondrous grape, worthy of the attention of amateurs, connoisseurs, and commercial growers evcrywhere. Our faith in the grape is shown by our investment of a large sum of money, acting upon the recommendation and endorsement of some of the best fruit-growing authorities in the United States. Stark King Philip has passed the experimental state, having been fruited from the Atlantic to the Pacific Coast; in cvery case it lias becn found to be remarkably hardy. Every planter should plant a few Stark King Philip. NCS

\begin{tabular}{c|c|c||c|c|c}
\multicolumn{3}{c}{ One Year } \\
\hline Each & 100 & 1000 & Each & 100 & 1000 \\
\hline 75 & 50.00 & 400.00 & 1.00 & 80.00 & 650.00
\end{tabular}

Iow $\Lambda . \Lambda \mathrm{m}$ sure you will be interested in the behavior of Stark King Philip grape. They were planted early and made a fine growth before th coming of the great storm and severe freeze in April. All new growth in 
all other vines (twenty-eight varieties) was killed back to the old wood and in some varieties the vines were killed to the ground. King Philip came through the ordeal with nothing but a few leaves destroyed. The vines have made a splendid growth, best of all the varieties, with no spindling canes but every one plump and full to the tip.-Tros. F. RIGG, Horticultural Experiment Station.

Massachusetrs. I visited the home place of N. B. White, Norwood, Mass., during both the growing and fruiting seasons and believe Stark King Philip to be the very best black grape grown to-day. I have known the grape since its origin; have watched its developments and rejoice with you grape since its origin, have watcher its developments and rejoice with you over its great merits. The vine is a vigorous, rampant grower, has hardy, strong cancs and is very productive. Foliage thick, leathery, large and healthy, bunches large, fine shape, well shouldered and attractive; berries The quality is superb- the very best, juicy, rich and delicious. It is the best black grape.-ABeL F. STevens, Grape Specialist, Norfolk County.

NEW York. Your Stark King Philip has the most promising, strongest and most vigorous foliage of any grape I have come in contact with.F. B. Lewis, Chautauqua County. (Mr. Lewis has had more experience in the propagation of new and rare grapes than any other propagator in the Grape Belt of New York.-Stark Bro's.)

\section{Campbell Early*}

Of the Concord type, but much earlier, larger, and of better quality when thoroughly mature. Attains full color before ripe, but is often marketed in an unripe condition, which has injured its reputation for quality. The introducer says Campbell Early, with him, bears about three times the amount of fruit that Moore Early bears. F. B. Lewis, of Chautauqua Co., New York, who knows more about its introduction than any other man save the introducer, says it is destined to be one of the most valuable commercial sorts, and that it should be extensively planted in all grape regions. Prof. L. R. Johnson, of Cape Girardeau Co., Missouri, one of our best grape authorities, pronounces it the best of its season, and for proo exhibited at the meeting of the Missouri State Board of Horticulture, specimen fruit equaling any grown in the Chautauqua grape belt. It has very remarkable keeping qualities, and as a shipper is second to none. The vine is a strong, vigorous grower, hardy, with thick, healthy, mildew-resisting foliage, and perfect self-fertilizing blossoms. Both bunch and berry are very large; hangs well after becoming ripe, and has a long ripening season. NCS

\begin{tabular}{c|c|c||c|c|c}
\multicolumn{3}{|c}{ One Year } \\
\hline Each & 100 & 1000 & Each & 100 & 1000 \\
\hline .25 & 20.00 & 140.00 & .35 & 30.00 & 210.00 \\
\hline
\end{tabular}

\section{Moore Early *}

A black grape that in quality is similar to Concord, but is considerably larger and is a good shipper. Vine is healthy, hardy and succeeds over a wide range of territory, thriving wherever Concord will grow. In the West, as well as in the East, it is being planted heavily, and from a profit standpoint it should be planted even more largely in all grape regions. A valuable and profitable variety. NCS One Year

\begin{tabular}{c|c|c||c|c|c}
\hline Each & 100 & 1000 & Each & 100 & 1000 \\
\hline .20 & 15.00 & 120.00 & .25 & 20.00 & 150.00 \\
\hline
\end{tabular}

\section{Diamond *}

Delicate greenish-white with a rich yellow tinge when fully ripe-one of the most satisfactory of its class and season. Its quality and beauty make it popular, while its hardiness, vigor, and productiveness make it ideal in the vineyard. NCS

Prices, same as Moore Early on this page.

\section{Barry *}

One of the very finest of all the Rogers hybrids; black, very attractive, both in bunch and berry; high quality, and a splendid keeper. Vine vigorous, healthy, hardy, and productive-one of our best black grapes. NCS

One Year

\begin{tabular}{c|c|c||c|c|c}
\hline Each & 100 & 1000 & Each & 100 & 1000 \\
\hline .40 & 35.00 & $\ldots$. & .50 & 45.00 & $\ldots$. \\
\hline
\end{tabular}

\section{Herbert *}

A Rogers hybrid, and a superior black grape-one of the finest for table use. Fruit keeps remarkably well-long after Concord has gone, is of very highest quality and is a good shipper. NCS

Prices, same as Barry on this page.

\section{Stark Delicious *}

From the experimental vineyards of E. A. Riehl, Illinois' greatest grape authority. Color light red, large bunch, medium berry; has proven hardy and dependable wherever tested. Several years ago Mr. Riehl sent specimen bunches to us and they were undoubtedly the most beautiful red grape we have ever seen-the quality was perfection. Being anxious to introduce this variety we investigated its merits thoroughly and we now confidently believe that Stark Delicious in due time will rank as one of the great standard varieties. Mr. Riehl says that vineyardists did not plant more red grapes because there were really no high-quality red grapes until the Stark Delicious. Vines hardy and productive. NCS One Year

\begin{tabular}{c|c|c||c|c|c}
\hline Each & 100 & 1000 & Each & 100 & 1000 \\
\hline 1.00 & 90.00 & $\ldots$ & $\ldots$ & $\ldots$ & $\ldots$ \\
\hline
\end{tabular}

\section{Niagara *}

A hardy white grape that succeeds almost everywhere. Bunch is large and very handsome, and when fully ripe is melting and sweet, with a flavor and aroma peculiarly its own. E. A. Riehl, the well-known Illinois Viticulturist, says it is the best of all grapes-more than a White Concord-and the white grape for the millions. NCS

\begin{tabular}{|c|c|c|c|c|c|}
\hline \multicolumn{3}{|c|}{ One Year } & \multicolumn{3}{|c|}{ Two Year } \\
\hline Each & 100 & 1000 & Each & 100 & 1000 \\
\hline .15 & 6.50 & 50.00 & .20 & 9.50 & 65.00 \\
\hline
\end{tabular}
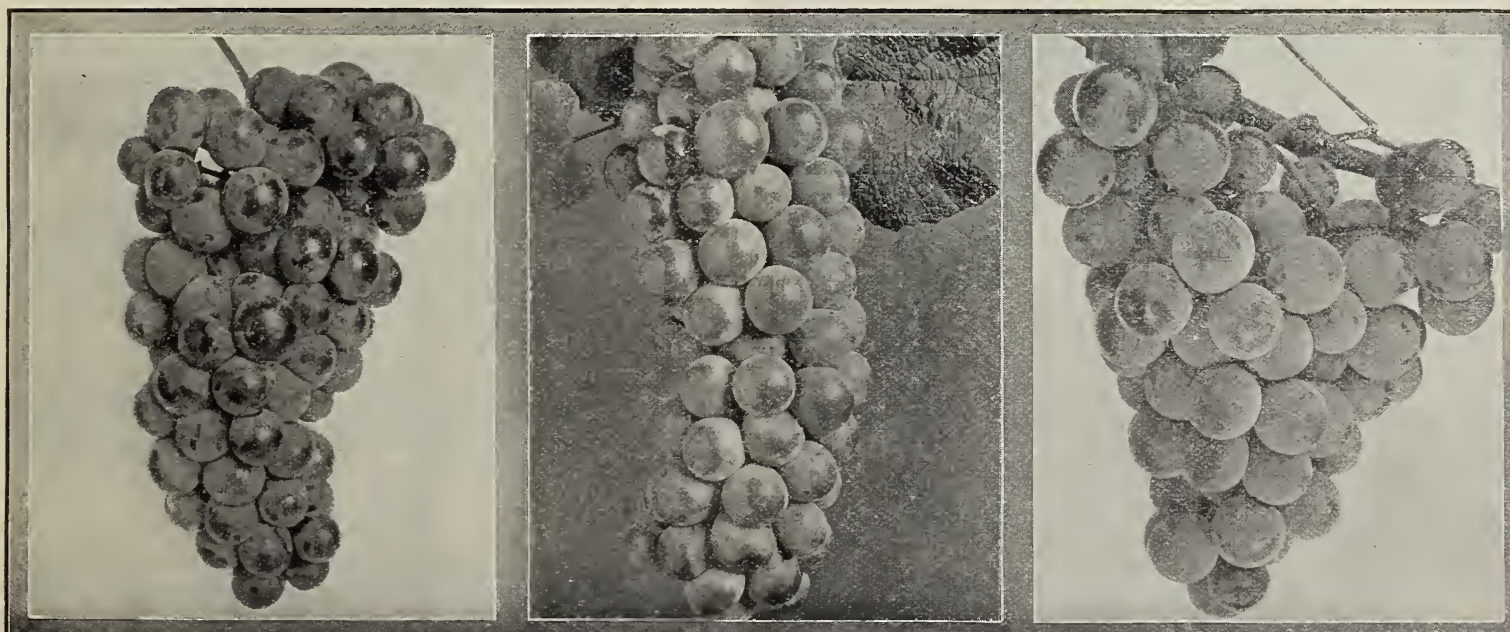


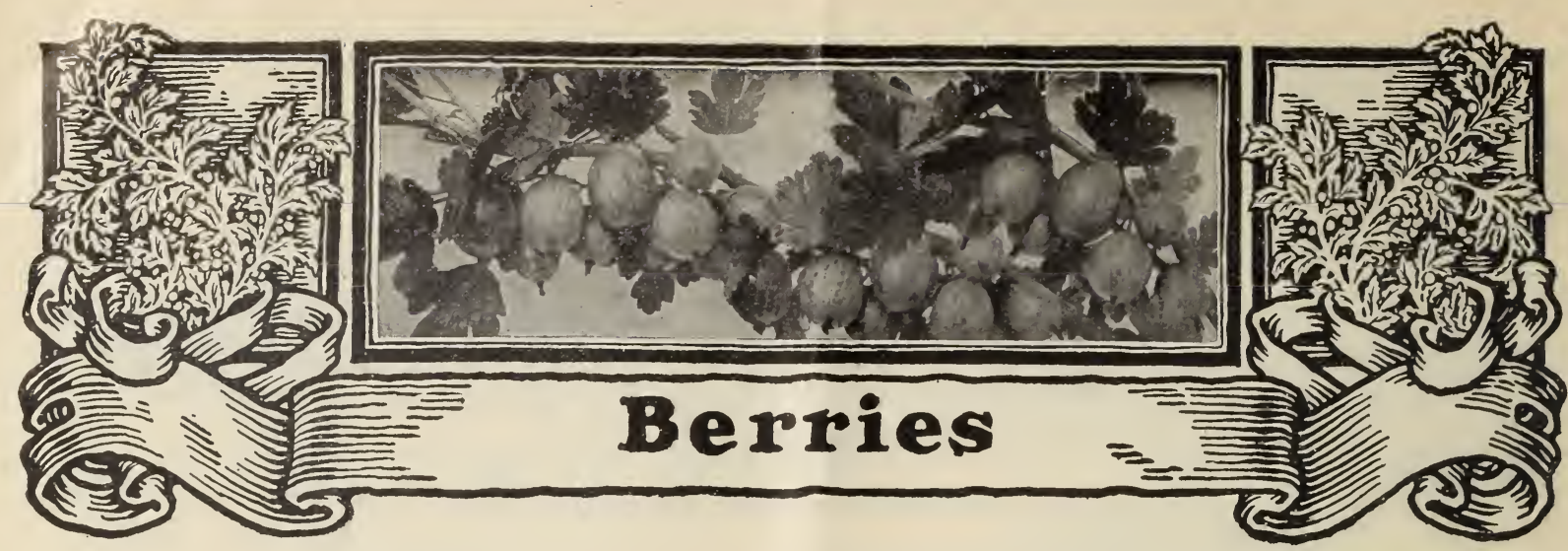

\section{Blackberry}

THE small bush fruits, the blackberry, raspberry, dew1 berry, currant and gooseberry, thrive almost everywhere. An assortment of these should go into every home garden; even the small back yard of the city dweller affords ample space to grow them in sufficient quantities for the average family. At trifling cost an assortment can be purchased which will, each season, produce more than enough wholesome, healthful, delicious fruit to repay the cost of the plants.

\section{Illinois * \\ (Trade-Mark)}

Originated by E. A. Riehl. This blackberry is undoubtedly one of the largest, hardiest, highest in quality, and most profitable of the early kinds; ripens shortly after Early Harvest, but matures its crop more quickly. Mr. Riehl's description of the variety follows:- "Some twenty years ago I noticed in a fence corner by the road, a clump of blackberries that were earlier, larger, and better than any I had ever seen, and after noting its good behavior for a few seasons I took up twentyeight to give them a trial under cultivation. They bore so well, were so large, and of such excellent quality that I replaced a patch of Kittatinny where the latter had died from rust. Having found them better than all others, from this time on we grew no other, except that I tested all new sorts as they were introduced. Up to this time there has been nothing equal to it in all desirable points. Has never been winter-injured since I have had it." Illinois is now being grown all over the country and as its value becomes known, the demand for the vines is increasing. We unhesitatingly recommend it. NCS

\begin{tabular}{c|c|c}
\hline 10 & 100 & 1000 \\
\hline 1.50 & 8.00 & 50.00 \\
\hline
\end{tabular}

INDIANA. Will excite the admiration of any grower, on account of uperior quality and extreme earliness. A hundred times more valuable than Early Ilarvest.-J. F. Grass, Indiana.

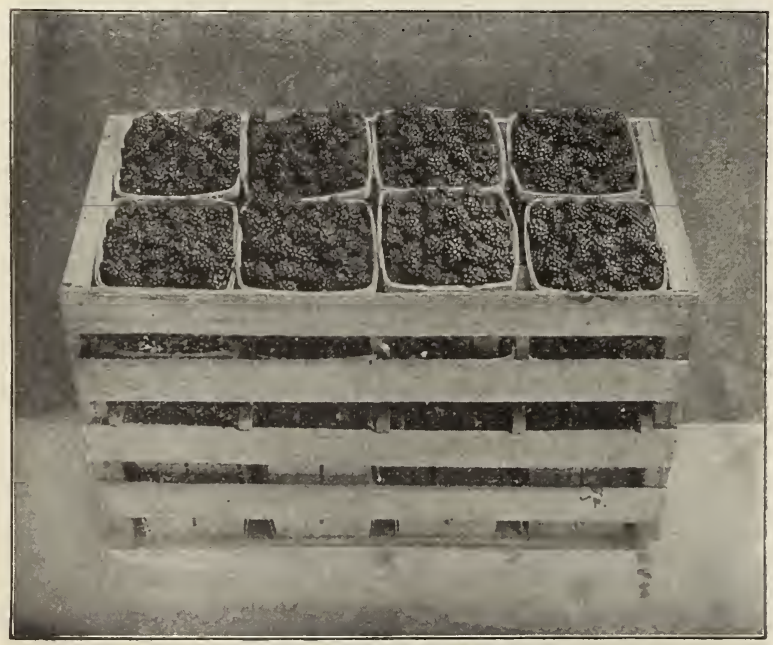

A crate of Blowers Blackberry
ILLinors. Good size, quality the best, promising.-ARTHUR BRYANT, Illinois Horticultural Society.

\section{Blowers *}

The hardiest of all blackberries; very large, jet black, exceedingly sweet, fine quality, and handsome; productive, and a good shipper. NCS

\begin{tabular}{c|c|c}
\hline 10 & 100 & 1000 \\
\hline 1.25 & 7.00 & 30.00 \\
\hline
\end{tabular}

\section{Ward *}

Originated in New Jersey. A fine berry of very best quality and a very strong grower. CS

Prices, same as Blowers on this page.

This seems to be without doubt the best variety we have tested on a large scale. Most all varieties of the different fruits have one or more weak points, but if I were asked to name a fault of the Ward, I could not do it. -E. H. RIEHL, in Colman's Rural World, November 15, 1908.

\section{Raspberry}

\section{St. Regis *}

Color bright crimson, firm, rich and delicious, and a splendid shipper. Of iron-clad hardiness-the canes will endure the severest cold without injury. Everbearing and wonderfully prolific. NCS.

\begin{tabular}{c|c|c}
\hline 10 & 100 & 1000 \\
\hline 1.50 & 10.00 & 75.00 \\
\hline
\end{tabular}

\section{Manitou *}

A very large and handsome firm red berry of perfect raspberry quality that ripens through a long season. One of the hardiest and best of the reds. NNCS

\begin{tabular}{c|c|c}
\hline 10 & 100 & 1000 \\
\hline 1.25 & 7.00 & $\ldots$ \\
\hline
\end{tabular}

ILLINors. Manitou is in the same class with raspberries that the Delicious is with apples. - George W. ENDicotr, Pulaski County.

ILLINols. Manitou is of exceptional hardiness and vigor; most productive of any, large, firm, bright and of most excellent quality. Easily the best variety on the market.-E. H. RiEHL, Illinois Experiment Station.

\section{Shippers' Pride *}

Red, and one of the finest raspberries - the best shipper of all the reds. Berry is of good size and good color; bush hardy and a vigorous grower. Making a splendid record in Minnesota and other northern states. NNCS

Prices, same as Manitou on this page.

Minnesota. I consider it superior as a commercial grower to any of the reds, inasmuch as it is hardy, early to late, good size and color, very vigorous grower and best shipper on the market, and, best of all, can be picked from the stem several days before ripe, and yet have obtained good color, and can be shipped anywhere.-A. W. Ricusanson, Wright County.

\section{Herbert*}

A raspberry of splendid quality, originating in Canada. Fruit large, bright to deep red; a strong grower, hardy, and very productive. NCS

Prices, same as Illinois blackberry on this page. 
Canada. Deep red, moderately firm, sprightly, juicy, good flavor, guality good. Best red raspberry tested here. May displace Cuthbert.Ottawa, Caxada, Experiment Station.

\section{New American *}

An ideal blackcap for market purposes; berry is large and very firm; bush healthy, very strong and hardy. The originator claims New Amcrican to be the very best blackcap in propagation. Comes from Ohio. NNCS

Prices, same as Shippers' Pride. See page 20.

\section{Currant}

\section{London Market*}

Brilliant red, good quality; a strong, rugged grower, less injured by leaf diseases, twig borer, etc., than any other. NCS

\begin{tabular}{c|c|c||c|c|c}
\multicolumn{3}{|c}{ One Year } \\
\hline Each & 100 & 1000 & Each & 100 & 1000 \\
\hline .10 & 6.00 & 40.00 & .15 & 8.50 & 50.00 \\
\hline
\end{tabular}

\section{White Imperial *}

The best white currant; sweet and rich, fine for dessert; cntirely satisfactory in growth and foliage. Hardy and productive. NCS

\begin{tabular}{c|c|c||c|c|c}
\multicolumn{3}{c}{ One Year } \\
\hline Each & 100 & 1000 & Each & 100 & 1000 \\
\hline .20 & 10.00 & 75.00 & .25 & 15.00 & 120.00 \\
\hline
\end{tabular}

\section{Perfection *}

One of the very best currants; beautiful, bright red, rich and mild, with few seeds. A great bearer; foliage remarkably healthy. NCS

\begin{tabular}{c|c|c||c|c|c}
\multicolumn{3}{|c}{ One Year } & \multicolumn{3}{c}{ Two Year } \\
\hline Each & 100 & 1000 & Each & 100 & 1000 \\
\hline .25 & 15.00 & 120.00 & .30 & 20.00 & 170.00 \\
\hline
\end{tabular}

\section{Diploma *}

Red; very large, good quality; a strong grower and valuable for both home and market. Was awarded a gold medal at the World's Columbian Exposition as the largest and best currant. NCS

\begin{tabular}{c|c|c||c|c|c}
\multicolumn{3}{c}{ One Year } & \multicolumn{3}{c}{ Two Year } \\
\hline Each & 100 & 1000 & Each & 100 & 1000 \\
\hline .40 & 30.00 & 210.00 & .50 & 40.00 & 300.00 \\
\hline
\end{tabular}

\section{Wilder *}

Large, brilliant red, fine quality. One of the strongest growers and most productive; fruit hangs on the bushes in fine condition after ripening; valuable. NCS

Prices, same as White Imperial on this page.

\section{Dewberry}

\section{Austin *}

Very early, of good quality, and one of the best for the South and Southwest. Not hardy North. CS

\begin{tabular}{c|c|c}
\hline Each & 100 & 1000 \\
\hline .10 & 4.00 & 18.00 \\
Premo $*$
\end{tabular}

Jet black, firm and good. One of the hardiest. Should be planted with Lucretia, as bloom is imperfect and needs a pollenizer. NC

Prices, same as Austin on this page.

\section{Lucretia *}

The best and most dependable dewberry. Large, jet black, highly flavored and hardy. A profitable market sort. NCS

Prices, same as Austin on this page.

\section{Gooseberry}

\section{Houghton *}

The best payer of all gooscberries. Small, dark red, thin skinned; juicy, sweet, and of excellent flavor. NNCS

\begin{tabular}{c|c|c||c|c|c}
\multicolumn{3}{c}{ One Year } \\
\hline Each & 100 & 1000 & Each & 100 & 1000 \\
\hline .10 & 7.00 & 50.00 & .15 & 9.00 & 65.00 \\
\hline
\end{tabular}

\section{Chautauqua *}

Yellowish-white; sweet, rich, and of good quality. Yields great crops, is vigorous, and more dependable than Industry and other English sorts. NNCS

\begin{tabular}{|c|c|c|c|c|c|}
\hline \multicolumn{3}{|c|}{ One Year } & \multicolumn{3}{|c|}{ Two Year } \\
\hline Each & 100 & 1000 & Each & 100 & 1000 \\
\hline .30 & 25.00 & 200.00 & 40 & 35.00 & 300.00 \\
\hline
\end{tabular}

\section{Pearl *}

A little larger and more prolific than Downing; light yellowish-green; quality good. Has many good qualities to recommend it. NCS

\begin{tabular}{|c|c|c|c|c|c|}
\hline \multicolumn{3}{|c|}{ One Year } & \multicolumn{3}{|c|}{ Two Year } \\
\hline Each & 100 & 1000 & Each & 100 & 1000 \\
\hline .20 & 15.00 & 120.00 & .25 & 20.00 & 170.00 \\
\hline
\end{tabular}

\section{Carman *}

Large golden-yellow; very productive, healthy, hardy, and remarkably free from mildew. NCS

\begin{tabular}{c|c|c|c|c|c}
\multicolumn{3}{c}{ One Year } \\
\hline Each & 100 & 1000 & Each & 100 & 1000 \\
\hline .40 & 30.00 & & .50 & 40.00 & \\
\hline
\end{tabular}

\section{Portage *}

One of the handsomest and best; largc, of good quality, free from mildew, a good grower, and productive. NCS

Prices, same as Carman on this page.

\section{Josselyn *}

Probably the best of the large-fruited American sorts; a strong, vigorous grower, hardy, and a wonderful cropper; bright green, healthy foliage almost free from mildew. Berries oblong, smooth, pale red when ripe, and very highly flavored. NNCS

\begin{tabular}{c|c|c||c|c|c}
\multicolumn{3}{c}{ One Year } & \multicolumn{3}{c}{ Two Year } \\
\hline Each & 100 & 1000 & Each & 100 & 1000 \\
\hline .20 & 10.00 & 75.00 & .25 & 15.00 & 110.00 \\
\hline
\end{tabular}

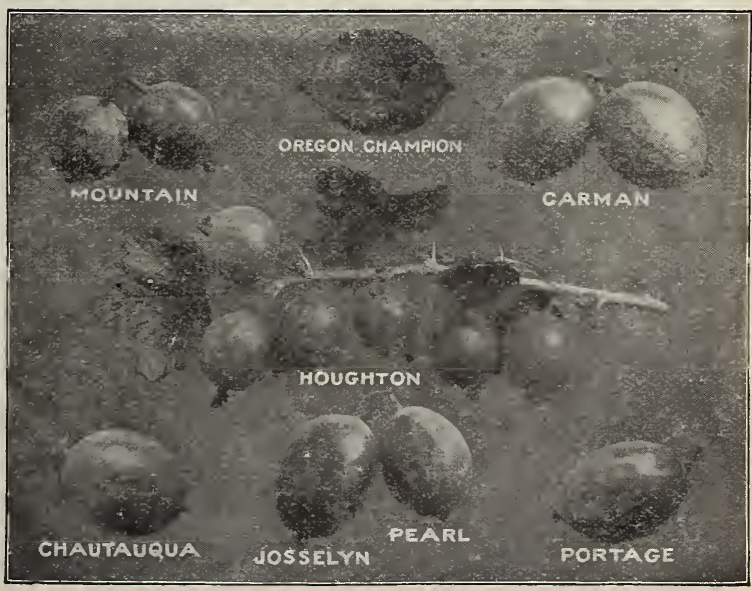

The best Gooseberries grown 


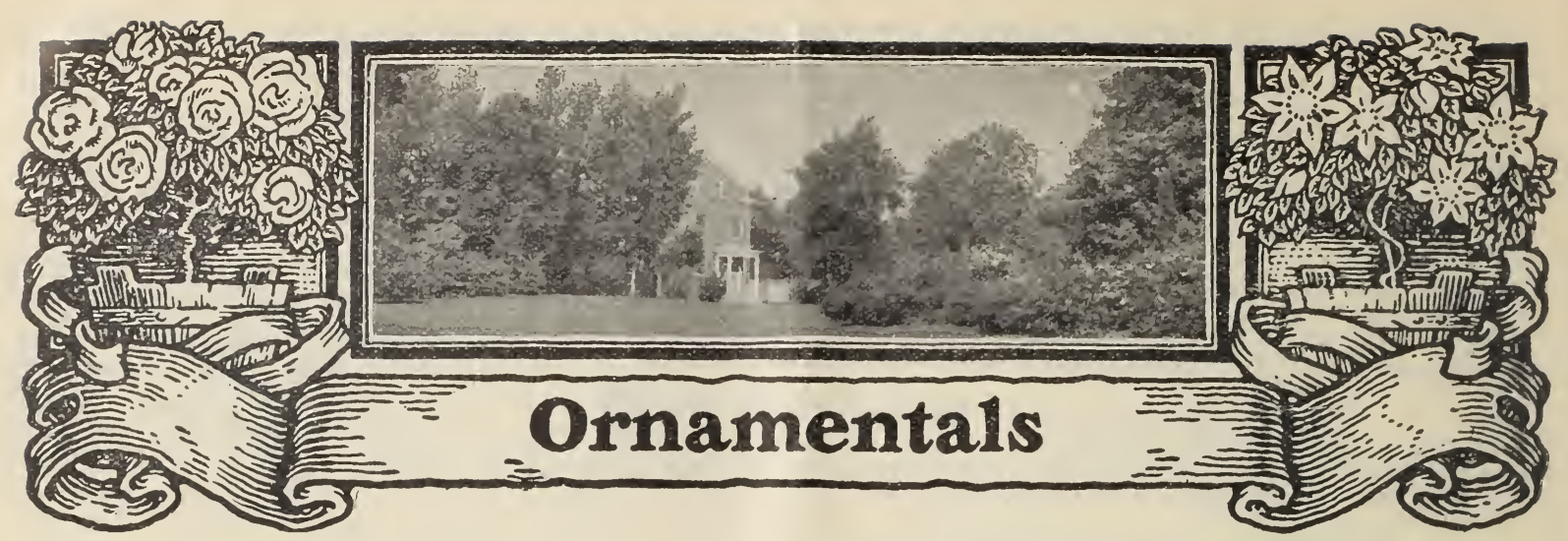

\section{Roses}

\section{Burbank}

(IIybrid Bourbon.) A large rose of a soft cherry-rose color. Blossoms are borne in the greatest profusion and are very durable. As a continuous bloomer Burbank is unsurpassed.

\begin{tabular}{c|c|c}
\multicolumn{3}{|c}{ Two Year } \\
\hline Each & 100 & 1000 \\
\hline .40 & 30.00 & 200.00 \\
\hline
\end{tabular}

\section{Eugene Furst}

(Hybrid Perpetual.) The blackest, richest, and most glorious of all the dark roses. Color, crimson with shadings of deep black-red; blossoms large, shapely, velvety, and very fragrant. We cannot recommend this superb rose too highly.

\begin{tabular}{c|c|c}
\multicolumn{3}{c}{ Two Year } \\
\hline Each & 100 & 1000 \\
\hline .50 & 40.00 & \\
\hline
\end{tabular}

\section{General Jacqueminot}

(Hybrid Perpetual.) This is an old-time favorite and one of the most desirable red roses. The color is a deep, rich, velvety crimson; the flower is remarkably beautiful, both in bud and full blossom. One of the hardiest.

\begin{tabular}{c|c|c}
\multicolumn{3}{|c}{ Two Year } \\
\hline Each & 100 & 1000 \\
\hline .35 & 25.00 & 180.00 \\
\hline
\end{tabular}

\section{Helen Gould}

(IIybrid Tea.) Beautifully shaded dark carmine, the color much resembling American Beauty; magnificent in bud and full; perfectly double flower. Considered by everyone as onc of the best everblooming roses introduced. Hardy.

Prices, same as Burbank on this page.

\section{J. B. Clark}

(Iybrid Tea.) Deep scarlet, shaded with darkest crimson. Here is a rose that every rose-lover should have. Its wonderful beauty has been the sensation among the up-to-date growers; its great size and splendid, dazzling beauty will attract more attention than any other rose in your garden. Hardy far north. Plant it sure.

Prices, same as Eugene Furst on this page.

\section{Paul Neyron}

(Hybrid Perpetual.) The largest and most showy rose in cultivation. An exceptionally good grower, making straight shoots of 4 or 5 feet in one season; each shoot is tipped with a great handsome flower, often 5 inches in diameter; very double and full, finely scented, and they are produced all summer long.

Prices, same as General Jacqueminot on this page.

\section{Snow Queen}

(Hybrid Perpctual.) The grandest, handsomest of all white roses, "The White American Beauty." One of the hardiest and most vigorous, and its immense, glorious, pure waxy-white blossoms make it an object of admiration in every collection. Without the shadow of a doubt, it is the greatest white hybrid perpetual rose ever introduced, and is one of the most talked-of varieties of recent years. By all means, make room for at least a few plants of this beautiful rose.

Prices, same as Eugene Furst on this page.

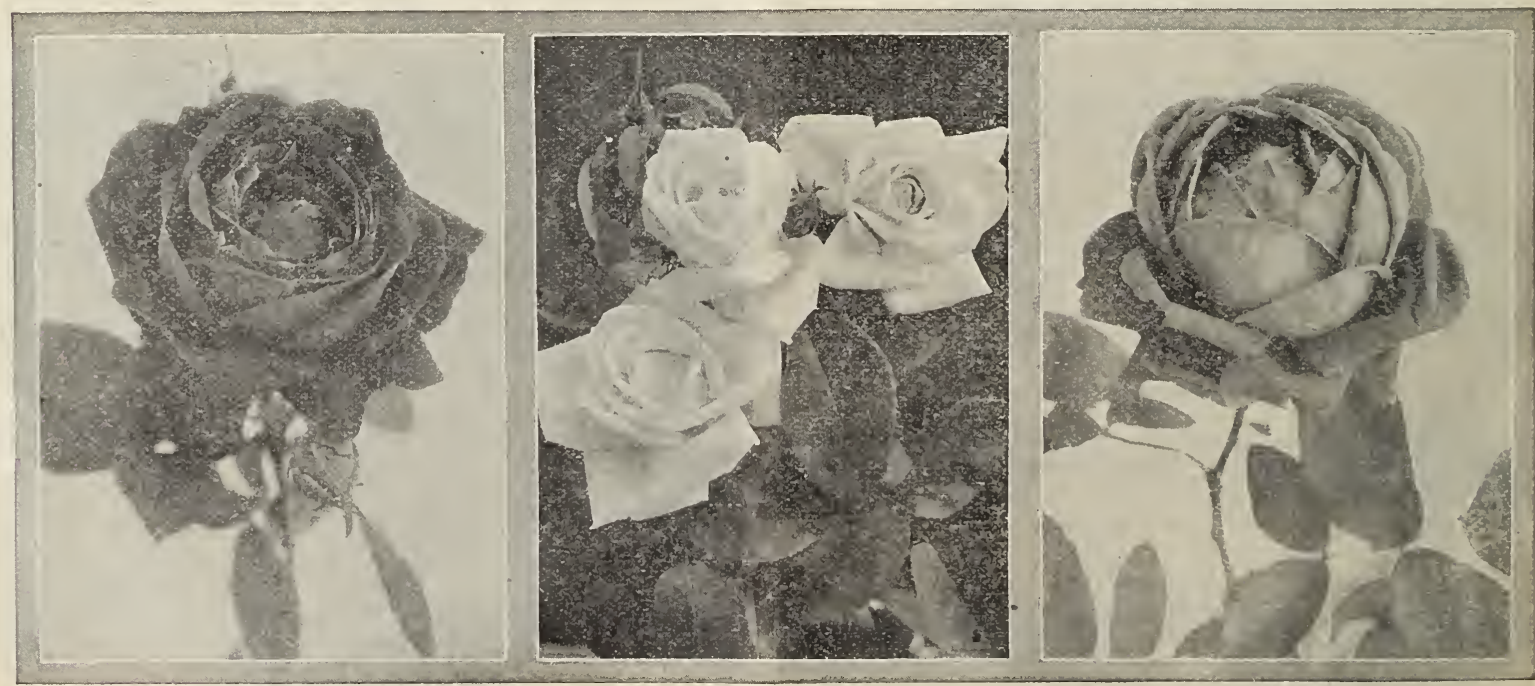




\section{Violet Blue}

(Rambler) Simply a seedling of Crimson Rambler which blossoms with violet-blue flowers; very vigorous and hardy. This is the greatest rose creation of the 20 th century.

\begin{tabular}{c|c|c} 
& \multicolumn{3}{c}{ Two Year } \\
\cline { 2 - 3 } Each & 100 & 1000 \\
\hline .75 & 65.00 & \\
\hline
\end{tabular}

\section{Hedge Plants}

\section{Barberry, Japanese}

A blossoming shrub, very dense in growth, with drooping branches. Flowers yellow, followed by a profusion of scarlet berries which hang through the greater part of the winter. In autumn, the foliage turn scarlet and gold.

\begin{tabular}{c|c|c}
\hline Each & 100 & 1000 \\
\hline .30 & 20.00 & 180.00 \\
\hline
\end{tabular}

\section{Privet, Amoor River}

One of the very best privets, slim and graceful in growth, makes an excellent hedge and is hardy. Foliage retains its color, and hangs well into the winter.

\begin{tabular}{c|c|c||c|c|c}
\hline \multicolumn{3}{|c||}{18 to 24 inches } & \multicolumn{3}{|c}{2 to 3 feet } \\
\hline Each & 100 & 1000 & Each & 100 & 1000 \\
\hline .12 & 8.00 & 50.00 & .15 & 10.00 & 60.00 \\
\hline
\end{tabular}

\section{Privet, California}

The most popular of all ornamental hedges. Not only is it beautiful for hedges, but for grouping on lawns it is magnificent, as it can be sheared to any desired shape. Its rich dark-green foliage is carried far into the winter. Hardy and easily grown. When planted as a hedge, and when a very dense effect is desired, plant two or three rows, about 8 inches apart, with the plants 1 foot to 18 inches apart in the rows and alternated. Keep well sheared back. A perfect and most beautiful hedge will be the result.

Prices, same as Amoor River Privet on this page.

\section{Spirea, Van Houttei}

It would be hard to select a more beautiful shrub for border planting along walks or drives, or for planting on the lawn singly or in clusters, than Bridal Wreath. It makes a spreading growth, 4 to 6 feet high, and during the season is a solid mass of the most delicate snow-white flowers imaginable, with a faint but pleasing perfume. The planting scheme of the pretentious home or of the lowliest cottage cannot be complete without this surpassingly beautiful plant.

Prices, same as Barberry, Japanese, on this page.

\section{Shrubs and Climbers}

\section{Clematis}

Henryi. Very large, creamy-white; vine a free grower and profuse bloomer.

JaCkmani. Wonderfully beautiful; large, deep violetpurple and very velvety; an abundant bloomer.

Madame Andre. Beautiful bright velvety red, large and handsome; a free bloomer.

JaPan, Paniculata. Flowers medium to small, pure white and deliciously perfumed. Vine hardy, a rapid, luxuriant grower and a profuse bloomer; blossoms in late summer. This is one of the very best climbing vines for covering porches, pillars, trellises, etc.

\begin{tabular}{c|c|c}
\hline Each & 100 & 1000 \\
\hline .50 & 40.00 & 300.00 \\
\hline
\end{tabular}

\section{Deutzia Lemoinii}

A perfectly hardy, dwarfish-growing, handsome shrub for the lawn. Beautiful, large, pure white flowers are borne in cone-shaped heads. Very desirable.

\begin{tabular}{c|c|c}
\hline Each & 100 & 1000 \\
\hline .35 & 25.00 & 200.00 \\
\hline
\end{tabular}

Hydrangea, Arborescens Sterilis

Hills of Snow

Bears snow-white blossoms of large size through a long blooming season. Fine foliage.

Prices, same as Clematis on this page.

\section{Lilac}

Assorted French Budded Varieties.

Prices, same as Clematis on this page.

\section{Lonicera Halleana}

Hall Japan Honeysuckle

Flowers white, changeable to yellow, and very fragrant; blooms constantly and holds its foliage very late.

\begin{tabular}{c|c|c}
\hline Each & 100 & 1000 \\
\cline { 1 - 2 } & 18.00 & 120.00 \\
\hline
\end{tabular}

\section{Philadelphus Gordonianus}

A late blooming, exceedingly handsome and pleasing shrub that bears, in great profusion, a pure white blossom, but which has no fragrance.

Prices, same as Deutzia Lemoinii on this page.

\section{Viburnum Plicatum \\ Japanese Snowball}

A valuable, hardy, erect, compact shrub. In early summer, it is a solid mass of large balls of snow-white flowers.

Prices, same as Clematis on this page.

\section{Weigela Rosea}

Deep rose-colored flowers; very desirable for borders, for grouping or single plants. Exceptionally handsome.

\begin{tabular}{c|c|c}
\hline Each & 100 & 1000 \\
\hline .40 & 30.00 & 240.00 \\
\hline
\end{tabular}

\section{Maple, Norway}

One of the very handsomest shade trees, and should be planted extensively everywhere. Not so quick in growth as Silver Leaf Maple, but is more beautiful and better. Has a round, spreading head, and transplants easily.

\begin{tabular}{l|c|c||c|c|c}
\hline \multicolumn{3}{|c|}{4 to 6 feet } & \multicolumn{3}{|c}{6 to 8 feet } \\
\hline Each & 100 & 1000 & Each & 100 & 1000 \\
\hline .50 & 45.00 & 240.00 & .70 & 65.00 & 360.00 \\
\hline \multicolumn{2}{|c||}{} & 8 to 10 feet & \multicolumn{3}{|c|}{10 to 12 feet } \\
\hline Each & 100 & 1000 & Each & 100 & 1000 \\
\hline 1.25 & 100.00 & & 1.50 & 130.00 & \\
\hline
\end{tabular}

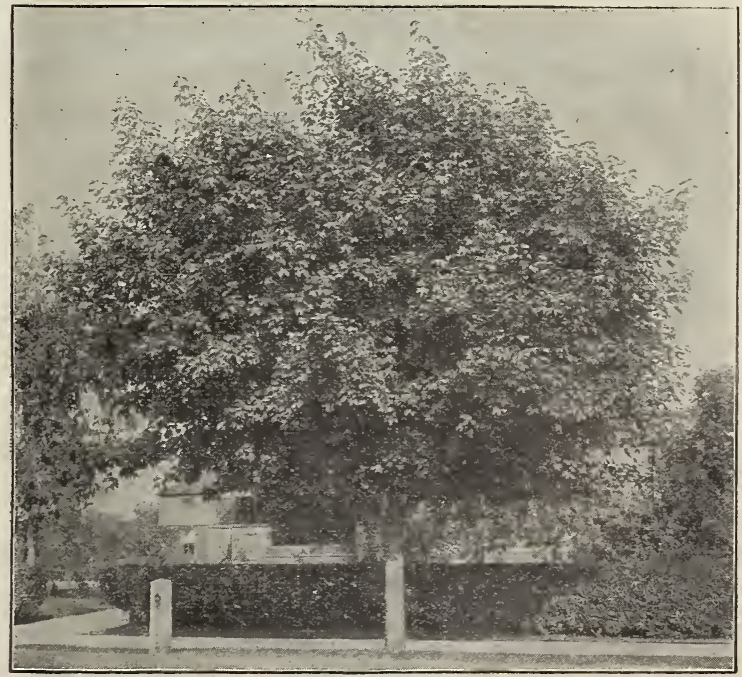

Norway Maple and Amoor River Privet-both unexcelled 


\section{Why You Should Plant One -Year Trees}

HOR many years Stark Bro's have advocated the planting of one-year trees, especially apple. Extensive experimental work conducted by us in our own orchards, as well as that carried on by horticulturists and orchardists in all parts of the country, has convinced us and many others that the one-year tree, given the care and attention it should have, will, in the long run, in most localities, make a better orchard tree than will a tree older than one year.

Adding to the knowledge gained from this experimental work, the result of the experience of orchardists in those famous fruit-growing valleys lying west of the Rocky Mountains, and in other fruit-growing regions, where a tree older than one year can scarcely be given away, the argument in favor of the one-ycar tree is complete.

Briefly, its merits are these:-

It is cheaper to buy - a fact of importance, since it lessens the planter's original investment.

It is planted more cheaply than the larger, bulkier tree, older than one year.

It withstands much better the shock of being taken up from the nursery, packing and shipping to some far-distant point, and transplanting to its permanent home in the orchard.

When transplanted in the orchard, it takes hold rapidly in its new surroundings; the roots become firmly established sooner and a healthy, vigorous growth sets in more quickly.

The future frame-work of the one-year tree may be placed exactly where the grower wishes it. Being in the form of a straight whip, with no branches, the one-year tree develops its branches after it is planted in its permanent place in the orchard, instead of in the nursery, as is the case with older trees. 'Thus by proper pruning, the head or frame-work of the tree can be made to take the shape or form desired by its owner, or to suit the conditions under which it must grow. This is a point of great importance and is one of the strongest arguments in favor of the one-year tree.

The one-year tree will, in most localities, come into bearing as young as the older tree. In many instances it has been known to bear earlier. In any locality it will live as long or longer, bear as much fruit and make a better orchard tree.

\section{Complimentary Sample One -Year Apple Trees}

GOR one dollar and fifty cents $(\$ 1.50)$ to cover the cost of packing and filling your order, we will send you, by express (express charges to be paid by you), ten (10) splendid, first-class oneyear-old apple trees, size 3 to 5 feet, of any one of the following five varieties:-
Jonathan
Grimes Golden
Stayman Wir
Black Ben

to 11 .

For descriptions of these varieties see pages 1

Note. On this special offer we cannot send you an assortment of these five varieties; your order must be for ten trees of just one of these varieties.

We will also include in the shipment without further cost to you, ten (10) fine, well-rooted, two-year-old grape vines-five (5) vines each of Niagara and Worden. These grape vines are from our branch grape nursery at Girard, Pa., which is in the very heart of the Chautauqua-Lake Erie Grape Belt, where the finest grape vines in the world are produced.

Remember, $\$ 1.50$ pays for the ten trees and the ten vines.

\section{Why this Special Offer is Made}

THAT you may see with your own eyes a fair sample of the magnificent one-year apple trees, as we grow them, and that you may test to your

\section{COUPON}

W. A. S. D

Stark Bro's, Louisiana, Mo.

I enclose $\$ 1.50$, for which please ship me in time for Spring planting 10 one-year

(Write name of variety here) apple trees, size 3 to 5 feet and 10 two-year grape vines ( 5 vines each of Niagara and Worden). I will pay the express charges.

Name

Shipping point

County State

Postoffice address

(If different from shipping point)

Ship by Express line

I expect to plant___ trees about 191 own satisfaction the genuine value of the one-year tree as compared with older trees - to prove to yourself that one-year trees are the ideal trees to form the best foundation for the commercial or home orchard.

The trees and vines here offered are in every way fully up to the Stark standard of tree excellence - strong, healthy, thrifty, well-rooted stock that will please you.

Cash must accompany order. Simply fill in coupon, pin remittance to it and mail to us. You will be happily surprised when the shipment reaches you.

Note. We have prepared a special four-page bulletin on this important subject of one-year apple trees, in which is embodied letters from many of the country's most experienced horticulturists in addition to the matter you have read on this page. It is also illustrated from photographs. Sent free on request. Ask for Bulletin No. 71 . 


\section{Special Educational Offer \\ We Pay the Freight}

TO educate tree planters in every section of the country to the wonderful quality and unusual high standard of one-year apple trees as we grow them, with every order for 100 or more one-year apple trees, size 3 to 5 feet, we will send absolutely free with our compliments 30 one-year peach trees, medium size, as follows:

10 Elberta, the old standard money-maker.

10 Krummel October, the best late peach.

10 assorted varieties of your own selection.

Cash to the full amount of your apple-tree order must be sent with order. Simply fill in the green order blank sent with this booklet. Attach remittance and mail to us.

This Special Educational Offer is good for Spring, 1911, orders only. It becomes void at the close of this Spring's shipping season.

Tell your friends and neighbors about this exceptional offer - they will want to know about it. More order blanks gladly furnished on request.

Don't put off ordering - do it at once. Even our liberal stock of peach and apple will not long stand the pressure this offer will bring. The whole country is tree-hungry this Spring and there are not enough trees to go around.

Orders on this Special Educational Offer will be booked in the order they are received. We positively cannot deviate from this rule. Shipments will be made as requested by customer.

Remember, we pay the freight. We also box and pack free: Complete satisfaction assured-safe arrival guaranteed.

\section{Demonstration Orchards of Stark Delicious on 6 per cent Co-operative Plan}

$\mathrm{W}^{\mathrm{E}}$ are prepared to supply on a proven and popular 6 per cent co-operative plan, trees for orchards of-Stark Delicious, Stark King David, Black Ben, Stayman Winesap, Jonathan and other money-making varieties of apple as well as Stark Early Elberta peach, etc. On this plan the orchard is given time to pay its own way. We can also furnish trees for orchards on an exceptionally liberal share-interest plan, on which the orchard pays for itself out of its profits.

By making these co-operative offers we emphasize our confidence in these leading varieties. They are the varieties that will make you the most money-we know it because we are willing to take our pay out of the profits they make you.

Write our Orchard Department for full information on these co-operative plans. Better act quickly for the Spring planting season will soon be here. And remember, an orchard planted this Spring will be a year nearer its profitable bearing age than if you delay till next Spring. 


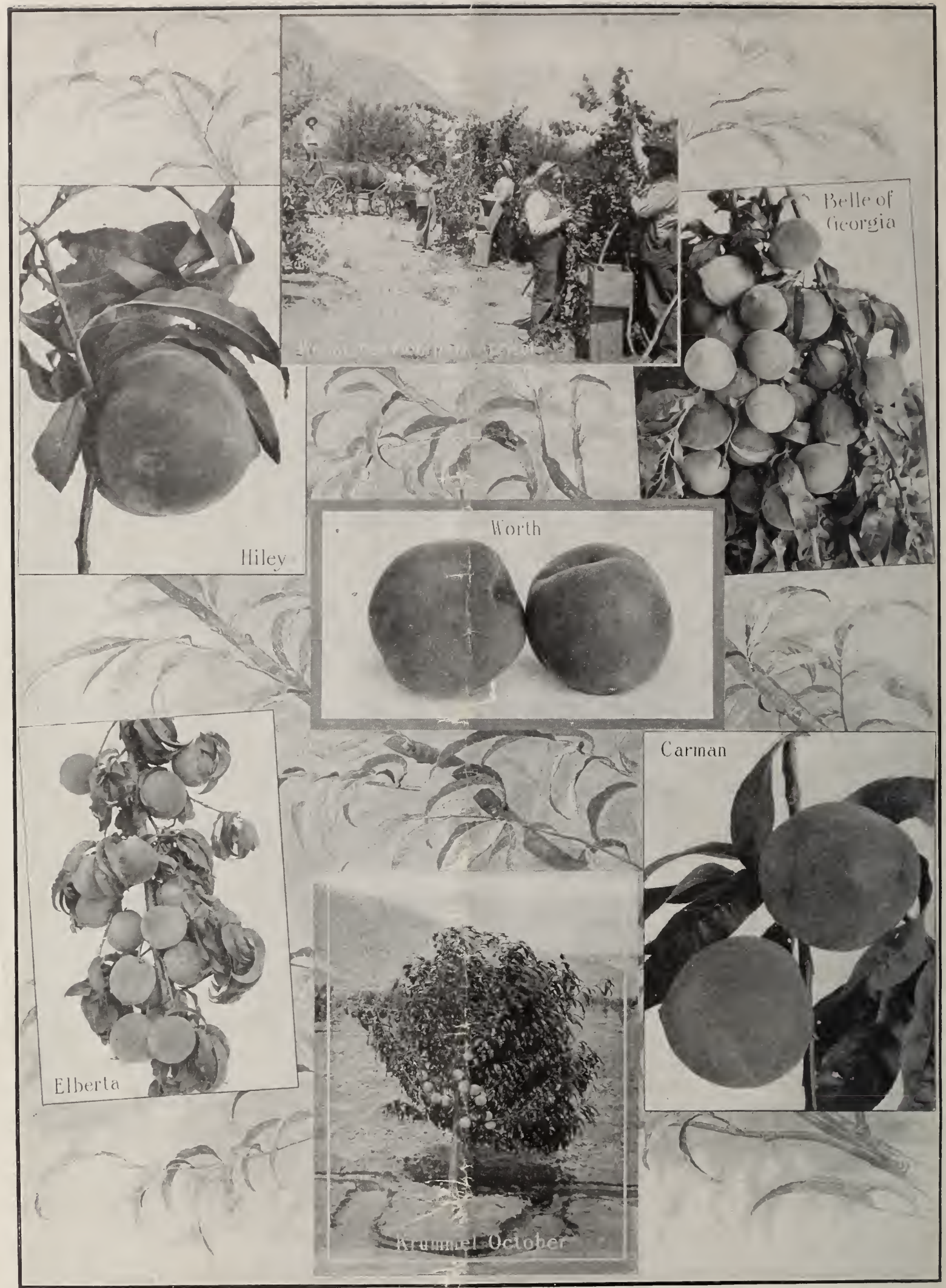

In every peachere are six splendid varieties of peach and one apricot of unusual merit. Peach growers everywhere will find any or all of them to be of the best of their respective seasons. 